Natural History Museum Library

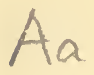

$?$ 

Bn

$\mathrm{Aa}$

0 . 


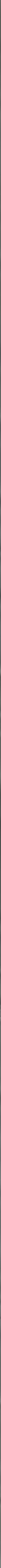





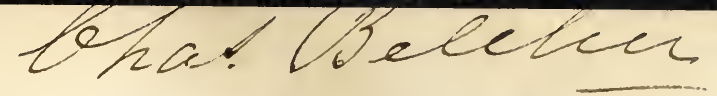

\section{SY NOPSIS}

\section{THE CONTENTS}

OF THE

\section{BRITISH MUSEUM.}

TWENTY-FIFTH EDITION.

\section{LONDON :}

RRINTED BY G. WOODFALL, ANGEL COURT, SKINNER STREET. 



\section{CONTENTS.}

Rooms

LOWER ROOMS.

Page

I.-XVI. Library of Printed Books.

UPPER FLOOR.

I. Miscellaneous Articles ....................................... 2

II. Ditto ......................................................... 7

III. Lansdowne Manuscripts........................................ 7

IV. Sloane and Birch Manuscripts................................ 8

V. Harleian Mantscripts ...................................... 9

VI. Harleian MSS. and Additions............................... 9

VII. Royal and Cottonian MSS .................................. 11

The Saloon, Minerals......................................... 12

VIII. Zoology .................................................. 57

IX. Petrifactions, or Fossil Remains of Animals and Vegetables 68

X. British Oryctognostic Collection.............................. 72

XI. British Zoology............................................... 72

\section{GALLERY.}

I. Terracottas ................................................ 81

II. Greek and Roman Sculptures................................ 91

III. Ditto.......................................................... 93

IV. Ditto................................................. 99

V. Roman Sepulchral Antiquities........................... 100

VI. Greek and Roman Sculptures............................ 105

VII. Roman Antiquities.............................................. 115

VIII. Egyptian Antiquities....................................... 117

IX. Egyptian Sculptures........................................ 120

X. Greek and Roman Sculptures................................ 130

XI. Coins and Medals............................................ 137

XII. Hamilton Collection of Greek Vases, \&c................... 141

XIII. Prints and Drawings........................................ 146

XIV. Phigalian Marbles, \&c....................................... 146

XV. Elgin Collection of Greek Sculptures, \&c................. 150

ANTE-ROOM.

Portland Vase, \&c................................................................... 139

REGULATIONS.................................................................... 185 
The Public are apprised that this Synopsis is merely intended for the use of Persons roho take a cursory view of the Museum. The following is a List of the more ample descriptions of several parts of the Collection. Those marked with an asterisli are progressive.

Descriptions of the Ancient Terracottas, by T. Combe, 1810,4to. 1812-1826, 4to.

* A Catalogue of the Greek Coins, by the same, 1814, 4to.

Anglo-Gallic Coins, by Edward Hawkins, 1826, 4to. Library of Printed Books, by H. Ellis and H. H. Baber, 1813-1819, 7 vol. 8vo.

Cottonian MSS. by J. Planta, 1802, fol.

Harleian MSS. by H. Wanley and R. Nares, 1808, 3 vol. fol.

MSS. of the King's Library, by Casley, 1734, 4 to. MSS. heretofore undescribed, by S. Ayscough, 1782, 2 vol. 4 to.

Lansdowne MSS. fol. by F. Douce and H. Ellis, 1819, fol.

MSS. formerly F. Hargrave's, Esq. by H. Ellis, 1818, 4 to.

A brief introductory Statement of the original Foundation and progressive Increase of the Establishment, may be had from the Messenger at the Museum. 


\title{
SYNOPSIS
}

\author{
OF THE
}

CON'TENTS OF THE BRITISH MUSEUM.

ON entering the gate of the Museum, a spacious quadrangle presents itself, with an Ionic colonnade on the south side, and the main building* on the north, the two wings being allotted for the dwellings of the officers. 'The architect, Peter Puget, a native of Marseilles, and an artist of the first eminence in his time, was sent over from Paris by Ralph, first Duke of Montagu, for the sole purpose of constructing this splendid mansion.

\section{GROUND FLOOR.}

The first floor, consisting of sixteen rooms, contains the Library of Printed Books. Strangers LibraRY of are not admitted into these apartments, as the

* The building measures 216 feet in length, and 57 in height, to the top of the cornice. 
mere sight of the outside of books cannot convey either instruction or amusement*.

The decorations of the great staircase have been lately restored. The paintings on the ceiling, representing Phaëton petitioning A pollo for leave to drive his chariot, are by Charles de la Fosse, who, in his time, was deemed one of the best colourists of the French School; and of whom there are many valuable performances in France, among which are the paintings on the cupola of the dome of the Invalids, which are ranked among the admiranda of Paris. The landscapes and architectural decorations are by James Rousseau, whose particular skill in perspective has at all times been held in high estimation.

\section{UPPER FLOOR.}

\section{FIRST ROOM.}

ROOMI. This room, in its present state of arrange. ment, contains Miscellaneous Collections.

In the table-cases in the middle of the room is deposited (as supplementary to the contents of Room IX.) a collection of fossil univalve shells, disposed according to Cuvier's arrangement. The table-cases in the windows contain objects relative to technical mineralogy, or

* An Alphabetical Catalogue of this Library was printed in the year 1787, in two volumes folio; but as great accessions have been obtained since that time, a new Edition is now published, in seven volumes 8 vo.

mineral 
mineral substances in a wrought state, with the ROOM I. scientific and familiar names affixed to them.

Case 1. Esquimaux dresses, implements and utensils, brought to England by Capt. Parry in 1823.

Cases 2 to 10. Miscellaneous specimens of minerals of considerable dimensions, with their names and localities affixed.

The remaining cases contain articles from the west coast of North America and the South Sea Islands.

Case 11. Fishing implements from Nootka Sound and Oonalashka: harpoons: lines made of sinews and of sea-weed (a species of Fucus), \&c.-Models of fishing-boats, \&c. : waterproof fishing-jackets, made of the intestines of the whale, from Nootka Sound.-Several caps of wood, representing heads of beasts : a bird's head of wood, ornamented with feathers, \&c.; a wooden coat of armour: birds made of wood, hollow, and containing stones, used as rattles; from Nootka and Oonalashka.

CASE 12. Warlike implements and various tools, clubs, adzes, \&c.: patoo-patoos of wood and bone, \&c. Various domestic utensils from the same part of the coast. A screen made of the feathers of an eagle: knives : spoons: eating-bowls: bread made of the root of the Cassada tree (a species of Jatropha), with an unprepared piece of the latter.-Caps of various shapes and colours; some with representations 
ROOM I. of the whale fishery: combs, \&c. from Nootka and Oonalashka.

CASE 13. Baskets made in various parts of the west coast of North America.-Mattings, \&c. The inner bark of a species of cypress (Cupressus thuyoides) in its different stages of preparation, for making mats, articles of dress, \&c. ; a garment made of this bark by the natives of Banks's Island.

Case 14. Specimens of sculpture: imitations of the human form; masks, \&c.

CASES 15 AND 16: Otaheite winter and summer cloths, made of the bark of the paper mulberry (Broussonetia), and variously dyed.-A mourning dress: a breast-plate made of feathers, \&c. used in war, \&c.

Case 17. Coarse mats for sails, \&c. Basketwork and cordage.-Ornamental mats made of a kind of flag; a dancing-apron, \&c. from Otaheite.

Case 18. Fishing implements. Various utensils made of a basaltic stone: rasps made of shagreen; wooden pillows; adzes of a kind of jade called axe-stone, \&c.-Ornamental carvings; cloth beater; plaited hair; tatooing instruments; a planting spade made of a fragment of a shield; nose flutes; a bread fruit.-Various stone adzes, hatchets, \&c.

Cases 19 and 20. Large cloaks; aprons; helmets; hats; distorted human figures, \&c. made of feathers.-From the Sandwich Islands. 
CASE 21. Various specimens of mats and ROOM I. cloths; gorgets made of red seeds, \&c.-Cordage; slings ; cloth beaters; hair for ornamental head-dresses._Fishing-hooks made of bones and shells; saws made of sharks' teeth; and other tools.-From the Sandwich Islands.

CASE 22. Articles of ornament: bracelets made of boars' tusks, and of tortoise-shell: assortment of shells and seeds, \&c.-Necklaces, and other ornaments. Coverings for the legs, composed of shells, seeds, and teeth, used in dancing: round mirrors made of a black slaty stone, which is wetted for use : quoits, weights, \&c.-From the Sandwich islands. Small cloaks, a head-dress, and other ornaments made of feathers:-a specimen of the species of creeper (Certhia vestiaria) which supplies the red feathers.-Fans: wooden bowls supported by grotesque figures for ornament.-Mostly from the Marquesas.

Case 23. Specimens of cloth, matting, and cordage.-Basket-work, plain and ornamented : screens for the sun.-Ornamental basket-work: various pouches : a dancing-dress made of the fibres of the bark of cocoa-nuts.-From the Friendly Islands.

Case 24. Fishing implements, hooks, and various nets: models of canoes: adzes made of shells: tatooing instruments: rasps, \&c.Various articles of ornament : necklaces made of shells, 
RoOM I. shells, seeds, \&c. : combs : bracelets : kernels of a nut which, when burnt, yields a strong light.Aprons and other ornaments, made of the thighbones of a small bird: nasal flutes : fly-flaps, a shuttle, \&c.-Various Cava bowls of wood curiously: carved: some earthen vessels, \&c.From the Friendly Islands.

CASE 25. Various specimens of matting and cordage, mostly made of the New Zealand hemp (Phormium tenax).-Sundry woven articles: belts, \&c.-Fishing nets : hooks, cordage, \&c. From New Zealand.

CASE 26. Articles of ornament: combs: necklaces, \&zc.-Specimens of carving in wood and bone: pipes, and other musical wind instruments.-Warlike instruments : conchs used in war : clubs: saws made of sharks' teeth for dissecting the bodies of slain enemies: two human hands, being parts of the body of a slain enemy. Tools of various kinds, \&c.-Various wooden boxes ornamented with carvings. - Boat scoops, \&c.-From New Zealand.

Over the Cases 11 to 14. Various missile weapons from different parts of the west coast of North America and the islands of the South Sea: harpoons, javelins, spears : a wooden shield: also various calabashes, some inclosed in wickerwork: a sledge from Baffin's Bay.

Over the Cases 18 to 20. Bows, arrows, quivers, drums, \&c.

Round 
Round the door opposite the Entrance. ROOM I. Various sorts of plain and carved clubs, maces, \&c.

Over Case 21. A large Cava bowl: wooden pillows.

Over Case 23. A canoe composed of many pieces of wood sewed together, from Queen Charlotte's Island: various kinds of paddles, \&c.

Over the Cases 25 and 26. A large wooden drum with lateral opening, made of the trunk of a tree: a wooden box, \&c.

\section{SECOND ROOM.}

This room contains miscellaneous objects ROOM II. under arrangement.

\section{THIRD ROOM.}

LANSDOWNE LIBRARY OF MANUSCRIPTS.

This library, acquired in 1807 by a vote of Parliament, is not yet finally arranged. It consists of 1245 volumes (exclusive of Rolls and Charters), of which a hundred and twenty-two contain an ample collection of Lord Burleigh's State Papers, many of them originals: more than fifty volumes contain Sir Julius Cæsar's papers, all relative to the history of the time of Queen Elizabeth and King James I. : a hundred and seven volumes of historical collections of $\mathrm{Dr}$. White Kennet, Bishop of Peterborough : a considerable number of original royal and noble letters and papers: and a great store of histori-

ROOM III.

Lansdowne MSS. 
ROOM III. cal, juridical, biographical, heraldical, and miscellaneous collections *

\section{FOURTH ROOM.}

\section{SLOANEAN AND BIRCH'S COLLECTIONS OF MANUSCRIPTS.}

ROOM IV.

Three Presses

between the

Windows.

Birch's MSS.

Presses III.-

XXX.

Sloanean MSS.

Dr. Birch, consisting of three hundred and thirtyseven volumes, chiefly on history, biography, divinity, and literature.

Sir Hans Sloane's library of MSS., consisting of 4100 volumes, principally on physic, natural history, and natural philosophy. It also contains Kæmpfer's MSS. ; several journals of voyages; and some Oriental MSS.

In a recess, within this room, are placed $\mathrm{Mr}$. Hashed's and some other collections of Oriental MSS.; and a collection of MSS. and Rolls, consisting of sixty-two articles relating to Kent, purchased of Mr. Hasted.

Over the chimney is a drawing of the Palace of Columna, near Moscow, which belonged to the Czars of Moscovy; it was built of wood, and is now demolished: presented by the Honourable Percy Wyndham t.

* A new Catalogue of this Library was completed and published in 1819, under the direction and at the expense of the Commissioners upon Records of the Kingdom.

† A Catalogue of the contents of this Room, and of most of the additional acquisitions in the Fifth Room, compiled by the Rev. S. Ayscough, was printed in the year 1772, in two volumes quarto. 


\section{FIFTH ROOM.}

\section{HARLEIAN LIBRARY OF MANUSCRIPTS.}

The greatest part of the Harleian Library of Room v. Manuscripts is deposited in this Room, which is at present appropriated for the use of the readers.

\section{SIXTH ROOM.}

The remainder of the Harleian Library of ROom vi. Manuscripts is deposited in this room*.

MSS.

Also Many additions By GIFT, Bequest, and PURCHASE; among which are particularly remarkable,

Fifty-seven volumes containing a series of Public Acts relating to the history and government of England, from the year 1115 to 1608, collected by Thomas Rymer, but not printed in his Fœdera; and sixty-four volumes of Rolls of Parliament; the whole ordered by the House of Lords to be deposited in the Museum.

A collection in forty-seven volumes, relating to the History of Ireland; presented by the Rev. Jeremiah Milles, Dean of Exeter.

Forty-three volumes of Icelandic Manuscripts; presented, with a much more numerous collection of printed books, by the Right Hon. Sir Joseph Banks, Bart. K.B.

* A Catalogue of these MSS. was printed in the year 1759, in two volumes folio: but the latter part of it was found so defective, that it became necessary to have it corrected and enlarged. This improved work was completed in 1809, and, with copious Indexes, forms four volumes folio.

Forty-one 
Room vI. Forty-one volumes containing the decisions MSS. of the Commissioners for settling the City estates after the fire of London: presented by Thomas Cowper, Esq.

Twenty-four volumes relating to the history of Music, which, together with a considerable collection of printed books on the same subject, were bequeathed by Sir John Hawkins.

Twenty-seven volumes of Music, chiefly mottets, and other church music, by old composers (Prenestini, Palestrina, Pergolese, Stefiani, Handel, \&c.); bequeathed by James Mathias, Esq.

Thirty-eight volumes of manuscripts, and nine of drawings, being a copious collection towards a topography and history of the county of Sussex; bequeathed by Sir William Burrell. To these have recently been added by the donation of John Fuller, Esq. of Rose Hill, the collec. tions for the same county, made in concurrence with Sir Wm. Burrell, by the late Rev. William Hayley of Brightling.

Forty-four volumes, thirty-two of which contain an obituary kept by the donor, the rest being a collection of autographs, original war. rants, and other documents, catalogues of portraits, \&c.; bequeathed, together with a considerable library of printed books, by Sir William Musgrave, Bart.

A numerous collection of manuscripts, chiefly relating to the county and university of Cambridge, bequeathed by the Rev. Wm. Cole, M.A. 
In the presses $\frac{1}{2}$ and XVI. are two rolls of the ROOM VI. Pentateuch on vellum, the former of considerMSS. able antiquity, and the latter much more recent: this latter, together with a considerable number of Hebrew MSS. and printed books, was presented by Solomon Da Costa, Esq.

Against the press $\frac{1}{2}$ hang three specimens of minute writing, forming the portraits of Queen Anne, Prince George of Denmark, and the Duke of Gloucester their son.

Against the press XVIII. hangs an original deed in Latin, written on papyrus, being a conveyance of some land to a monastery; dated Ravenna, $\mathrm{A}^{0} 572$, bought at the sale of the Pinelli library. And opposite to it is a large specimen of the reed (Cyperus Papyrus) of which that kind of paper is made.

In the second window hangs an Italian note to Sir William Hamilton, written on modern papy. rus, explaining the mode of preparing it.

\section{SEVENTH ROOM.}

THE ROYAL LIBRARY OF MANUSCRIPTS. Deposited in XXXIII Presses.

THE COTTONIAN LIBRARY OF MANUSCRIPTS.

Deposited in XXI Presses.

These two libraries are not classed in a strict ROOM VII. scientific order*.

$\overline{\mathrm{MSS}}$.

* Or the King's Library, a Catalogue compiled by Mr. David Casley was printed in the year 1734 , in quarto: and of the Cottonian Li- 
ROon viI. In the press under No. XIX. of the Cottonian

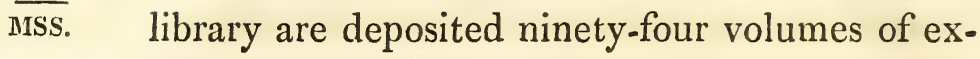
tracts, transcripts, and notes, chiefly relating to the Exchequer, collected by Thomas Madox, Esq., historiographer to Queen Anne and King George I., and bequeathed by his widow, as an addition to the Cottonian library.

On the table, in a glazed frame, is the original of the Magna Charta, belonging to the Cottonian library; and on the side of it is a fac-simile engraving of it, by Pine.-Against press XXI. of the Cottonian library is the original of the articles preparatory to the signing of the Great Charter, perfect, with the seal: presented in 1769 by Earl Stanhope.

\section{THE SALOON.}

SALOON. This apartment contains the principal Collection of Minerals of the Museum, systematically arranged, the more characteristic specimens being deposited in the table-cases, and the re. mainder in the drawers underneath. In the arrangement of this collection, a natural order founded on external characters has been followed : not, however, without consulting the che-

brary, there are no less than three Catalogues extant : the first by Dr. Thomas Smith, printed 1696, folio ; the second, being an attempt towards a classical arrangement, printed in 1777, octavo; and the third, improved and considerably enlarged by Mr. Planta, printed by $\mathrm{His}$ Majesty's command in the year 1802, folio. 
mical composition of the substances, so far as SALOON. convenience would admit. Each of the glazed Nat. Hist. table-cases has its number inscribed on the upper part of the middle square of glass.

Case 1 contains the combustible substances, among which may be particularized the different varieties of bitumen, from the fluid naphtha to the solid jet (pitch coal of Werner) and the mineral caoutchouc from Derbyshire. (See British Collection: Derbyshire.) With these is placed an inflammable fossil substance found by Humboldt in South America, where it is called dapèche, which has several of the properties of the common caoutchouc or India rubber; also the retin. asphaltum or retinite, found at Bovey, and that from Wildshut and Bergen in Bavaria; the peculiar resinous substance discovered in digging the tunnel at Highgate, \&c. - Amber, the yellow and white varieties: fragments inclosing insects. - Sulphur, crystallized and massive, with selenite, sulphate of strontian, \&c.; the same found sublimed near the craters of volcanos.-Graphite, commonly called black lead, massive, disseminated in porcelain earth, \&c. (See British Collection: Cumberland.)-A few specimens of black coal.-Brown coal, to which belongs the well known Bovey coal.-Dysodile, or papyraceous brown coal. Among the specimens of anthracite or kohlenblende (to which may be referred the Kilkenny coal) is a specimen from Kongsberg in Norway, with native silver. 
SALOON.

Case 2. The diamond, though combustible, is NAT. HIST. by common consent considered as the first of precious stones: among the specimens selected to exemplify its crystalline forms, are the primitive regular octahedron; the same with solid angles truncated; with edges truncated, forming the passage into the rhomboidal dodecahedron; varieties of the latter, giving rise to the six-sided prismatic and the tetrahedral forms; cubes with truncated and bevilled edges; various hemitropic crystals or macles of diamonds, \&c. With these are also placed specimens of the alluvial rocks in which the diamonds occur in the East Indies and in Brasil.-Zircon: to which belong the common jargon of various colours, and the orangecoloured, considered by some as the true hyacinth, from Auvergne, Chili, \&c.; also the variety called zirconite, from Friedrichsvärn in Norway, im. bedded in syenite, a rock composed of feldspar and hornblende-Corundum: which comprehends the precious stones commonly called oriental gems (thesapphire, ruby, oriental amethyst, oriental topaz, oriental emerald), of the crystal. line forms of which the principal modifications are here deposited; and the common or imperfect corundum from Bengal, Mysore, China (the diamant-spath of Werner), Lapland, Piedmont, \&c. -As appendix to these are added, the fibrolite (bournonite of Lucas), one of the concomitant substances of common corundum; and the emery which owes its hardness and consequent useful- 
ness in polishing to an admixture of blue corunSALOON. dum. Between the common corundum of this Nat. Hrst. and the feldspar of the contiguous opposite tablecase, is placed the andalusite, which was first considered as a congener of the former, and afterwards referred to the latter (as feldspath apyre), but appears to be distinct from both.

Cases 3, 4. Among the many varieties of spinel we have the ceylonite or pleonaste, by some still considered as a distinct species, and the blue spinel from Aker in Südermania. Another substance nearly related to this species, is the auto= molite (thespinelle zincifère of Haüy) from Fahlun in Sweden, and North America.-Among the specimens of chrysoberyl or cymophane may be noticed the North American variety, in its matrix of quartz and feldspar with small trapezoïdal garnets. - Kyanite or disthène, massive, in separate crystals and imbedded, with grenatite, \&c. ; also in small polished pieces, which are sometimes mistaken for sapphires.-Emerald and beryl: several crystals of the South American emerald, insulated and in their matrix; emeralds from Salzburg. Beryls of various colours, the most common of which is the variety called aquamarine : the fine groups of these, found in ferruginous loam at Nerchinsk and Adontchelong in Siberia, are very remarkable; large crystals of emerald or beryl from Limoges in France, and from Rabenstein in Bavaria, the latter accompanied by columbium.-Near the beryl is placed 
SALOON. placed the euclase, a rare crystallized mineral sub. Nat. Hist stance, discovered by Dombey, in Peru, and which has also lately been found in the chlorite slate at Capao, near Villaricca in Brasil.-The pycnile, referred by Werner to the beryl, under the name of shorlous beryl, and considered as a variety of topaz by Haüy. The pyrophysalite, from Fahlun in Sweden, described by the same crystallographer as a variety of topaz.-A series of crystals of Saxon, Brasilian, and Siberian topazes, among which there are several new modifications; Saxon varieties, imbedded in the topaz rock, an aggregate of topaz, shorl, quartz, and sometimes mica.-These cases also contain the tourmaline and common shorl. Among the varieties of the former may be specified the rubellite, also called siberite (tourmaline apyre of Haüy), a remarkable specimen of which, both with regard to form and volume, is here preserved: it was presented by the King of Ava to the late Colonel Symes, when on an embassy to that country, and afterwards deposited by the latter in Mr. Greville's collection. Other red and blue varieties from Siberia, and from Massachusets in North Ame. rica; the flesh coloured tourmaline from Rosena in Moravia (which is by some considered as a variety of pycnite), \&c.-Varieties of common shorl.-In CASE 4, and the adjoining opposite compartment, begin the substances belonging to the species of quartz.-Rock crystal: various modifications of its crystalline forms : small dodecahedral 
decahedral and other crystals, known by the rivial names of Gibraltar diamonds, Bristol diaSALOON, Nat. Hist. monds, \&c.; varieties of colour according to which the crystals obtain the familiar denominations of smoky topaz or morion, cairngorm, citrine, \&c.; specimens of rock crystal, enclosing various substances, such as rutile, brown ironstone, micaceousiron, needle antimony, actinote, asbest, chlorite, \&c. groups of rock crystal.Amethyst quartz of various tints, in grouped crystals; nodule lined with crystals of amethyst and cross-stone or harmotome, from Oberstein, \&cc.

CASE 5. Common quartz: among the specimens of this widely diffused substance, which offers such great variety in its external aspect, the more remarkable are those of hacked, corroded and cellular quartz from Schemnitz, as also the pseudomorphous or supposititious crystals, principally derived from modifications of calcareous and fluor spars; and, with regard to colour, the red quartz crystals from Compostella, imbedded in gypsum, and known bythe name of hyacinths of Compostella; the blue quartz or siderile from Salzburg. - Among the other varieties of quartz is the rose or mille quartz, which occurs only massive, and the prase, which appears to be an intimate mixture of common quartz and actinote.-Fibrous quartz.-In this table-case are also deposited some varieties of the cat's eye (mostly from Ceylon); a substance generally referred to the quartz family. 
Saloon. Case 6. Besides some specimens of substances NaT. HIst. related to common quartz, such as the avanturino quartz, the flexible sandstone from Brasil, and the iron flint (a substance in which oxide of iron exists in chemical union with silica), this case contains varieties of the stalagmitical quartz, also called quartz sinter. The most remarkable among these are the siliceous concretions deposited by the celebrated hot spring in Iceland, the Geyser, one variety of which is called siliceous tuf, the other calcedonic sinter. A nother variety of it is the pearl sinter from Santa Fiora in Tuscany (whence it has obtained the name of Fiorite), and from the island of Ischia. To this may also be referred the ceraunian sinter, or those enigmatical siliceous tubes which were first found in the sands of the Senner heath, in the county of Lippe (where, from their supposed origin, they are called lightning tubes, from which name those of fulgurite, ceraunian sinter, astraphyalite, are derived), and subsequently, under similar circumstances, at Drigg, on the coast of Cumberland [see British Coll.], near Konigsberg, at Halle on the Saale, and latterly near Dibbla in the Tuarick country, Africa, which is the locality of the specimens here deposited.-The hyalite is placed here, as a mineral related both to stalagmitical quartz and calcedony. - The rest of this table-case and the greater part of the following are occupied by calcedonic substances. Among the specimens 
of common calcedony, the most remarkable are, the smalt-blue variety from Felsobanya in TranSALOON. Nat. Hist. sylvania, crystallized in cubes; the branched and stalactical calcedony from Iceland, \&c.; the botryoïdal from Ferroe; nodules including water (enhydrites) from Monte Berico, near Vicenza, where they occur in volcanic rocks: cut and polished pieces of calcedony, with black and red dendritic and other figures, commonly called mocha stones; varieties with white, brown, and black, straight or curved lines; onyx, sardonyx, \&c.

Case 7. Calcedonic substances continued. Among these are various specimens of the red and yellowish varieties of calcedony, called car. nelian: striped carnelians, \&c.-Heliotrope, an intimate mixture of calcedony and green earth, which, when containing disseminated particles of red jasper, is commonly termed blood-stone. -The beautiful and much esteemed variety of calcedony, called chrysoprase: it has hitherto been only found at Kosemütz in Silesia, accompanied by a siliceous earthy substance called pimelite, which, like the chrysoprase, owes its green colour to oxide of nickel.-By way of appendix to the calcedonic substances, are added a fer specimens of the less compound varieties of agates, in which common calcedony, carnelian, and heliotrope respectively form the predominant ingredients. [See also Room I. Table 2.]-Of fint, a well known mineral sub- 
SALONN. stance, several interesting varieties are deposited NAT. HIst. in this case.

CASE 8 contains principally opaline substances, viz. specimens of the noble opal, which owes its beautiful play of colours to a multiplicity of imperceptible fissures in its interior; the sun or fire opal; the common opal, a translucent white variety of which, appearing yellow or red when held between the eye and the light, is called girasol; the semi-opal, agreeing in its principal characters with the common; specimens of those varieties which, having the property of becoming transparent when immersed in water, are called hydrophanes, and vulgarly oculus mundi; rood-opal, or opalised wood; jasp-opal, referred by some authors to jasper; the menilite, called also liver-opal, found at Menil-Montant, near Paris, in a bed of adhesive slate, a specimen of which is added. Some varieties of cacholong may likewise be referred to the opal tribe.-The remainder of this case is occupied by the siliceous substance called hornstone, divided into the conchoidal and splintery varieties; among these are the remarkable pseudomorphous crystals from Schneeberg in Saxony, derived from various modifications of calcareous spar, and generally referred to conchoidal hornstone; also some beautiful specimens of wood converted into hornstone, being the wood-stone of Werner; hornstone balls from Haunstadt in Bavaria. Flinty slate, \&c. 
CASE 9. In this case are deposited (besides SALOON. the specimens of rock crystals continued from Nat. Hist. the opposite compartment of the table-case) the different varieties or subspecies of jasper sucli as they are enumerated by Werner, viz. the globular or Egyptian jasper, found chiefly near Cairo, in rounded pieces, which appear not to owe their form to rolling, but to be original and produced by infiltration; the ribbon jasper, or striped jasper, the finest varieties of which are found in Siberia; the variously-tinted common jasper; the agate jasper, found only in agate veins; the porcelain jasper, which is produced by the action of subterraneous fire on clay slate. Also the substances constituting the obsidian tribe, such as the pitch-stone, which is often confounded with semi-opal; - the pearl-stone, so called from its colour and the small globular concretions of which it is composed; - the $o b$ sidian, a remarkable variety of which is that found in globular pieces, at Ochotzk in Siberia, near the small river Marekanka, from which it has obtained the name of marekanite; pumice, which is not in all cases of volcanic origin. Near these substances are placed some specimens of the mineral called iolite or pelioma, as also dichroite, from its exhibiting two different colours when viewed in different positions; to this belongs the substance from Orayervi in Finland, called steinheilite. 
SAlOON. CASE 10. This case contains zeolitic subNAT. HIst. stances, viz. several varieties of scolicite and of mesotype, among the specimens of which may be particularized those with perfect prismaticacicular crystals (needle-stone of Werner); the delicately fibrous varieties; the red compact variety, by some called crocalite, \&c. Also the natrolite of Klaproth, of which a few specimens are added, is a variety of mesotype.-Stilbite, mostly crystallized: among the coloured varieties is the red from Fassa (fassaite).-Apophyllite, some varieties of which have been mistaken for mesotype and stilbite.-Analcime, among the crystallized varieties of which are remarkably large specimens of the trapezoïdal modification.-Chabasite, or chabasie, in groups of primitive rhombohedral and modified crystals.

CASE 11. Continuation of zeolitic substances: - prehnite, crystallized and massive, the grassgreen variety of which, discovered in South Africa by the Abbé Rochon, has been mistaken for chrysolite, chrysoprase, and even emerald. To this belongs also the koupholite of Vauquelin, and probably also the karpholite of Werner. The substance known by the name of Chinese jade (or stone You, see Room I. table 5.) may perhaps likewise be referred to prehnite.-Harmotome, or cross stone, both in simple and cruciform crystals, from Oberstein, Strontian, and 
Andreasberg in the Hartz, which last locality has produced to this substance the names of NAT. Hist. andreolite and hercinite.-Among those sub. stances deposited in this case which are in some respects related to zeolitic minerals, may be observed the lazulite or lapis lazuli, which furnishes the valuable pigment known by the name of ultramarine; and the haüyne, a mineral so named in honour of the late celebrated French crystallographer. Intermediate between the zeolitic substances and feldspar, are placed some mineral species which cannot be referred to either of these tribes: among them are the meionite and sommite, both from Vesuvius; the scapolite, a Norwegian mineral, of which several varieties are known under different names, such as the vitreous scapolite, the compact and the common scapolite (called also wernerite, after the late illustrious professor of Freiberg); the talc-like scapolite (micarelle of some authors), \&c. ; the bergmannite and the fettstein of Werner are related to them.-Distinct from these is the sodalite, from Greenland, and a new concomitant substance, the eudialyte of Stromeyer, composed chiefly of silica, zirconia, and soda.-In this table-case also begins the suite of specimens of feldspar, which is continued in the next case; specimens of compact feldspar, among which are, the red variety from Sweden, frequently mistaken for hornstone; the reissstein of Wer- 
SALOON. ner; the feldspath compacte tenace of Haüy, NaT. HIst. which is the same as the jade of Saussure, called by some saussurite, \&c.

CASE 12. In this glass-case are deposited the different varieties of the Labrador feldspar, the naker-feldspar, or adularia, and the common feldspar.-Among the specimens of Labrador feldspar (more properly called opalescent feldspar, being remarkable for the beautiful play of colours which it exhibits) are several from the transition syenite of Laurwig in Norway.-The adularia (which stands in the same relation to common feldspar as rock crystal to common quartz) is principally found on Mount St. Gothard, but not in the valley of Adula, from which its name is incorrectly derived: this variety when cut en cabochon, (see Room I. Table 5.) is commonly called moon-stone; modifications of crystals of this variety.-Common feldspar, variously crystallized and massive, among the latter of which may be particularized the fine green variety from Siberia, called amazon. stone; feldspar with imbedded fragments of quartz (graphic stone) from Siberia, \&c.-To these are added a few specimens of disintegrated feldspar, which passes into porcelain earth. - The chiastolite or macle, placed in this table, is referred by Werner to feldspar, under the name of hollow spar.-Icespar.-Petalite and spodumen or triphane, substances in which lithi- 
um, a new mineral alkali, has been discovered. -Indianite, one of the matrices of the common SALOON. NaT. HIST. corundum of the Carnatic. - Albile.

CASE 13 is principally appropriated to the substances of the garnet tribe. Among the more remarkable varieties of the noble garnet is that in curved-lamellar concretions, found massive in Greenland.-The pyrope, or Bohemian garnet, in rounded grains, \&c.-The common garnet, the predominant colours of which are brown and green : among these may be mentioned the variety which, from its resemblance to resin, is called colophonite. To this also belongs the "elegant variety from Kamschatka, denominated grossular, on account of the resemblance which its separate crystals bear to a gooseberry.-Trapezoïdal and emarginated crystals of the black garnets, called melanite, found particularly in the neighbourhood of Frascati.-The allochroite, also called splintery garnet, from Drammen in Norway. - The aplome, whose dodecahedral crystals differ from those of the garnet in being streaked in the direction of the short diagonal of their rhomboidal planes. - The cinnamonstone (essonite of Haüy) from Ceylon, a mineral which was supposed to contain zirconia, till a more accurate analysis proved it to be a substance nearly allied to garnet and vesuvian: some polished pieces of the same, being the true hyacinth.-Among the specimens of vesuvian or idocrase, the more conspicuous are the large beautiful 
SALOON. beautiful crystals (the unibinaire of Haüy) disNaT. HIst. covered by Laxmann on the banks of the Vilui in Kamschatka, imbedded in a steatitic rock; those from Vesuvius, where this substance occurs accompanied by other volcanic ejections, have, in Italy, obtained the appellation of volcanic gems, hyacinths, and chrysolites.-Gehlenite.-In this case, though not very closely allied to the garnet tribe, is also deposited the staurolite (called also grenatite and cross-stone): besides several varieties of the cruciform and other crystals from Britany, we have modifications of the simple crystals in mica-slate from St. Gothard, accompanied by prisms of kyanite perfectly similar to those of the staurolite, and sometimes longitudinally grown together with them.

CaSe 14. The contents of this table-case are :-chrysolite and olivine (péridot of Haüy), the former crystallized, and in cut and polished pieces; the latter as grains, in basaltic rocks and separate: to which is added some of the olivine-like substance found in the cells of the Siberian meteoric iron (CAse 49).- The substances which have been described under the names of thallite, arendalite, akantikone, delphinite, \&c. are Haüy's epidote, and Werner's pistacite : of which several specimens are deposited in this case. Among these is also the violet manganesiferous epidote, referred by some to the ores of manganese.-Zoisite.-Axinite, variously crys. tallized, 
tallized, from Dauphiné, \&c.-The pyroxene tribe, comprising the augite, in separate crystals SALOON. NAT. Hist. and imbedded in Vesuvian lava, together with groups of well defined crystals from Arendahl in Norway, where this substance occurs in primitive rocks, and the granular augite or coccolite; the varieties of diopside (now pyroxene) called alalite and mussite; the salite or malacolite, a species perfectly distinct from the common augite or pyroxene; the fusible augite called euchysiderite.-Jeffersonite, a mineral from New York, related to pyroxene. The remaining substances in this case relate to the hornblende-or amphibolic minerals, which are continued in the two next cases: basaltic hornblende from Vesuvius, common hornblende, \&c.

CASE 15 AND PART of 16. Continuation of amphibolic minerals. Only a few specimens of that widely diffused substance, the common hornblende, could be deposited in this part of the collection.-Between this and the substance called diallagite, or diallage (in the adjoining and opposite case, No. 16), are placed the hypersthène of Haüy (Labrador hornblende of Werner) and the anthophyllite, a substance from Kongsberg in Norway, nearly allied to them.The actinolite or strahlstein (of which we have the common, glassy, and fibrous varieties) likewise passes into substances contained in the opposite glass-case, especially the amianthoide from Oisans, and the fibrous actinote, which is closely 
SALOON. closely allied to some varieties of common asbest. NaT. HIst. - The tremolite (formerly grammatite of Haüy, but now considered as a variety only of amphibole or hornblende): among the specimens of this substance are, the fine fibrous variety, not unlike in appearance to sume varieties of asbest in the opposite glass-case; glassy tremolite in dolomite and granular limestone (see the adjoining table-case, No. 21). - The rhoticite, a mineral, which, according to Werner, is intermediate between tremolite and kyanite, but probably is the same with the latter.

Case 16. Asbest and amianth, with other related substances : among these may be observed specimens illustrative of the transition from a very close to a loose-fibrous structure; various specimens of the flexible asbest or amianth, with some antique incombustible cloth, paper, \&c. made of it; the varieties called mountain wood, mountain cork, or nectic asbest, \&c. separate, and in combination with other substances.-As bordering on the varieties of actinote in the adjoining opposite glass-case, we have here the diallagite (diallage), the green variety of which, called also smaragdite, is considered by Werner as a granular variety of actinote: in combination with saussurite (a variety of compact feldspar) it constitutes the verde di Corsica. Another variety is called omphacite by Werner.-In its vicinity is also placed the axe-stone, or Punamu-stone, thus called after one of the New Zealand Islands, where 
where the natives make hatchets, idols, \&c. of it: 'SALOON. it is generally considered as a variety of jade.

NAT. Hist.

Case 17. This case is occupied by the micaceous and talcose substances. Among the varieties of mica or glimmer, may be specified those that exhibit perfectly transparent crystals; the beautiful red and yellow varieties, together with those of a metallic lustre: diverging-radiated mica, \&c.-Pinite (micarelle of Kirwan). -Lepidolite; with which is placed a specimen of what is considered as compact lepidolite.Intermediate between mica and talc, is the chlorite, among the varieties of which are the earthy, common, foliated, and the slaty: the last of these, with octahedral magnetic iron-stone, bitterspar, \&c. - Of talc we have the common or Venetian (which enters the composition of cosmetics) and the indurated talc: to the former of these may also be referred the beautiful green variety from Siberia, composed of distinct groups of small diverging-radiated laminæ.-Potstone, or ollite, the lapis comensis of the ancients, from Como in the Milanese, where it is turned on the lathe into most durable culinary vessels.-In this case is also placed a substance from New York, which has very much the appearance of white laminar talc, but is a hydrate of magnesia.

CASE 18 contains steatitic substances.-Noble serpentine, which, in combination with primitive limestone, constitutes the marmo rerde antico; common serpentine, among the varieties of which are best known those from Bareuth and from 
SALOON. Zöblitz in Saxony, where they are manufactured NAT. HIsT. into vases and various other articles; serpentine with garnets, magnetic ironstone, asbest, slaty talc, \&c.-Triclasite or fahlunite, from Sweden and Greenland.-Varieties of steatite, among which the most remarkable are, that of a yellowish-green colour from Greenland, and that from Göpfersgrün in Bareuth, with small crystals of other mineral substances, converted into, and forming part of, the massive steatite.-To these are added some substances which are allied to the preceding, though differing from them with regard to their chemical composition; such as the agalmatolite of Klaproth (bildstein of Werner, talc glaphique or Haüy), employed by the Chinese for carving images, vessels, \&c.-The keffekil or meerschaum, from Natolia, of which pipe bowls are made; and a related substance, called keffekilite by Dr. Fischer, who discovered it in the Crimea.-Lithomarge, the more remarkable varieties of which are, that of a reddish yellow colour, from Rochlitz, in porphyry; the fine purplish blue variety from Planitz, called terra miraculosa Saxonica by old writers.-Fuller's earth.-Bole; green earth, \&c.

Cases 19 and 20. In these and the three following table-cases are deposited the various carbonates of lime.-Crystallized carbonate of lime or calcareous spar; specimens illustrative of the cleavage, supernumerary joints, colour, \&c.; primitive rhombohedron; various secondary rhombohedrons: among these the most common, 
but not the least striking, is the inverse rhombohedron, so called from being as it were an inSALOON. version of the primitive; the same with a considerable admixture of quartz, commonly called crystallized sandstone of Fontainebleau. Prismatic andpyramidal modifications of the same, among the former of which are the beautiful varieties from the Hartz, Salzburg, \&c.*

Case 21. The same continued: this case contains specimens of the lamellated varieties of carbonate of lime, called slate-spar and aphrite; tabular spar with garnets and cinnamon stone, and some of the Vesuvian varieties of the same, to which the name of wollastonite has been given by the Cav. Monticelli; granular and compact limestone (marbles); massive magnesian limestone, called dolomite, and (contiguous to it, in the opposite case) the crystallized magnesian limestone, called bitterspar, in chlorite slate; a variety of the same called tharandite, \&c.- The substances called gurhovian, from Gurhof in Lower Austria : and conite, composed of the carbonates of lime and magnesia.-Fibrous limestone, the finest varieties of which are those from Cumberland, with pearly lustre, which has obtained the name of satin spar, and that in coloured layers from the interior of Africa.

* For a greater variety of the modifications of crystallized carbonate of lime, sec the British Collection (Room X.), especially Derbyshire and Cumberland. 
Saloon. Case 22, and part of 23. Various specimens Nat. Hrst. of stalactical limestone, some varieties of which bear the name of alabaster in common with compact gypsum; the peculiar variety called peastone, from the hot springs of Carlsbad in Bohemia, and the white variety found in the bed of a small river near Tivoli, and known by the name of confetti di Tivoli.-Calcareous tuf; to which are added some casts of medals, made at the baths of San-Felippe in Tuscany, where moulds of coins, gems, \&c. are placed in convenient situations to receive the calcareous deposition.Shell limestone, the most esteemed variety of which is that from Carinthia, called lumachella or fire marble (see Room I. table-case 5.); and some varieties of anthraconite, called also madrepore stone, from a distant resemblance this substance bears to some petrifactions of the order of corals; fetid limestone, \&c.

Cases 23 and 24. These cases are occupied by suites of brown spar and of arragonite. Among the specimens of the former are many of the scarce fibrous varieties, which were formerly referred to common fibrous limestone; among the latter are Werner's columnar and acicular arragonite, as also fine specimens of the remarkable coralloid variety from Eisenertz in Styria, formerly called flos ferri.

CASE 25 contains the fluates of lime. Among the numerous varieties of fluor spar may be particularized the rose-coloured primitive crystals 
from Chamouni; the phosphorescent massive fuor spar, called chlorophane, from Siberia: the SALOON. NAT. HIST. varieties called fortification fluor; earthy and compact fluor, \&c.

CASE 26 contains the sulphates of lime, which are divided into selenite or sparry gypsum, of which several regularly crystallized, acicular and lenticular varieties are deposited; fibrous gypsum with silky lustre; foliated and compact gypsum, to which latter belongs the stalagmitical variety from Guadaloupe; and the earthy or frothy gypsum, to which may be referred Haüy's niviform variety of sulphate of lime.The remainder of this case is occupied by the anhydrous sulphate of lime, or the cube spar and muriacite of Werner, the compact variety of which is, in some parts of Italy, known by the name of bardiglione.

Case 26*. In this case are deposited the remaining salts of lime. Among the phosphates of lime may be seen several very scarce and interesting crystallizations of Werner's apatite (such as the large crystals from St. Petersburg); the variety called asparagus stone; the Norwegian apatite, called moroxite; also the phosphorite, or earthy and compact phosphates of lime, and the pulverulent variety of the same, known by the name of earth of Marmorosh, and which was formerly considered as a fluate of lime.-Arseniate of lime, called also pharmacolite, from Wittichen in the Black Forest.-Siliciferous borate 
SALOON. of lime: the sparry (Esmark's datholite) and the Nat. Hist. globular fibrous variety of the same (the botryolite of Hausmann), two scarce Norwegian minerals.

CASE 26** contains the barytic salts, viz. the sulphates and carbonates of barytes. Among the subspecies and varieties of the former, called also heavyspar and baroselenite, are, the straightlamellar, variously crystallized, the curved-la. mellar, the columnar and prismatic; also the radiated variety known by the name of Bologna spar, from Monte Paterno near Bologna, and from Bavaria; the compact, called ponderous marble, including the fetid barytes or hepatite, \&c.

Among the specimens of carbonate of barytes, or witherite, may be particularized the beautiful groups of double six-sided pyramids, and those of six-sided prismatic crystals.

CASE 27. Strontian salts; carbonate of Strontian, also called strontianite, in prismatic and acicular crystals, which latter have sometimes been mistaken for arragonite.-Among the sulphates of strontian (celestine of Werner) the more remarkable specimens are, the splendid groups of limpid prismatic crystals from La Catolica in Sicily; the acicular variety in the hollows of compact sulphate of strontian, from Montmartre; the same in fissures of flint; the radiated and fibrous celestine, \&c.

The remainder of this case is occupied by 
some other saline stony substances, viz. carbonate of magnesia, called also pure magnesia, and magSALOON. nesite. Borate of magnesia, or boracite, in separate crystals, and the same imbedded in gypsum; -hydrargillite or wavellite, which may be considered as a phosphate of alumina; azurite and blue spar (Werner's lazulit and blauspath), which appear to be phosphates of alumina, magnesia, and silica ; aluminite, a subsulphate of alumina, from Sussex, and from Halle in the territory of Magdeburg, which was formerly mistaken by some for pure alumina, by others for hydrate of alumina with mechanically admixed sulphate of lime: it must not be confounded with alum-stone (alunite of French mineralogists), which, according to Cordier, is a hydrate of alumina with anhydrous sulphates of alumina and potassa. Fluate of soda and alumina, or cryolite (found only in West Greenland), pure and intermixed with brown iron-stone, galena, \&c.;-mellite or honeystone, which is said to be geognostically related to amber, but is a mellate of alumina.-Glaube. rite (a compound of anhydrous sulphate of lime, and anhydrous sulphate of soda), imbedded in white and blue rock salt, \&c.;-polyhalite of Stromeyer, a chemical combination of several salts, formerly considered as anhydrous sulphate of lime.

CASE 28 contains various saline minerals, among the more remarkable of which are the African trona (carbonate of soda), the fibrous 
SALOON. sulphate of magnesia and soda, from Calatayud NaT. HIst. in Arragon, and the blue salt with glauberite, from Aranjuez in Spain.

In the glazed table-cases and drawers on the right hand side of the principal entry from the first room into the Saloon, are deposited the Metallic ores.

CAse 29. The ores of platina, gold, and mercury.-Platina in grains from Peru and Brasil, the latter mixed with grains of greyish-yellow gold.-Palladium.-Iridium.-Native gold, subdivided into pure and alloyed gold; the former chiefly massive and as grains (from Guinea, Bengal, Sumatra), and in brown iron-stone, in quartz, with needle ore (acicular sulphuret of bismuth, \&c.) from Siberia ; the alloyed gold (principally from Transylvania) crystallized in minute cubes and octahedrons variously aggregated, in reticular plates, \&c.-The ores of mercury in this case are :- the sulphurets, consisting of dark-red cinnabar (by far the more common variety), massive, crystallized, and in combination with various mineral substances; the bright-red cinnabar (native vermilion, much esteemed by painters); the hepatic mercurial ore from Idria, compact and slaty; the former also with petrifactions (coral ore); muriate of mercury, or corneous mercury, with native quicksilver, \&c.

Case 30. This case contains (besides some additional specimens of gold and mercurial ores, among the latter of which is the scarce native amalgam, 
amalgam, crystallized and globular) the ores of silver; between which and the ores of gold are Nar. Hist. placed, the alioy called electrum, from Smeof in Siberia, and the auriferous silver from Kongsberg in Norway, both being a mixture of gold and silver in different proportions. Other alloys of silver are the scarce antimonial silver from Wolfach and Andreasberg, and the arsenical silver from Guadalcanal in Andalusia.-Among the numerous varieties of native silver, may be particularized the various imitative forms in which it occurs, such as tooth-shaped, wireshaped, dendritical, moss-like, reticular, \&c., many of which are aggregations of minute crystals.-Common sulphuret of silver, or vitreous silver; massive, crystallized, and in other external forms, among which are the laminar and capillary.-Brittle vitreous silver, of which some specimens are also deposited in the following table-case. -White silver ore.

CASE 31. The ores of silver contained in this case are the dark and light coloured varieties of red or ruby silver ore, massive, crystallized, and in combination with various substances; the black silver ore, or sooty silver, which has not been analysed; - the muriate of silver, called also corneous silver and horn-ore, of various colours, amorphous, botryoidal, in laminæ, and crystallized in minute cubes and octahedrons; - the very scarce carbonate of silver, also called grey silver ore, from Alt-Wolfach in Suabia, \&c.-In this case begin 
SALOON. the numerous copper ores: among the specimens $\mathrm{N}_{\mathrm{AT} . \mathrm{H}} \mathrm{IsT}$. of native copper (which, like the native silver, presents a great variety of forms besides the crystallized, such as dendritic, filiform, \&c.) may be specified the mass from Hudson's Bay, found by Mr. Hearne, and described by him in his journal.

CASE 32. Ores of copper continued: common sulphuret of copper, or vitreous copper, variously crystallized, foliated, compact, \&c. To this are also commonly referred the oblong, scaly, secondary fossils, known by the name of Frankenberg corn ears, which occur in the bituminous marlslate of Frankenberg in Hessia, and are principally composed of vitreous and grey copper.The variegated copper ore, easily known by the reddish colour of its fractural planes, massive and foliated.-The grey copper ore (fahl ore), crystallized, massive, and disseminated in various substances.

CASE 33. Ores of copper continued : yellow copper or copper pyrites, the most common of all the ores of this metal: among these, is also the pale yellow, fine-grained variety, called hematitiform and blistered copper pyrites.-Seleniuret of copper and silver, called eukairite, in foliated carbonate of lime from Skrickerum, in Smolandia, Sweden.-Red or ruby copper ore, compact, foliated, and fibrous; one of the more remarkable is the bright-red capillary variety from Rheinbreitenbach, in Nassau. To these are added a few specimens of what is called tile-red copper, 
or tile ore, a mixture of red copper ore and brown iron ochre.

SALOON.

Nat. Hist,

CASE 34. Ores of copper continued: black copper, massive, and as superficial covering of other copper ores.-Carbonates of copper : splendid groups of crystallized blue, or azure copper, from Chessy and the Bannat, combined with various substances; and earthy varieties of the same, some of which (called mountain-blue) have been used as pigments.-Crystals passing from the state of blue copper into that of green carbonate (cuivre carbonaté bleu épigène of Haüy).-Green carbonates of copper; among which are the beautiful varieties of fibrous malachite of velvety appearance, in acicular crystals, with carbonate of lead, \&c.

CAse 35. Ores of copper continued : among the specimens of compact malachite, the most beautiful and characteristic are those from the Gumashevsk and Turja mines in the Ural mountains.-Anhydrous carbonate of copper.-Werner's frothy copper ore from Hungary. - In this case is also placed the copper-green of Werner, by some called chrysocolla, a substance often confounded with common green carbonates of copper, but which contains much silica.-To the silicates of copper may likewise be referred the dioptase, a very scarce substance from Siberia, also called emerald copper, on account of its pure green colour; and the very scarce sky-blue velvet copper ore.-Phosphate of copper from 
SALOON. Nassau and Hungary.-Muriate of copper, crysNaT.HIst, tallized and laminar: to which also belongs what is called green sand of Peru, or alacamite, from being found in the desert of Atacama, between Chili and Peru, as sand of a small river. The rest of this case is occupied by the principal varieties of the different arseniates of copper, namely, the foliated arseniate, or copper mica, the lenticular arseniate, or lentil ore, and the olive ore of Werner, which are formed into five distinct species by some mineralogists. (A greater variety of arseniates of copper will be found in the collection of British Minerals: Cornwall.)

CASE 36, AND PART of 37, contain, besides the arsenical iron (called also arsenical pyrites and mispikel), the sulphurets of iron, viz. the common pyrites, smooth and striated; the radiated pyrites, a substance very subject to decomposition, and to which belong most of the varieties of what is commonly called lenticular and coxcomb pyrites, as also the globular pyrites of a radiated texture.

Case 37. Sulphurets of iron continued :The hepatic or liver pyrites of Werner, very dis. tinct from what French mineralogists call fer sulfuré hépatique, which latter is decomposed common and radiated iron pyrites, and sometimes brown iron-stone.-Magnetic pyrites, which is nearly allied to the preceding species : massive and crystallized in six-sided prisms.-The remainder of this table-case is occupied by part of 
the oxides of iron: magnetic iron-stone massive, SALOON. of various grain, compact, crystalllzed, in ser- NАт. Н pentine, chlorite slate, \&c.; ore which yields the rootz, a very hard kind of iron from the East Indies; magnetic iron-sand; the variety of oxidulous iron with admixed manganese and zinc, called franklinite, from New York, \&c.

Case 38, and part of 39. Oxides of iron continued: specimens of specular iron, or iron glance, among which, those from the island of Elba are remarkable on account of their beautiful iridescence and play of colours; variety in large laminar crystals, appearing like polished steel, from Stromboli, \&c.; the micaceous iron ore of Werner, belonging partly to this species, partly to the scaly red and brown iron-stone (in the next table-case); among the most remarkable specimens of which is that in delicate, trans. parent tables of a blood red colour, from NassauSiegen, called goethite: that in scales, coating the cells of lava: a shining brownish-black variety used as hair powder by the Bootchuana natives beyond the Great River in South Africa, \&c.

CASES 39 AND 40 contain the different varieties of compact red iron-stone and red hematite, and of hydrous oxides of iron, the latter, comprehending Werner's ochrey and compact brown iron-stone and brown hematite, together with several varieties of argillaceous or clay iron-stone, such as common, columnar, pisiform, reniform, clay iron-stone, meadow-ore, \&c.-Salts of iron; 
SALOON. viz. carbonate of iron, or spathose iron ore, the

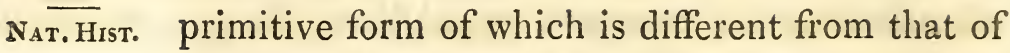
carbonate of lime: crystallized, massive, and botryoidal (sphcerosiderite of Hausmann) in basalt.-Arseniate of iron, or pharmacosiderite, which occurs only crystallized, chiefly in cubes, whence Werner's name of cube ore. [See British Collection: Cornwall.]-Cupriferous arseniate.-Scorodite.-Chromate of iron, among the specimens of which is one from Baltimore, in which this substance is intermixed with talc stained purple by chromic acid. - The pyrosmalite, considered by some as a muriate of iron.Phosphate of iron, crystallized (with native gold, from Transylvania), massive and pulverulent: among the specimens of the latter are, the massive variety from New Jersey, and several earthy varieties, in clay, wood, peat, \&c. To these is added the ilvait (the yenite or jenite of some mineralogists), which is enumerated by Haüy among the ores of iron, under the appellation of fer silicéo-calcaire.

CASE 41. In this and the two following cases are contained the ores of lead, the most common and useful of which is the sulphuret of lead, or galena; the specimens here deposited include various modifications of crystals, detached, and grouped together, in combination with blende, pyrites, and many other substances ; galena of various grain, massive and disseminated; galena of corroded appearance, decomposed and re- 
generated; the compact and specular variety, called slickenside by the Derbyshire miners. With these is also placed the antimonial sulphuret of lead, or triple sulphuret of lead, antimony, and copper, called endellion by Count Bournon. [See British Collection : Cornwall.]

Case 42. Ores of lead continued:-the more prominent specimens in this case are those of carbonate of lead, or white lead, among which may be particularized the laminar varieties, the beautiful modifications from Siberia, and the crystallized acicular white lead from the Hartz, accompanied with green and blue carbonates of copper; the fine light-blue variety coloured by copper, \&c.; the black lead ore of Werner, which appears to be merely a variety of the white lead ore.-With these are placed three substances from Leadhills, hitherto considered as carbonates, but which, according to analyses lately published, are, sulphato-carbonate, sulphato-tricarbonate, and cupreous sulphate of lead.Phosphates of lead, which are divided by Werner into brown lead ore, and green lead ore. Among the specimens of the brown phosphate, the most remarkable are the large six-sided prisms from Huelgoet in Britany, \&c.

CAse 43. Ores of lead continued:-green phosphate, massive, botryoidal, spicular, \&c.; variously crystallized; of various shades of green, passing into greenish-white, into yellow
SALOON.

NAt. Hist. 
SALOON. and orange; with ferruginous quartz, straightмат. Hrsт. foliated, heavy-spar, \&c. from Freiberg in the Brisgau, \&c.-Arseniate of lead.-Molybdate of lead, or yellow lead ore, massive, lamelliform, and crystallized; on compact lime-stone, \&c. chiefly from Bleyberg in Carinthia.-The specimens of chromate of lead, or red lead ore, deposited in this case, are particularly beautiful and instructive: the accompanying substances are green lead ore, and sometimes small greenishbrown crystals of a substance (Vauquelinite) which appears to be chromate of copper and lead: the gangue stone, in which the red lead occurs in the gold mines of Beresof, is a kind of micaceous rock mixed with particles of quartz and brown iron-stone.-Murio-carbonate of lead, or horn-lead, the crystallized varieties of which have hitherto been observed in Derbyshire only. [An interesting suite of crystals of this scarce mineral substance will be found in the British Collection: Derbyshire.] - Sulphate of lead, called native lead-vitriol by Werner, crystallized and massive.-Lead earth, indurated and friable, of various colours; its different varieties appear to be related to carbonates, phosphates, and sulphates of lead: to which latter also the reniform lead ore (blei-niere of Werner), from Siberia, appears to belong: some varieties of lead earth are oxides. Near to these is also placed the native minium, from Hessia, first described by 
Mr. Smithson, and varieties of the same from SALOON. Siberia; all of them probably produced by the Nar. Hist. decay of galena.

CASE 44. Ores of zinc. Among the many varieties of sulphuret of zinc, or blende, may be particularized those relative to colour, viz. the yellow, the brown, and the black blende of Werner; the first of which is generally most pure, while the two others contain a portion of iron ; the fibrous blende of Przbram in Bohemia, in which the cadmium was discovered by Stromeyer; the variety called testaceous blende (schaalen-blende), the most characteristic specimens of which are from Geroldseck in the Brisgau, contains, besides iron, a portion of lead. - The other ores of zinc in this case are those of a sparry appearance, commonly called calamine, which constitute three different species, viz. the electric or siliceous calamine, in a variety of which the presence of cadmium has been announced by the late Dr. Clarke; the common calamine, or native carbonate of zinc; and the red cxide of zinc: the specimens of the two former species include various crystalline and other forms, among which are the pseudomorphous crystals of carbonate of zinc, derived from modifications of calcareous spar.

CASE 45. Ores of tin, of which we have the sulphuret of tin, or tin pyrites, and the oxides, which are divided into common tin-stone, and wood-tin:-tin pyrites, hitherto only found in

Cornwall, 
SALoon. Cornwall, nearly pure, mixed with copper pyNat. Hist. rites, \&c.; - among the specimens of common tin-stone are, the regular and macled crystals, the pebble-like and granular tin stone (shoad tin, stream tin, grain tin, \&c.), and the greyishwhite crystals, resembling scheel ore, or tunsgate of lime; the tin stone from Finbo, in Sweden, which contains oxide of tantalum.-The ores of tungsten, which frequently accompany those of tin, are-wolfram (schéelin ferrugineux of Haüy), crystallized and massive, from Bohemia, \&c. and the tunsgate of lime, scheel ore (schéelin calcaire of Haüy), among the crystallized specimens of which is the primitive acute octahedron from Allemont in Dauphiné.-In this case are also placed the specimens of molybdena, or sulphuret of molybdenum, which should not be confounded with graphite; the yellow powder on feldspar, from Westmania in Sweden, in oxide of molybdenum.

CaSe 46. Part of this case is occupied by the ores of titanium, viz. the oxides, called titcinite, brown-ore, brunon (sphène, and titane silicéo-calcaire of Haüy), among the varieties of which is that in large flat octahedral crystals from Norway, with epidote, \&c. also the variety called, by Saussure, rayonnante en gouttière, from St. Gothard, on feldspar, with chlorite, \&c.-Titanshorl, also called rutile; massive, crystallized, and fibrous, to which latter belongs the variety with golden tarnish, from Moutier, near the Montblanc; 
Montblanc; the acicular crystals of rutile in rock crystal, \&c.; the ferriferous oxides (sideroSALOON. NAT. Hist. titanium of Klaproth), some varieties of which may be considered as titaniferous oxides of iron, and to which may be referred the black sand called menachanite, and the iserine, in loose grains and imbedded;-specimens of anatase, or octahedrite, from Dauphiné :- the same, together with a scarce substance called crichtonite (craytonite of Bournon), which has been considered by some as a variety of helvine, and as a silicate of zirconia by others, but appears to be a silicate of titanium. The remainder of this table-case contains the ores of antimony ; native antimony, from Allemont, and from Sala in Sweden, some varieties of which are arseniferous; - sulphuret of antimony, or grey antimony (the most common ore of this metal), occurs compact, foliated, radiated, and plumose : the more remarkable among these are the specimens of crystallized radiated antimony in fine groups, especially from Transylvania ; radiated grey antimony with barytes, realgar, \&c., the plumose grey antimony, some varieties of which, appearing like delicate wool or down, display a fine iridescent blue, yellow and red tarnish; red antimony, mostly in fine capillary crystals, from Bräunsdorf in Saxony, and a variety of the same, called tinder ore, from the Hartz; -white antimony, an oxide, formerly considered as a muriate, of this metal, crystallized, on galena, \&c. 
SALOON. - specimens of antimonial ochre on native and NAT. Hist. grey antimony, \&c.

Case 47, and fart of 48, contain the ores of cobalt and arsenic. The crystals of glantz-cobalt, which has been frequently confounded with white cobalt, are mostly from Sweden ; - a suite of specimens of white cobalt, exhibiting the principal modifications of crystallized and irregular forms ; grey cobalt, principally from Wittichen in Würtemberg;-some specimens of oxides of this metal, viz. the black and the brown or yellow cobalt ochre, the latter of which contains iron; various specimens of the red cobalt ore, or arsenite, comprising the earthy (cobalt crust) and the radiated (cobalt bloom) varieties from Saalfeld, Allemont, \&c. Between these and the remaining metallic substances in the adjoining table-case are deposited the ores of arsenic ; native arsenic (formerly called testaceous cobalt) in reniform and botryoidal shapes, from Andreasberg, \&c.; - -splendid and instructive specimens of the sulphurets of this metal, viz. the yellow orpiment, massive, and in separable, striated, transparent laminæ; and the red orpiment or realgar, perfectly crystallized and massive, and also (in the large specimen in the centre) as colouring matter between the laminæ of crystallized straight-foliated heavyspar; - -specimens of the native oxide of arsenic, showing the octahedral form of its primitive crystals.

Case 48. The contents of this case are :- 
The ores of nickel, among which may be partiSALOON. cularized the native nickel from Saxony, which Nat. Hist. was formerly classed with the ores of iron, under the denomination of capillary pyrites ; the arsenical nickel, called copper nickel; nickel ochre, which is no oxide, but an arseniate of nickel.Ores of bismuth : native bismuth, massive, disseminated and dendritic in jasper; to which is added a specimen exhibiting the artificial crystallization of the same, produced by sudden cooling of the melted metal; - sulphuret of bismuth, the bismuth glance of Werner, with which is placed the Siberian needle ore of the same mineralogist, being a triple sulphuret of bismuth, lead, and copper.-Ores of uran : the protoxide of uranium, called pitch ore, massive, pure, and with adhering ochre of the same metal;-the substance called uranite, or uran mica, in groups of emerald-green and yellow colours. The ores of tellurium or sylvane, which are divided into native tellurium, white and yellow (alloyed with gold and iron ); the graphic ore, so called on account of the disposition of its minute laminar crystals into groups that bear a distant resemblance to written characters; and the black tellurium ore, or Nagyag ore (commonly containing gold and some lead).

CaSE 49. The greater part of this case is occupied by the ores of manganese, viz._oxides: radiated grey manganese, some varieties of which re- 
SALOON. semble the radiated antimony in the disposition of NaT. Hrst. their acicular crystals ; foliated grey manganese ; compact manganese of various forms, botryoidal, tubercular, reniform, \&c. ; earthy grey manganese, a remarkable variety of which is the black road of Derbyshire and Devonshire, which has the property of inflaming spontaneously when mixed with linseed oil.-Silicates of manganese; the red compact varietiesfrom Siberia (Werner's manganspath), and from Kapnik (the red manganese of the same mineralogist).-Carbonate of manganese, phosphate, \&c.-The helvine, referred by some mineralogists to Bournon's crichtonite, from which, however, it appears essentially to differ.

In this case are also placed the ores of columbium or tantalum, of yttria, and of cerium, \&c.Columbite :- the specimen from North America in which Mr. Hatchett discovered the metal (see Phil. Trans. 1802); yttriferous columbite or yttrotantalite, from Bavaria, \&c. -Silicate of yttrium: gadolinite, of which a unique crystal is here deposited: pyrorthite and orthite, two scarce Swedish minerais, related to gadolinite.-Cerite or cerine (silicate of cerium) from Bastnaes in Sweden.-Yttrocerite, a fluate of lime, yttria and cerium; and a related mineral composed of fluate of yttria and oxide of cerium, with only a small portion of lime, but in which is often found a fluate of the new earth to which Berzelius has given the name of thoria.-Specimens of the oxide 
oxide of chromium, in quartz, discovered by $\mathbf{M}$. Leschevin in the department of the Saone and NaT. Hist. Loire.

In the opposite compartment of this table-case are deposited, as appendix to the ores of iron, the substances called aërolithes, because they have fallen from the atmosphere, and meteoric stones, because they are by some supposed to be deposited from meteors. The specimens belonging to the former are-native iron from Gross-kamsdorf in Saxony; - two small polished pieces of the mass found in Southern Africa, which weighed about 250 pounds, and is now in the cabinet of Haarlem; -fragment of the iron from Senegal:- specimens of the native iron from Otumpa, in the Gran Chaco Gualamba, in South America, described by Don Rubin de Celis, who estimated the weight of the mass to be about 300 quintals, or 15 tons ;-a large piece detached from the celebrated mass of Siberian native iron, which was discovered by Pallas on the summit of a hill between Abakansk and Belskoi Ostrog on the banks of the Jenisey, where it was considered by the Tartars as a sacred relic: the mass originally weighed about 1,680 pounds; - a piece of the large mass from Ellenbogen, in Bohemia, and another of that found on Collina di Brianza, in Milan;-a small piece of the large mass in the Capitania di Bahia, Brasil; -a specimen detached from the large mass of 
SALOON. iron preserved at Aix-la-chapelle;-an EsquiNat. Hrst. maux knife and harpoon (from Davis's Straits, Lnt. $76^{\circ} \mathrm{N}$. Long. $66^{\circ} \mathrm{W}$.), the iron of which is meteoric; - native iron from Lenarto, Hungary; -from the province of Durango, Mexico. of meteoric stones (classed with native iron, because they all contain this metal alloyed with nickel), the following are placed in chronological order: -a large fragment of the stone which fell at Ensisheim, in Alsace, Nov. 7th, 1492, in the presence of the Emperor Maximilian, thenking of the Romans, when on the point of engaging with the French army : this mass, which weighed 270 pounds, was preserved in the cathedral of Ensisheim till the beginning of the French revolution, when it was conveyed to the public library of Colmar; - one of the many stones which fell, July $3 \mathrm{~d}$, 1753, at Haun, in the circle of Bechin, Bohemia, and which contain a great proportion of attractable iron; specimens of those that were seen to fall at Roquefort and at Juliac, in the Landes of Gascony, July 24th, 1790 ;-one of a dozen of stones of various weights and dimensions that fell at Sienna, in Tuscany, Jan. 16th, 1794;-fragment of the meteoric stone, weighing 56 pounds, which fell near Wold Cottage, in Yorkshire, Dec. $13 \mathrm{in}, 1795$; - fragment of a stone of 20 pounds, which fell in the commune of Sales, near Villefranche, in the department of the Rhône, March 12 th, 1798 ; - specimens of stones fallen near the city 
city of Benares, in the East Indies, Dec. 19th, 1798 ; - an entire and a broken specimen of the SALOON. meteoric stones of which a shower descended at Aigle, in the department of the Orne, April 26th, 1803 ; - fragment of that of Smolensk, June 27th, 1807 ; - fragment of one of those that were seen to fall at Weston, in Connecticut, Dec. 14th, 1807; -two meteoric stones with shining black surfaces fallen May 22d, 1808, at Stannern, in Moravia :- two fragments of the Tipperary aërolite, which fell in August, 1810: it contains quartz globules of a green colour, owing to oxide of nickel; a fragment of that of Berlanguillas, in Catalonia, July 8th, 1811 ; - - fragment of one, weighing 66 pounds, which fell August 5th, 1812, near Chantonnay, in the Vendée;-fragment of the meteoric stone which fell at Adare, in the county of Limerick, Ireland, in 1813;fragment of one of those which fell Sept. 5th, 1814, at Agen, in the Pyrenees, and one of that which descended at Juvénas (Ardêche), on June 15 th, 1821 . 
SALOOR.

NAT. Hist.

ORDER OF THE TABLE-CASES IN THE SALOON.
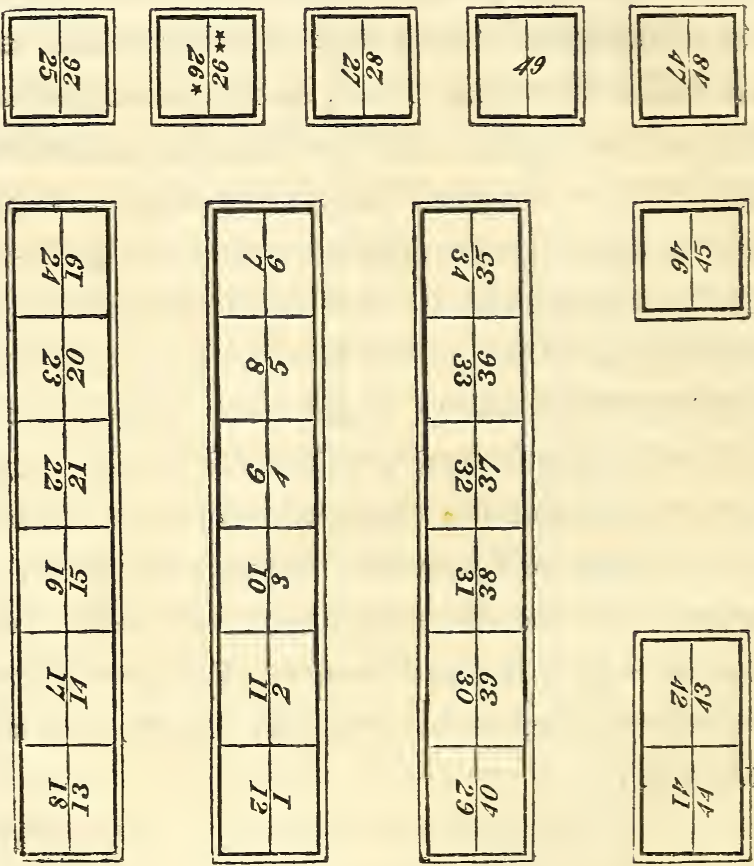


\title{
ALPHABETICAL LIST OF THE MINERALS SALOON. IN THE SALOON,

\author{
WITH REFERENCES TO THE TABLE-CASES AND
}

THE DIAGRAM.

Actinote, 15

Adularia, 12

Aërolite, 49

Agalmatolite, 18

Agaric mineral, 22

Agate-jasper, 9

Alalite, 14

Albite, 12

Allochroite, 13

Alum, 28

Alumina, subsulphate of, 27

Aluminite, 27

Amalgam, native, 30

Amber, 1

Amethyst, 4

Amianth, 16

Amphigene, 12

Antimony, native and ores of, 46

A ualcime, 10

Anatase, 46

Andalusite, 2, 11

Anliydrite, 26

Anthophyllite, 16

Anthracite, 1

Anthraconite, 22

Apatite, 26*

Aphrite, 21

Aplome, 13

Apophyllite, 10

Arragonite, 23, 24

Arsenic, ores of, 46,47

Asbest, 16

Asparagus-stone, 26*

Asphaltum, 1

Atacamite, 35

Avanturino-quartz, 6

Augite, 14

Automolite, 3

Axestone, 16

Axinite, 1.5

Azurite, 27

Barosolenite, 26***

Barytes, salts of, $26^{* *}$
Bergmannite, 11

Beryl, 3, 4

Bismuth, ores of, 48

Bitter spar, 22

Bitumen, 1

Black lead, 1

Blende, 44

Blood stone, 7

Blue-spar, 27

Bog-iron ore, 40

Bole, 18

Bolognese spar, 26**

Bolacite, 27

Bolax, native, 28

Botryolite, 26*

Bommonite, 2

Brown coal, 1

Brown ore, 46

Brown spar, 23, 24

Brumon, 46

Cacluolong, 7, 8

Calamine, 44

Calcareous spar, 19,20 Cymophane, 3

Calcedony, 6

Carnelian, 7

Cat's eye, 5

Celestine, 27

Cerite, 49

Ceylonite, 3

Chabasite, 10

Chalk, 22

Chiastolite, 12

Chlorite, 17

Chlorophane, 25

Chromium, oxide of, 49

Clirysoberyl, 3

Chrysocolla, 35

Chrysolite, 14

Chrysoprase, 7

Cinnabar, 29

Cinnamon stone, 13

Clay-iron stone, 39

Cobalt, ores of, 47

Datholite, $26 \%$

Diallagou, 16

Diamond, 2

Diaspore, 2

Dichroite, 9

Diouside, 14

Dioptase, 35

Dipyre, 10

Distlene, 3

Dolomite, 21

Dysodile, 1

Fiacolite, 11

Electrum, 30

Emerald, 3

Emerald-copper, 35

Emery, 2, 37

Endellion, 41

Fpidote, 14

Cobalt, sulphate of, 28 Epsom salt, 28

Euclase, 3 
SALOON. Eucarite, 35

Euchysiderite, 14

Nat. Hist. Eudialyte, 11

Fahlunite, 18

Feldspar, 11, 12

Fibrolite, 2

Fish-eye stone, 10

Flint, 7

Flinty-slate, 8

Fluor spar, 25

Franklinite, 37

Fuller's earth, 18

Gadolinite, 49

Galena, 41

Garnet, 13

Gehlenite, 13

Glance-cobalt, 47

Glauberite, 27

Glauber salt, 28

Gœthite, 38

Gold, 29

Graphite, 1

Green earth, 18

Grenatite, 13

Grossular, 13

Gurhovian, 21

Gypsum, 26

Harmotome, 11

Haiiyne, 11

Heavy spar, 26 *

Heliotrope, 7

Helvine, 49

Hematite, red, 39

- brown, 39

Hepatic ore, 29

Hepatite, 26

Honey stone, 27

Hornblende, 14, 15

Horn lead, 43

Horn silver, 31

Horn stone, 8

Hyacinth, 2, 13

Hyalite, 6

Hydrargillite, 27

Hypersthène, 16

Icespar, 12

Ichthyophth

Idocrase, 13

Ilvait, 40

Indianite, 12

Iolite, 9

Iridium, 29

Iron, arsenical, 36

- hydrates of, 39

- nieteoric, 49

- native, 49
Iron, oxides of, 37, 38 Magnesite, 27

- salts of, 40 Malachite, 34,35

- sulphurets of, 36 Manganese, ores of, 49

Iron-flint, 6

Iron-glance, 38

Iron-mica, 38

Iron-pyrites, 36

Iron-sand, 37

Iron-spar, 40

Marekanite, 9

Marl, 22

Marmolite, 18

Meerschaum, 18

Meionite, 11

Melanite, 13

Iron-stone, brown, 39 II elilite, 12

- magnetic,

$$
37
$$

Iron-vitriol, 28

Iserine, 46

Jade, 11

Jasper, 9

Jasp-opal, 8

Jeffersonite, 14

Jet, 1

Karpholite, 11

Keffekilite, 18

Kohlenblende, 1

Koupholite, 11

Kyanite, 3

Mellite, 27

Menacanite, 46

Menilite, 8

Mercury, native, and ores of, 29,30

Mesotype, 10

Meteorite, 42

Mica, 17

Minium, native, 43

Mispickel, 36

Molybdenum, ores of, 45

Moroxite, 27, 26*

Muriacite, $26^{\circ}$

Mussite, 14

Nagyag-ore, 48

Naphtha, 1

Natrolite, 10

Labrador spar, $12 \quad$ Needle-ore, 47

Labrador hornblende, Needle-stone, 10 16

Laumonite, 10

Lazulite, 11

Lead, native, 43

- , oxides of, 43 Obsidian, 9

- , salts of, 42,43

- sulpliurets of, 41

Lead-earth, 43

Lead-vitriol, 43

Lentil-ore, 35

Lepidolite, 17

Leucite, 12

Lievrit, 40

Nickel, alloys and ox. ides of, 47,48

Nitre, native, 28 $26 \%$

$\longrightarrow$, carbonate of, 19-23

Octahedrite, 46

Olive ore, 35

Olivine, 14

Opal, 8

Orpiment, 47

Orthite, 49

Palladium, 29

- , fluate of, 25

- plosphate of, 26* , sulpliate of, 26

Limestone, 21, 22

Lithomarge, 18

Liver-pyrites, 37

Lydian-stone, 8

Madrepore stone, 28 $\begin{aligned} & \text { Pitch ore, } 47,48 \\ & \text { Pitchstone, 9 }\end{aligned}$

Magnesia, hydrate of, 17 Platina, 29

Pearl sinter, 6

Pearl stone, 9

Pelioma, 9

Petalite, 12

Petroleum, 1

Pharmacolite, 26*

Phospliorite, 26*

Pimelite, 7

Pinite, 17

Pistacite, 14

-, salts of, 27, 28 Pleonaste, 2

Maguesia and soda, Polyhalite, 27

sulphate of, 28

Potash, nitrate of, 28 


\begin{tabular}{|c|c|c|c|}
\hline Potstone, 17 & Serpentine, 18 & Titanium, ores of, 46 & SALOON. \\
\hline Prase, 5 & Shorl, 4 & Topaz, 3,4 & \\
\hline Prehnite, 11 & Siderite, $\mathbf{5}$ & Toumaline, 3, 4 & NAT. HIST \\
\hline Pumice, 9 & Siderotitaniun, 46 & & \\
\hline Pycnite, 3 & Silver, native and ores & Triclasite, 18 & \\
\hline $\begin{array}{l}\text { Pyrites, } 36,37 \\
\text { Pyrope, } 13\end{array}$ & of, 30,31 & Trona, 28 & \\
\hline $\begin{array}{l}\text { Pyrope, } 13 \\
\text { Pyropliysalite, } 3\end{array}$ & Silver-black, 31 & Tungsten, 45 & \\
\hline $\begin{array}{l}\text { Pyropliysalite, } 3 \\
\text { Pyrortlite, } 39\end{array}$ & $\begin{array}{l}\text { Silver-glance, } 30 \\
\text { Sinter, } 6\end{array}$ & Turquois, 2 & \\
\hline Pyrosmalite, 40 & $\begin{array}{l}\text { Sinter, } 6 \\
\text { Slate spar, } 21\end{array}$ & Uranium, ores of, 47 , & \\
\hline Pyroxene, 14 & $\begin{array}{l}\text { Smaragdite, } 16 \\
\text { Soda, salts of, } 28\end{array}$ & 48 & \\
\hline Quartz, 5 & Sphene, 46 & Velvet-copper, 35 & \\
\hline Quicksilver, native, 30 & $\begin{array}{l}\text { Spinel, 3 } \\
\text { Spodumen, } 12\end{array}$ & Vesnvian, 13 & \\
\hline Realgar, 47 & Staurolite, 13 & Wad, 49 & \\
\hline Retinasphaltum, 1 & Steatite, 18 & Wavellite, 27 & \\
\hline Rliaticite, 15 & Steinheilite, 5 & Wernerite, 11 & \\
\hline Rock crystal, 4 & Stilbite, 10 & Witherite, 26** & \\
\hline Rock salt, 28 & Stinkstone, 22 & Wolfram, 45 & \\
\hline $\begin{array}{l}\text { Rockwood, } 16 \\
\text { Rubellite, } 3\end{array}$ & $\begin{array}{l}\text { Stones, meteoric, } 49 \\
\text { Strontian, salts of, } 27\end{array}$ & $\begin{array}{l}\text { Woon-opan, } 8 \\
\text { Wood-stone, } 8\end{array}$ & \\
\hline $\begin{array}{l}\text { Rubellite, } 3 \\
\text { Ruby, } 2\end{array}$ & $\begin{array}{l}\text { Strontuan, salts or, } 28 \\
\text { Sulphur, } 1\end{array}$ & Wood-tin, $45^{\circ}$ & \\
\hline $\begin{array}{l}\text { Ruby-copper, } 33 \\
\text { Ruby-silver } 31\end{array}$ & & & \\
\hline $\begin{array}{l}\text { Ruby-silver, } 31 \\
\text { Rutile, 46 }\end{array}$ & Tabular-spar, 21 & Yenite, 40 & \\
\hline Rutile, $4: 6$ & $\begin{array}{l}\text { Talc, } 17 \\
\text { Tantalite, } 49\end{array}$ & Yitrocerite, 49 & \\
\hline $\begin{array}{l}\text { Salite, 14 } \\
\text { Sapphire, } 2\end{array}$ & $\begin{array}{l}\text { Tellurium, ores of, } 47 \text {, } \\
48\end{array}$ & $\begin{array}{l}\text { Zeolite, } 10 \\
\text { Zircon, 2 }\end{array}$ & \\
\hline Scapolite, 11 & Tharandite, 21 & Zinc, salts and sulplue- & \\
\hline $\begin{array}{l}\text { Scheel-ore, } 45 \\
\text { Scolicite, } 10\end{array}$ & Tile-ore, 33 & rets of, 28,44 & \\
\hline $\begin{array}{l}\text { Scolicite, } 10 \\
\text { Scorodite, } 40\end{array}$ & Tin, ores of, 45 & Zinc, vitriol, 28 & \\
\hline $\begin{array}{l}\text { Scorodite, } 40 \\
\text { Selenite, } 26\end{array}$ & Tinder-ore, 46 & Zoisite, 14 & \\
\hline Selenite, & Titan-shorl, 46 & & \\
\hline
\end{tabular}

\section{EIGHTH ROOM.}

The upright Cases on the south side of the Room vill. room contain the general collection of birds NAT.HIST. $_{\text {. }}$ arranged in orders, with the larger specimens which could not be placed in the lower cases, disposed in those above them.

The upper part of Cases 1 and 2 contains the Rapacious birds (the Accipitres of Linn. except 
Roon vilr. his genus Lanius), which feed on living or dead NaT. Hist. animals.

Cases 2 To 6 contain the smaller perching birds (the Passeres and Picæ of Linn.), divided into groups, after Cuvier.-1 1st. The Fissirostral birds, which take their food flying, as the Swallows; 2d. The Dentirostral, which live on insects and worms, as the Flycatcher and Butcher birds; 3d. The Conirostral, living on seeds, as the Finches; the Scansorial, or climbing birds, as the Parrots and Woodpeckers; and lastly, the Tenuirostral, or Honey-sucking birds, as the Humming birds.

CASES 6* aNd 7, contain the gallinaceous birds (Gallinæ of Linn.).

CASES 8, 9 AND 10 contain the wading birds (Grallæ. Linn.) which live near water.

Cases 11 and 12 contain the swimming birds, as the Ducks, Darters, Gulls (Anseres, Linn.).

CASE 13, near the door, contains some curious nests and eggs of birds, as the Edible nest, the Tailor-bird's nest, and the foot of an unknown bird, supposed to belong to the Dodo.

Cases 43 and 44, between the windows, contain some large specimens of corals and seaeggs.

CASE 45, near the door, contains the specimens of shells too large to be placed in the Tables.

The Barnacles, or Cirripedes, are placed in the 
the Tables, No. 3, 4, near one of the windows; Roon vil. No. 3 contains the pedunculed Barnacles, suchas NAT. H.sт. the Eared Barnacles, \&c., and parasitical sessile Barnacles, which live in and on coral. No. 4. The common sea-acorn shells, and the genera Coronula and Tubicinella, which are parasitical on the whale's, and Chelenobia on the turtle's backs.

In the window is placed a large group of the common Barnacles in spirits.

The general collection of SHeLLs is contained in the Tables in the middle of the room, and in one of the windows. They are arranged according to Lamarck, (Histoire Naturelle des Animaux sans Vertebres,) whose names are placed on the left side of the bottom of the Tablets, and the Linnæan, or other synonyma, on the right.

The Bivalve Shells, or the Conchifera of Lamarck, are placed in the Tables No. 5 to 16.

TABLE 5 contains the families of the Tubico. laria, Pholadaria, and part of the Solenacea. Amongst them are the Aspergillum javanum, or watering-pot shell; Clavagella, probably the only recent shell of the kind known; Fistulana clava, Septaria arenaria, or great bifurcated Teredo, Teredo navalis, or ship-worm: Pholas dactylus, or prickly piercer, Gastrochæna cuneiformis ; several solenes, or razor-shells, Panopæa Aldrovandi (Mya Glycimeris, Linn.), or great gaper, \&c.

TAbLe 6 contains the families Myaria, Mactracea, 
ROOM VIII. Nat. Hist.

tracea, Corbularia, and Lithophaga. Amongst them are Mya truncata, Anatina laterna, Lutra. ria solenoides (Mya oblonga. Gmel.), Mactra Spengleri, M. gigantea, and M. stultorum, Crassatella, Erycina cardioides, Ungulina transversa, Solenomya Mediterranea (very scarce), Amphidesma, Corbula nucleus, Pandora, Saxicava, Petricola, and Venerupis. The three last genera perforate rocks, and make their habitations therein.

Table 7. The families, Nymphacea solenaria, and $N$. tellinaria-Conche fluviatiles and part of the Concha marina. Amongst the Nymphacea, are the Sanguinolaria rosea (Solen sanguinolentus. Gmel.), and S. rugosa (Venus deflorata. Gmel.), Psammobia ferroensis, various Tellinæ, Corbis fimbriata, Lucina pensylvanica,several species of the genus Donax, and the genera Capsa and Crassina. Under the families of the Conchæ, are Cyclas, Cyrena, and the very rare shell Galatæa radiata (Venus subviridis. Gmel.), Cyprinæ and part of the genus Cytheræa.

TABLE 8. Cythercece, and part of the Veneres, containing several species of each genus.

Table 9. The remainder of the genus Venus, and the genus Venericardia, of which very few species are known, except in the fossil state. The family of the Cardiacea are also included in this compartment, namely, the genera Cardium, Cardita, Cypricardia (the two last were classed 
classed by Linnæus with the Chama), Hiatella Room virr. (Mya of Linnæus), and Isocardia. The last ge- Nat. Hıт. nus includes the rare and elegant shell Isocardia Moltkiana-the Chama Moltkiana of Gmelin.

Table 10. The families Arcacea, Trigoniana, and part of the Naiada. Amongst them are the Cucullæa auriculifera (Arca cuculis. Gmel.), several species of the genera Arca and Pectunculus, and the genus Nucula (the two latter were confounded with the Arcæ, by Linnæus); the genus Trigonia, and part of the genus Unio (Mya of Linn.), some species of which furnish pearls of considerable size and beauty. Several new species of Unio from North America.

TABLE 11. Unio continued; and the genera Hyria, Anodonta (Mytilus. Linn.), and a single valve of the Iridina ovata (?) a very rare genus, of which Lamarck gives but one species. Also the families Chamacea, Tridacnea, and part of the Mytilacea. Of the Chamacea, is a specimen of the Diceras arietina, the only known species of this genus, and hitherto not found as a recent shell; also various species of Chama; and three species of the fresh-water genus Etheria, all of which are rare.

TABLE 12. The second Order of this class, Conchifera unimusculosa, begins with the family Tridacnea, comprehending the genera Tridacna and Hippopus--Some shells of the former genus, of the species Tridacna gigas, are the largest that are known; they are said to have 
ROom VIII. been found of 500 pounds weight. Part of the Nat. Hist. genus Modiola (Mytilus. Linn.), of the family of the Mytilacea, are contained in this compartment; and the genera Mytilus (the muscle) and Pinna.

TABLE 13. The family Malleacea, and part of the Pectenida; including under the former, the genera Crenatula (rather rare shells), Perna, Malleus (the two last classed as Oysters by Linnæus), Avicula (Mytilus. Lin.), and Meleagrina. The Meleagrina margaritifera (Mytilus margaritiferus. Lin.) affords valuable pearls, and the inside is formed of the beautiful substance known by the name of Mother of Pearl. Under the Pectenida, are included the genera, Pedum, containing only one species, P. Spondyloideum (Ostrea spondyloidea. Gmel.), Lima, Plagiostoma (fossil), and Pecten, or Scallop shell. The Lima and Pecten were considered as Ostreæ by Linnæus.

Table 14. Pecten continued; and the genera Plicatula and Spondylus, or hinged Oyster.

Table 1.5. Ostracea, including the genera Gryphæa (only one recent species of this genus, G. angulata, is known); Ostrea, Vulsella, and Placuna.

Table 16. Anomia, the last genus of the Ostracea. Also the families Rudista, and Brachiopoda. In the first, are the fossil genera Radiolites and Calceola, and the recent genus Crania ; in the latter the genera Orbicula, Terebratula (Anomia of Linnæus), and Lingula. Of 
this genus, which is the last of the Conchifera, Roon vir. only one species, L. anatina (Pateila unguis. Nat. Hist. Lin.), is known.

The Univalve Shells, or the Mollusca of Lamarck, commence in this Table. The MoLlusca Pterofoda contain one family, viz. Hyalceana, which includes the genus Hyalæa; and the Mollusca Gasteropoda containing the families Phyllidiana, and Semi-Phyllidiana, are likewise in this compartment. In the first are the genera Chitonellus, Chiton, or Coat of Mail shell, and the Patella, or limpet. In the second the genus Umbrella.

TABLE 17. Calyptracea, Bulloeana, Laplysiana, and Limacina, the four remaining families of the Gasteropoda. The genera of the Calyptracea are, Parmophorus, or Thracian shield shell, Emarginula, Fissurella, Pileopsis, Calyptræa, Crepidula, and Ancylus. The Bullæana contain the Bullæa aperta (Bulla aperta. Lin.), and several species of the genus Bulla. Laplysia and Dolabella are the genera of the next family. The shell of the former is a small cartilaginous scutcheon, which adheres to the posterior part of the back of the animal; that of the latter is wholly internal. The genera of the family Limacina are, Parmacella, an internal shell, very rarely met with; Limax (the Slug), whose shell, a small testaceous lamina, is contained in a fleshy or coriaceous scutcheon, at- 
ROOM vir. tached to the fore part of the back of the aniNaT. Hrst. mal;-Testacella, and Vitrina. The shells of the two last genera are external.

The Mollusca Trachelipoda, or Spiral Shells, commence with the family Colimacea and contain the genus Helix, a part of the numerous species of which are in this compartment.

TABLE 18. Helix continued, together with the genera Caracolla, Anostoma, Helicina, Pupa, Clausilia, and Bulimus.

TABLE 19. The four remaining genera of the Colimacea, viz. Achatina, Succinea, Auricula, and Cyclostoma.

TABle 20. The families Melaniana, Peristomata, and part of the Neritacea. 'The genera of the first are Melania, Melanopsis and Pirena: of the second, Valvata, Paludina and Ampullaria : of the third, Navicella, Neritina, Nerita, and

TABLE 21. Natica. The families Janthinea, Macrostomala, Plicacea, Scalariana, and part of the Turbinacea, are also in this compartment. The first has but one genus, Janthina: the second, the genera Sigaretus, Stomatella, Stomatia, Haliotis : the third, Tornatella, Pyramidella : the fourth, Vermetus, Scalaria, Delphinula : the fifth, Solarium, Rotella, and Trochus.

TABle 22. Monodonta, Turbo, Planaxis, Phasianella, and Turritella. Amongst the Scalaria, is the costly and beautiful shell $S$. pretiosa 
tiosa (Turbo sealaris. Lin.), or Wendel trap. Room viII. The first genus of the family of the Canalifera, мат. Н Cerithium, is also in this compartment.

TABLE 23. Genera of the Canalifera con. tinued, viz.-Pleurotoma, Turbinella, Cancellaria, Fasciolaria, Fusus, Pyrula, Struthiolaria, Ranella, Murex, and

TABLE 24. Triton, the last genus of this family. In this compartment are also the genera of the family Alata, viz.-Rostellaria, Pterocera, and Strombus.

TABle 25. Part of the family Purpurifera, viz.-the genera Cassidaria, Cassis, Ricinula, Purpura, Monoceros, Concholepas, Harpa, Dolium, and part of the genus Buccinum. From the molluscous animal, inhabiting the purpura, the ancients obtained their celebrated purple dye, which is contained in a bladder-shaped reservoir, situated near the stomach. The species P. patula (Buccinum patulum. Lin.) is said to have afforded the finest colour.

TABlE 26. Buccinum continued, Eburna, Terebra. The next family is Columellaria, two genera of which are in this compartment, viz. Columbella and Mitra. The species Mitra zonalis is an unique shell.

TABLE 27. The genera of the Columellaria continued, viz. Voluta, Marginella, and Volvaria. Also, the first genus of the family Convoluta;-viz. Ovula, amongst which is the $\mathrm{O}$. volva (Bulla volva. Lin.), or Weaver's Shuttle. 
Room viIr. TABLe 28. The Genera Cypræa, Terebellum, Nat. Hist. and Ancillaria, and

TABle 29. Oliva and Conus, of the same family. Amongst the Cyprææ is the rare and beautiful shell the Cypræa aurora (Cypræa aurantium. Gmel.), or orange Cowrie, and several specimens of the species $\mathrm{C}$. moneta, used by the inhabitants of the Coast of Guinea as current money. Amongst the numerous species of the genus Conus, are several fine shells, particularly the C. ammiralis, C. cedo nulli, and the very rare and costly C. aurantius, or orange admiral.

Table 30. The Mollusca Cephalopoda contain the families Orthocera, Lituolata, Cristata, Spharulata, Radiolata, Nautilacea, Ammoneca, Argonautea, and Sepiaria. Many of the genera of these families, the greater number of which are fossil shells, are wanting. Amongst those in this compartment, are Belemnites, Spirula, Miliolites, Rotalites, Discorbites, Nummulites ; some fine specimens of the Nautilus, Ammonites, Orbulites, Baculites, and several of the elegant genus Argonauta, or paper Nautilus. The Loligo, and Sepia or Cuttle fish, are the last genera of this order.

The Mollusca Heteropoda are generally naked and have no shell, except the genus Carinaria, of which Lamarck enumerates three species; C. vitrea, C. fragilis, and C. cymbium. An unique shell of the first species is preserved in the $\mathrm{Mu}$ seum at Paris, of which there is a model, in wax, 
in this compartment. The original was brought воом virr. by M. Huon, one of the officers sent in search Nat. Hist. of La Peyrouse, from the South Seas.

TABLE 31 contains the parts of shells and the products of molluscous animals. A dissected Nautilus, shewing the interior chambers of the shell; one valve of a large Meleagrina margaritifera, or pearl muscle-various specimens of pearls, which are produced by disease in shells. Some of the pearls, in this case, attached to fragments of shell, shew the manner in which the animal may be made to produce apparently fine pearls, by an artificial process. Spherules of shell, or some other substance, flattened at the bottom, are forcibly inserted between the animal and the shell, in such ra way that it cannot displace it-which in a short time is covered with a layer of pearly matter, secreted by the mantle of the animal. Two pair, and a single valve, of extraordinary size, of the Pinna squamosa; the byssus, or beard of the pinna, and a pair of gloves made of the same substance, \&c. This table contains also the Annulata SedenTARIA, or shells of annulated worms; amongst which are the genera Siliquaria, several Dentalia, Magilus, Galeolaria, (both very rare,) Vermicularia, Serpularia, \&c. 


\section{NINTH ROOM.}

Roом Ix. This room is appropriated to petrifactions and Nar. Hist. other fossil organic remains, among which the following may be specified.

Osseous remains of mammiferous animals (CASEs 5 то 12). The more remarkàble are :A fossil human skeleton imbedded in limestone, from Guadaloupe, described in the Philosophical Transactions of 1814.-The bones of several pachydermatous, or thick-skinned animals, viz. those of the several species of Palmotherium and Anoplotherium, from the plaster-quarries in the vicinity of Paris;-those of the fossil Siberian elephant (Elephas primigenius. Bl.), which is the real mammoth; and the gigantic North American animal (MastoDon ohioticus), which has likewise erroneously been called mammoth; - those of the rhinoceros (R. antiquilatis).

Among the bones of the ruminant animals are $:-A$ very perfect specimen of the skull and horns of the large elk (Cenvus giganteus or hibernicus), found fossil in Ireland and in the Isle of Man;-the skull of the Caledonian ox (Bos Taurus, var. gigantea), nearly allied to the European domesticated ox:-bones in the osseous breccia of Gibraltar, and in that of the coast of Dalmatia.

Among those of carnivorous animals may be specified the crania and other bones of the 
cavern bears (Úrsus spelaus, Ursus priscus, URsus arctoideus); and a skull of the cavern ROOM IX. NaT. Hrst. Hyæna (H. spelaca), exhibiting the callus of a healed fracture. These form part of the interesting suite (CASES 7 AND 8.) of osseous remains from the caverns of Sundwig, and of Gaileureuth and Muggendorf in Franconia; as also from the Kirkdale cave in Yorkshire: the latter presented by W. Salmond, Esq.

The scarce remains of birds in this collection (CASE 41 in the window) include some interesting specimens from Oeningen, the plaster-quarries of Paris, and Sheppey, such as the Larus Toliapecus, \&c.

Among the bones of the class of reptiles (in the Cases opposite the fire-place), the most interesting are those of several species of IcHTHyosaurus, a genus of the order of Lizards '(Sauri), to which we have given that name on account of its having been first mistaken for a fish by Chapman and others. Particularly remarkable are the skull and carpal bones of the foot of Ichthyosaurus immanis, (the largest species we are acquainted with) from the blue lias of Lyme Regis, and Bath:- the bones of another huge lizard belonging to a genus intermediate between the Monitor and Guana, from Maestricht; - the unique specimens (CASE 41 in the window,) of Crocodilus priscus, and of LACERta gigantea of Soemmerring (Geosaurus Cuv.). 
Room Ix. In the same table-case is deposited the skeleNAT. HIst. ton of an animal of the salamandrine order (Batrachides), formerly mistaken for human*.

On the same side of the room is deposited a collection of impressions of fishes from Oeningen, canton Glarus, Monte Bolca, \&c. together with a series of palates, sharks' teeth, \&c.

The Cases 16 то 23 contain fossil remains of spiniferous zoophytes (Echinodermata), viz.-

Case 16, and Part of 17 , species of the genera Echinus (Urchin), and Echinocidaris (Turban Urchin).-CASE 17, those of Echinocorys (Helmet Urchin).-CASE 18, those of Echinopilium (Cap Urchin).-Case 19 contains the species of Echinonaus (Boat Urchin), Echinobrissus (Brissus Urchin), and EchinoDiscus (Quoit Urchin).-CASE 20, those of Echinanthus (Flower Urchin), and Echinamygdalus (Almond Urchin).-Case 21, those of Echinospatagus (Spatangus Urchin).

CASEs 22 and 23 contain the various genera of the zoophytes commonly called Encrinitest, \&r.

In Cases 24 to 29 are deposited the tubu-

* Scheuchzer's homo diluvii testis et theoscopos! Tiguri. 1726.

+ For the iliustration of the fossil pentacrini, a fine specimen of the recent species (Pentacrinus Asterias) is deposited under a bellglass in the S.W. corner of this room. The vertebra of a similar fossil species being known by the appellation of Asterias or Starstone, Linnæus derived from it the specific name of the recent species, which, however, he erroneously referred to the genus IsIs. 
lated, cellular, and corticated Polypes. Of the tubulated polypes (CASE 26) the principal geroom IX. NaT. Hrst. nera are Tubipora and Polystomus (formerly Turip. serpens). - Among the cellular polypes (Cases 26, 27) are the genera Cellepora, together with Lunulites, Orbulites, \&c.- - The remaining cases contain the various genera of that section of the corticated polypes which comprises the Madrepores, such as Cyclolites, Aspidiscus, Turbinolia, Fungia, Caryophylleea, Madrepora, Astrasa, Hydnophora, with some other undescribed genera.

In CASES 30 то 37 a considerable suite of fossils, mostly belonging to the Alcyonia and Sponges.

Cases 38 and 39 are chiefly occupied by fos. sil remains of the class Crustacea, divided into various genera, and including the order of Trilobites of which the principal genus is that of CaLYMMane, familiarly known by the appellation of the Dudley Fossil; with the related genera Belonurus and Limulus. To these are added (in CASE 39) remains of insects (chiefly of the order of Neuroptera) from the marl slate quarries of Oeningen, \&c.

Cases 42 and 43 (near the window) contain, among other interesting vegetable remains, an extensive collection of fruits and seeds from the blue clay of the cliffs in the Isle of Sheppey, and impressions of leaves and other parts of plants, in bituminous marl slate from Oeningen, \&c.

TENTH 


\section{TENTH ROOM.}

\section{BRITISH ORYCTOGNOSTIC COLLECTION.}

Room $x$. This room contains the rudiments of a collecNaт. HIst. tion of British simple mineral substances. In a series of table-cases are deposited the minerals of the first seven counties of England, in alphabetical succession, from Bedfordshire to Devonshire inclusive. The names of the counties are on the upper part of these table-cases, the contents of which are disposed, by longitudinal and parallel divisions, into four classes, viz. Earths, Metals, Inflammable Substances, and Salts. These divisions (as soon as convenient room shall be obtained) are to be continued, in the same direction, through the whole series of table-cases, so that it may be ascertained at one view, if any, and which of the substances belonging to those classes, are to be met with in any given part of Great Britain.

The upright cases next to the windows, contain coal-fossils, \&c. continued from Room IX.

\section{ELEVENTH ROOM.}

ROOM XI. The lower cases round three sides of this NaT. Hrst. room contain the Collection of British Birds.

The first order consists of the Accipitres, or Predaceous Birds (CASEs 1 To 6): it contains the genera Falco and Strix (eagles, falcons, haroks, and owls). Among the species of the 
first genus may be distinguished two races : one ROOM XI. of them comprehending those birds named Noble, NaT. HisT. the greater portion of which were used in falconry, such as the peregrine falcon (including the supposed species named the starry, the blueback falcon, and the lanner of British writers), the hobby, the merlin (including what is called the stone falcon), the kestril, and the gerfalcon (of which the islandic and rohite gerfalcons are only varieties of plumage). Among the other species of this genus are the golden eagle (adult, and in that state of plumage in which it is called the ring-tailed eagle, together with the chick in two states of growth), the cinereous sea eagle (the varieties of which have been distinguished as two species, named the rwhite-tailed and common or cinereous eagle), the goshawek (young of the second year, in which state only it appears to have been noticed in England), the honeybuzzard (in three different states), the roughlegged buzzard (of which the rough-legged falcon is only a variety), the ash-coloured and the common or hen-harrier (the female of which is the ring-tail of authors). The species of the genus Strix, the nocturnal birds of prey of this order, consist of the snoroy orol, or harfang, the aluco $\mathrm{orol}$, the rohite, the short-eared, and the little orol, or cheveche.

The second order PICI (CASE 7, upper shelves) is composed of birds with climbing feet, with ambulatory, and (in the Linnæan phrase) with 
Rоом XI. gressorial or stepping feet: of the first division Nat. Hrst. are the rood-peckers, and the wry-neck; in the second we have the nut-hatch (partaking of the general character of the rood-peckers and the tit-mice), the hoopoo, and the creeper; in the third the bee-eater (a specimen of which was lately killed in Devonshire) and the king's fisher. The third order, Coraces or Ravens (CASES 7 AND 8, lower shelves), comprises those with scansorial or climbing feet, to which belongs the cuckow, of which Europe possesses but one species, so remarkable for neglecting its young; and those with ambulatory feet, among which are the raven and carrion crows, the rook, the jackdaw, magpie, jay (with its white variety, considered by some authors as a distinct species), the nut-cracker; all which belong to the Linnæan genus of Cortus; - the roller. To these are added the species of Lanius, referred by some to the predaceous, by others to the passerine birds: the great ash-coloured and redbacked shrike, and the rood-chat.

In the fourth order (PASseres, or Passerine Birds, Cases 8 and 9) are placed the starling; showing its change of plumage (amongst which the solitary thrush of Montague is included); the water-ouzel; the rose-red thrush, the misselthrush, the throstle, the fieldfare, the redwing, the ring-ouzel, the black-bird; the Bonemian chatterer; the buntings; the bulfinch, with the greenfinch, hawinch, and crossbill; the finches including 
including the sparrows; the larks, together with ROOM XI. the species of Anthus, separated by Bechstein NaT. Hrsт. from the real larks; two species of fly-catcher; a considerable number of species of the genus Sylvia, among which are the reed-warbler, the nightingale, the hedge-warbler (or, as it is im. properly named, the hedge-sparrow), the blackcap (often named the Welsh or mocle nightingale), the Dartford warbler; the stone and whin chats; the gold-erest, the smallest of the British birds, \&c. the white and grey wagtail; the titmice.

In the fifth order, the Cuelidones or Srallows (CASE 9, bottom shelf), are placed the goatsucker, the swift, the martin, the sand-martin, and chimney-swallow.

The sixth order, the GALIIN \& or Gallinaceous Birds (Cases 10 AND Part of 11), comprehends the columbine or pigeon tribe (referred by Linnæus to the Passeres), and the Gallinæ properly speaking. Of the former we have the stock-pigeon, the ring-pigeon, and the turtle-dove; the latter includes the various kinds of game denominated grouse, partridge, and quail; such as the cock of the wood, a bird no longer an inhabitant of Britain: black grouse; white and red ptarmigan; common partridge, and common quail. To these are added the lusturds, which, with regard to their habitudes, appear to be intermediate between this and the following order.

The seventh order comprehends the Gralle, or waders (CASES 12 To 15); among which may 


\section{6}

ROOM XI. be specified the spoonbill (now seldom seen in NAT. Hist. this country), and the storks, with the herons and bitterns; the curleres, with the ibrs, snipes, ruff, sanderling, \&c.; the plovers, with the lapwing, oyster-catcher, \&c.; the rails, with the crake, gallinule, \&c.

The eighth order, entitled Anseres, or webfooted birds (CASES 16 To 22), contains the grebes, with the guillemots, divers, \&c; the gulls and terns; the petrels; the auks; the puffin; the pelican tribe, with the cormorant, shag, and gannet; the merganser or goosander; the geese and ducks; comprising the rild swan, the redbreasted, clakis and brent, bean and white-fronted, geese; the eider duck, from which the down is obtained, and the various other ducks, such as the scoter, pochard, shoveller, shieldrale, pintail, wigeon, teal, \&c.

The collection of eggs is arranged along with the birds, in separate glass-cases, their numbers corresponding to those affixed to the birds.

CASES 23 AND 24, in the window-seat, contain nests, windpipes, and other parts of various British birds, and in the cases below them are placed the nests of British birds.

\section{ALPHABETICAL LIST OF THE ENGLISH NAMES OF THE BIRDS IN THIS ROOM.}

Auk, 182. 207

Avoset, 169

Bean Goose, 216
Bee-eater, 33

Bittern, 134

Blackcap, 35. 105

Blackbird, 55
Black Cock, 120

Brambling, 69

Brent Goose, 219

Bultinch, 63 
Buntings, 57-61

Bustards, 125-127

Butcher Birds, 24, 25

Buzzards, 12-14

Chaffinch, 68

Cheveche-owl, 21

Chimney Swallow, 110

Clakis Groose, 218

Cock of the wood, 119

Coot, 175

Cormorant, 210

Corvorant, 210

Courland Snipe, 147

Colemouse, 104

Crake, 171

Creeper, 35

Crows, 36-42

Crossbill, 62

Cnckow, 46

Curlew, 138

Divers, 183. 185

Dotterell, 165

Ducks, 222-238

Dunlins, 140, 141

Eagles, 6.8

Eider Duck, 230

Falcons, 1-

Fieldfare, 51

Field lark, 78

Fly-catchers, 79, 80

Fulmar, 203

Gadwall, 224

Gannet, 213

Garganey, 228

Gallinules, 171-174

Geese, 216-218

Gerfalcon, 1

Goat-sucker, 114

Godwit, 154

Golden-eye, 236

Goldfinch, 73

Goosander, 214

Goshawk, 9

Gray, 223

Grebes, 176-179

Greenshanks, 152

Greenfinch, 65

Grossbeak, 64

Gronse, 119. 122

Guillenots, 180, 181

Gulls, 192-203

\section{Harfang, 18}

Harrier's, 16, 17

Hawfinch, 64

Hedge-Sparrow, 99
Hedge-Warbler, 99

Henharrier, 16

Herons, 131-135

Herring Gull, 194

Hobby, 3

Honey Buzzard, 14

Hoopoo, 34

Ibis, 137

Jack Snipe, 158

Jackdaw, 40

Jay, 43

King's-fisher, 32

Kite, 11

Kittewake, 197

Kestril, 5

Knots, 142-145

Larks, 74-78

Lapwing, 161

Linnet, 70

Magpie, 41

Martin, 111

Merlin, 4

Missel Thrush, 50

Moor Buzzard, 15

Mountain Linnet, 71

Nightingale, 84

Nutcracker, 44

Nuthatch, 31

Nyroca Duck, 238

Osprey, 7

Owls, 17-22

Oyster-catcher, 167

Partridge, 123

Pettychaps, 87

Petrels, 203-206

Phalarope, 168

Pintail, 224

Pipits, 76-78

Plovers, 164-166

Pochard, 235

Ptarmigan, 122

Puffin, 209

Pure, 141

Quail, 124

Razor-bill, 208

Redbreast, 89

Redpole, 70

Redshanks, 148

Redstart, 90

Redwing, 53

Reed-Wren ;83
Reed-Warbler, 83

Ring Ouzel, 54

Ring Pigeon,115

Roller, 45

Rook, 39

Ruff, 146

Sanderling, 160

Sand Martin, 112

Sand Pipers, 149, 150 $-162$

Scaup-duck, 234

Scoter, 231

Scout, 180

Sea Pie, 167

Sedge Bird, 82

Shags, 211, 212

Shearwater, 206

Shieldrake, 222

Shoveller, 227

Shrikes, 24. 26

Siskin, 72

Skna Gull, 200

Sky Lark, 75

Smew, 215

Snipes, 153-159

Song Thrush,52

Sparrow, 66

Sparrow Hawk, 10

Spoonbill, 128

starling, 47

Stock Pigeon, 116

Stone Falcon, 4

Stonechat, 95

Storks, 129, 130

Swallows, 110.113

Swallow 'Tern, 188

Swan, 221

Swift, 113

Tarrock, 197

Teal, 229

Terns, 186-191

Throstle, 52

Thruslies, 4.9-55

Titlark, 77

Titmice, 103-109

Tree Sparrow, 67

Turnstone, 163

Turtle Dove, 117

Velvet Duck, 231

Wagtails, 100-102

Warblers, 81-99

Water Rail, 170

Water Ouzel, 48

Waxwing, 56

Wheatear, 96

Whinchat, 94

Whitethroat, 86
ROOM XI.

Nat. Hist. 
ROOM XI. Wigeon, 220 NAT.HIsT。 Wimbrel, 139
Woodpeckers, 27.29 Woodcock, 155 Woodlark, 74
Wood Wren, 93

Wrens, 97, 98

Wryneck, 30

In the upright Cases in the centre of the room are placed the birds collected in the Northern Expeditions, and those presented by the Hudson's Bay Company.

In the glazed Cases, over the British Birds, are placed (until greater space will admit of a more convenient arrangement) the larger species of Mammalia, and in the upright Case between the windows the smaller are deposited.

Over the Case between the windows is placed a Porpoise caught in the Thames, and the coriaceous Turtle, described by Pennant in his British Zoology, caught on the Dorsetshire coast.

The $\mathrm{T}_{\mathrm{ABLE}}$ in the middle of this Room contains a selection illustrative of the orders and genera of the class Insecta, or Insects.

Case 1 begins with the Coleoptera, or beetles.

(A) contains the families Cicindelidæ, Carabidæ (ground beetle), and Dyticidæ, the water beetle.

(B) the families Buprestidæ, Elateridæ (spring beetles), Telephoridæ, Silphiadæ (the burying beetle), Lucanidæ (the stag beetle), \&c.

(C) the Geotrupidæ, Copridæ, and Scarabæidæ. In this last family will be seen the ce- 
lebrated sacred beetle of the Egyptians (Scarabæus sacer of Linnæus); Orchytes rhinoceros, or ROOM XI. rhinoceros-beetle, Dynastes Hercules, Hercules beetle, several interesting species of the Cetonidæ, and many genera of the Heteromera. To the family Curculionidæ belong the diamond beetle, the palm Calandra, \&c.

\section{C.ASE 2.}

(D) Begins with the Prionidæ, and contains many beautiful species of the Cerambycidæ, or capricorn beetles, Crioceridæ, Chrysomelidx, the Cassida, or tortoise beetle, \&c.

To the order Dermaptera belongs the Forficula, or earwig: a specimen will be seen with the wings expanded.

(E) In this division are arranged the orders Orthoprera and Dictyoptera. To the former belong the Phasma, or walking-stick insect, the Mantis, locust, grasshopper, mole, cricket, \&c. The Dictyoptera consisting of the Blatta of Linnæus, or cock-roach.

(F) Hemiptera, containing the Cimex of Linnæus, together with the Nepa, or waterscorpion, Notonecta, boat-fly, \&c. Among the Omoptera will be seen the Cicada, Fulgora, candle-fly, \&c.

\section{Case 3.}

( $G$ H I) Containing the Lepidoptera, or butterflies, hawk-moths, and moths. 


\section{Case 4.}

room XI. (J) Order Trichoptera, genus Phrygania of NaT. Hrst. Linnæus, the caddis worm, or cad-fly, with se. veral specimens of its cases. Neuroptera : in this order are the Libellula, or dragon.fly, Ephemera, day-fly, Myrmelion, ant-lion, \&c.

(K) Hymenoptera, containing specimens of Tenthredo, saw-fly, ichneumon flies, Cynips or gall fly, Chrysis, the ruby-tail Sphex or savage, Formica, the ant, Vespa, wasp, and Apis, the bee.

(L) The order Diptera contains the Culex, or gnat, Tipula, the crane-fly, Stratiomys, cameleon-fly, Tabanus, Rhagio, Mydas, Asilius, Bombylius, the sword-fly, and Ostrus, the botfly. The order Omaloptera (genus Hippobosca, Linnæus) contains the swallow, sheeptick, and forest-fly. 
GALLERY OF ANTIQUITIES.

\section{FIRST ROOM.}

\section{TERRACOTTAS.}

All the Articles in the following Catalogue of Antiquities, unless where it is otherwise specified, belonged to the Collection of the late Charles Towneley, Esq. More ample descriptions, with Plates, of the Antiquities contained in the British Museum, are in the course of publication; and references to the six parts already published are affixed to those articles which have been therein engraved.

Over the door which fronts the entrance into ROOM I. this room, is a bust of Charles Towneley, Esq. Antrquities. to whose profound knowledge of ancient Sculpture, and zeal in the acquisition of the finest specimens of it, the nation is indebted for the formation of a considerable part of the splendid collection of Terracottas and Marbles contained in this gallery. The bust was presented by his uncle, John Towneley, Esq. It is executed in marble by Mr. Nollekens.

No. 1. A female statue, probably one of the Muses. Pl. IIr.

No. 2. An Amphora. 
Room I. No. 3. A terminal head of the bearded BacAntrouties. chus. Pl. xxxvit. f. 75 .

No. 4. A bas-relief, representing a combat between two Amazons and two Griffins. Pl. Iv. f. 4 .

No. 5. Ditto, representing the head of a Triton, on each side of which is a Cupid riding on a dolphin. Pl. Iv. f. 5.

No. 6. Ditto, representing a group of $\mathrm{Si}$ lenus and Cupid, before whom is a female Bacchante dancing, and playing on the tambourin. Pl. v.

No. 7. Ditto, representing an engagement between one of the Arimaspi and a Griffin; on the left of the combatants is the bust of an athletic figure, armed with a battle-axe. Pl. vi. f. 7 .

No. 8. Ditto, intended by the artist as a companion to No. 7, and to be joined to it in the manner in which it is here seen. The subject in both pieces is precisely the same: the bust, however, in this piece is placed on the right of the combatants, and is armed with a sword and shield. Pl. vi.f. 8.

No. 9. Repetition of No. 6. Pl. v.'

No. 10. A bas-relief, representing a head of Medusa, on each side of which is an eagle in the act of seizing, with its talons, one of the snakes entwined in the locks of her hair. Pl. vir. f. 10 .

No. 11. Ditto, representing a couple of chimæras lapping water out of vessels held to them 
by two youths who are attired in Phrygian ROOM I. dresses, and are each kneeling on one knee. Pl. Antrquitieg. viI. f. 11 .

No. 12. A bas-relief, representing a female, who seems to be overwhelmed with affliction. She is seated, and is resting her head upon her right arm, while her attendants, from the concern visible in their countenances, appear to participate in her sorrow. This bas-relief probably represents Penelope dejected at the departure of Ulysses. Pl. vir. f. 12.

No. 13. Ditto, imperfect, representing a fragment of Medusa's head, on one side of which is a figure of Minerva. Pl. virr. f. 13.

No. 14. Ditto, representing the bearded Bacchus, and a female attendant on Bacchus, each of them holding a thyrsus. From the collection of Sir Hans Sloane. Pl. Ix. f. 14.

No. 15. Ditto, imperfect, representing a head of Minerva, and a head of Jupiter. Pl. Ix. f. 15.

No. 16. Ditto, representing Minerva assist. ing the Argonauts to build the famous ship Argo. Pl. $x$.

No. 17. Ditto, imperfect, representing Venus on the ocean, riding upon a sea-horse. Pl. XI. f. 17 .

No. 18. Ditto, representing Victory pouring out a libation to Apollo Musagetes. From the collection of Sir Hans Sloane. PI. XI. f. 18.

No. 19. Ditto, representing a candelabrum lighted for a sacrifice. On each side stands a 
ROOM I. priestess, who with one hand supports the sacred Axtiquities. fillets which decorate the candelabrum, and with the other hand raises a small portion of her robe, like the figure of Hope, on coins of the Roman Emperors. Pl. xII. f. 19.

No. 20. A bas-relief, representing Machaon, after he has been wounded. He is supposed to be sitting in the tent of -Nestor, who is administering a potion to him, as described in the XIth book of the Iliad. The females in attendance are slaves. Pl. xIr. f. 20.

No. 21. Ditto, representing Bacchus and a Faun; the former holds a thyrsus in his left hand, the latter carries a torch in his right hand, and an amphora on his left shoulder. Pl. XIII.

No. 22. Ditto, representing two Fauns, kneeling, one of them playing upon the tambourin, the other accompanying him with small musical instruments called crotala. Between them is Ampelus, the lower part of whose figure terminates in branches of the vine. Pl. xIv. f. 22.

No. 23. Ditto, representing two of the Seasons, Spring and Summer. Pl. xIv. f. 23.

No. 24. Ditto, representing Victory sacrificing a bull before a lighted candelabrum, which is used as an altar. Pl. xv. f. 24.

No. 25. Ditto, imperfect, representing Perseus cutting off the head of Medusa. Pl. xv. f. 25 .

No. 26. Ditto, representing Victory sacrificing 
ficing a bull before a small altar, which is placed upon a tripod table. Pl. xvi. f. 26.

ROOM I.

No. 27. A bas-relief, imperfect, representing a female Bacchante offering a basket of figs to the goddess Pudicitia. From the collection of Sir Hans Sloane. Pl. xvi. f. 27.

No. 28. Ditto, representing two Fauns gathering grapes into baskets. Pl. xvir. f. 28.

No. 29. Repetition of No. 21. Pl. xiI.

No. 30. A bas-relief, representing Bacchus. leaning on the shoulders of a Faun. At his feet is a panther holding up his mouth to receive the wine which is poured from the vase held in the right hand of Bacchus. Before this group is a female attendant on Bacchus, holding a thyrsus in her hand. Pl. xvir. f. 30.

No. 31. Ditto, representing two Fauns leaning over a large open vessel of wine, as if observing the reflection of their faces on the surface of the liquor. Pl. xvir. f. 31 .

No. 32. Ditto, imperfect, representing a trophy, before which stands a captive attended by a guard, and secured by a chain fastened round his right wrist. Pl. xviII. f. 32.

No. 33. Ditto, representing two Fauns gathering grapes into baskets. From the collection of Sir Hans Sloane. Pl. xxxiv. fo 69.

No. 34. Ditto, representing Paris carrying off Helen, in a car drawn by four horses. Pl. XIX. f. 34 .

No. 35 . 
Rоом I. No. 35. A bas-relief, representing Egyptian Antiquiries. hieroglyphics. Pl. xix. f. 35.

No. 36. Ditto, representing two persons navigating the Nile in a boat. In the fore-ground are a hippopotamus, two crocodiles, some birds, and several plants of the Nymphæa lotus. In the distance are buildings, on the roofs of which are seen three Ibises. The whole of this scenery is viewed through two arches supported by columns. Pl. xx. f. 36.

No. 37. Ditto, imperfect, representing a vase with two handles, on one side of which is a panther leaping up, a thyrsus, and the letter A. Pl. xx. f. 37.

No. 38. A statue of the muse Urania: both the hands are wanting; but, from the position of the arms, it is probable that the figure held a radius in the right hand, and a celestial globe in the left hand. It is three feet ten inches high, and is one of the largest statues that has been found of terracotta. Pl. XxI.

No. 39. An Amphora. From the collection of Sir Hans Sloane.

No. 40. A statue of a muse resting her left arm upon a pile of writing tablets which are placed upon a square column. The right arm is raised towards the neck. The figure, in its present state, is three feet four inches high; the head is lost. Pl. xxir.

No. 41. An Amphora. From the collection of Sir Hans Sloane. 
No. 42. A bas-relief, representing a short ROOM I. naked human figure, with a beard; he holds in Antrquitres. each hand the stem of a plant. On each side of this figure is seated a quadruped, whose head is that of an elderly man, and whose tail terminates in a flower. Pl. xxirr. f. 42.

No. 43. Ditto, representing Cupids supporting festoons of fruit. Pl. xxill. f. 43.

No. 44. Ditto, representing a Faun and a Bacchante dancing, and holding between them the infant Bacchus in a basket used for winnowing corn. Pl. xxIv. f. 44 .

No. 45. Ditto, representing the head of Pan, on each side of which is the head of a Satyr; one of the Satyrs is crowned with branches of the pine, and the other with branches of ivy. Pl. xxiv. f. 45.

No. 46. Repetition of No. 4.5.

No. 47. A bas-relief, representing the Indian Bacchus received as a guest by Icarus. Pl. xxv.

No. 48. Ditto, representing two Fauns riding on Panthers. The hinder parts of the panthers terminate in vine leaves. Between the panthers is a vase with two handles. Pl. Xxvr. f. 48 .

No. 49. Ditto, representing a bull and a lion running in contrary directions. The hind legs of both animals are enveloped in foliage. Pl. xxvi. f. 49.

No. 50. Ditto, representing a lighted candelabrum, which is composed entirely of a plant. The flames issue from the flower, which 
room I. grows upon a long stem. On each side stands Antrqurties, a priestess, with one hand holding up a small portion of her robe (see Nos. 19 and 54), and with the other hand holding one of the branches of the plant. Pl. xxvir. f. 50 .

No. 51. A bas-relief, representing two of the Seasons, Autumn and Winter. Pl. xxviI. f. 51.

No. 52. Ditto, imperfect, representing the goddess Salus feeding a serpent out of a patera. The serpent is twined round the trunk of a tree, from a branch of which are suspended two cast-off skins of the serpent. Pl. xxvirI. f. 52 .

No. 53. Ditto, representing a warrior consulting the oracle of Apollo. Pl. xxvilr. f. 53.

No. 54. Ditto, representing a lighted candelabrum, on each side of which stands a priestess carrying a patera on her head, and holding up a small portion of her robe with one hand. (See Nos. 19 and 50.) Pl. XxIx.

No. 55. A bas-relief, representing Theseus slaying a Centaur. Pl. xxx. f. 55.

No. 56. Repetition of No. 18.

No. 57. Repetition of No. 23.

No. 58. Repetition of No. 50.

No. 59. A bas-relief, representing two Fauns treading out the juice of grapes in a wine-press. On one side is a Faun playing upon the double pipe ; and on the other side another Faun, somewhat aged in his appearance, loaded with a heavy basket of grapes. Pl. xxx. f. 59.

No. 60 . 
No. 60. A bas-relief, representing a chariotrace. Pl. xxxi. f. 60.

ROOM $\mathrm{I}$.

No. 61. Repetition of No. 6 .

No. 62. A bas-relief, representing a mask of Bacchus, between those of a young and an old Faun. Pl. xxxi. f. 62.

No. 63. Repetition of No. 62.

No. 64. Repetition of No. 6.

No. 65. A bas-relief, representing two captives in a car drawn by two horses. The captives have chains fastened round their necks and round their ancles, and the ends of the chains are held by guards walking on each side of the car. Pl. xxxir. f. 65.

No. 66. Ditto, representing a head of Jupiter Ammon, which rests on a flower. The ends of the fillets with which the head of Jupiter is crowned are held on each side by a Faun, who is furnished with wings, and whose figure terminates below in foliage, which curls in such a manner as to give the figure the appearance of a Triton. Pl. xxxir. f. 66.

No. 67. Ditto, representing two Fauns gathering grapes into baskets. Pl. xxxiIr. f. 67.

No. 68. Ditto, representing a figure of Victory standing upon a plant, and supporting the branches of it with her hands. Pl. xxxilı. f. 68.

No. 69. Repetition of No. 33.

No. 70. A bas-relief, representing Victory sacrificing a bull before a tripod altar. Pl. xxxiv. f. 70 . 
ROOM I. No. 71. A bas-relief, imperfect, representing Antraurtirs. Theseus riding at full speed, and cutting off the head of an Amazon, whom he has caught by the hair of her head. Pl. xxxy. f. 71.

No. 72. Ditto, representing Venus carried through the air upon a swan. Pl. xxxv. f. 72.

No. 73. Ditto, representing Cupid pressing Psyche, in the form of a butterfly, to his breast. Pl. xxxvi. f. 73.

No. 74. Ditto, representing Cupid flying, with a palm-branch in one hand and a wreath in the other. Pl. xxxvi. f. 74 .

No. 75. A terminal head of the bearded Bacchus. Pl. Xxxvir. f. 75.

No. 76. A female statue, probably of Thalia, the pastoral Muse. Pl. xxxviIr.

No. 77. An Amphora. From the collection of Sir Hans Sloane.

No. 78. A female statue, the character unknown. The head and lower arms are modern. Pl. xxxIx.

No. 79. A statue of Juno, crowned with an indented diadem. Part of the arms is wanting. Pl. XI.

No. 80-83. Amphoræ of various forms.

Nos. 84, 85, 86, 87, 88. Persepolitan Sculpture. Presented by the Right Hon. Sir Gore Ousely.

Nos. 89, 90, 91, 92. Four bas-reliefs from Persepolis. Presented, in 1818, by the Earl of Aberdeen.

No. 93. 
No. 93. Fragments of a Persepolitan In- room I. scription. Presented, in 1818, by the Earl of Antiquiries. Aberdeen.

\section{SECOND ROOM.}

GREEK AND ROMAN SCULPTURES.

No. 1. A colossal head of Minerva. Pt. 1. Roом II. Pl. I.

No. 2. A funeral urn, ornamented with equestrian and pedestrian combatants. Pt. 1. Pl. II.

No. 3. One of the feet or supports of an ancient tripod table. Pt. 1. Pl. III.

No. 4. A statue of Cupid bending his bow. Purchased, in 1812, at the sale of the late Right Hon. Edmund Burke's Marbles.

No. 5. A fragment of one of the three supports of a tripod bason, composed of the head and neck of a lion. On the forehead are the horns of a goat. Pt. 1. Pl. xII.

No. 6. The capital or upper division of a votive cippus. Pt. 1 . Pl. xIv.

No. 7. The key-stone of a triumphal arch, ornamented with a figure of Victory elaborately hollowed out between the two volutes. This fragment is inserted in a modern pedestal. Pt. 1. $\mathrm{Pl}$. $\mathrm{xv}$.

No. 8. A statue of a canephora, anciently made use of as a column. It was one of the Caryatides which supported the portico of a 
Rоом Ir. small temple dedicated to Bacchus. Pt. 1. Antrquities. Pl. Iv.

No. 9. A candelabrum. Pt. 1. Pl. v.

No. 10. The triangular base of a candelabrum, on the sides of which three Genii hold each a part of the armour of Mars; namely, his helmet, his shield, and his sword. Pt. 1. Pl. vi.

No. 11. A vase, three feet high, with upright massive handles; it is of an oval form, and is ornamented all round with Bacchanalian figures. Pt. 1. Pl. vir.

No. 12. A bronze statue of Hercules, carrying away the apples from the garden of the Hesperides. Pt. 3. Pl. II.

No. 12*. Mithraic group. Brought from Rome, in 1815, by Charles Standish, Esq. from whom it was purchased by the Trustees in 1826.

No. 13. One of the feet, or supports of an ancient tripod table. Pt. 3. Pl. III.

No. 14. A statue of Venus, naked to the waist, and covered with drapery from thence. downwards. It was found in the Maritime Baths of Claudius, at Ostia. Pt. 1. Pl. vin.

No. 15. A bronze statue of Apollo.' Pt. 3. Pl. vir.

No. 16. One of the feet, or supports of an ancient tripod table, executed in porphyry. It represents the head and leg of a panther. Pt. 3. Pl. viII.

No. 17. A vase two feet eight inches high, 
of an oval form, with two upright double handles, ROOM II. which spring from the necks of swans. The Anтrqurties. body of the vase in front is enriched with a group of Bacchanalians. Pt. 1. Pl. Ix.

No. 18. A fountain ornamented with ivy and olive branches. 'The water was conveyed through a perforation on the back part of this monument to a serpent's head, in which a leaden pipe was introduced, part of which still remains in the mouth. Pt. 1. Pl. x.

No. 19. A colossal head of Hercules, dug up at the foot of Mount Vesuvius, where it had been buried by the lava of that volcano. From the collection of Sir William Hamilton. Pt. 1. Pl. XI.

No. 20. A colossal head of Hercules, in a very ancient style of Greek sculpture. Pt. 1. Pl. XII.

No. 21. A statue of the Emperor Hadrian, in a military dress ; the breast-plate is in high preservation, and richly ornamented. Purchased in 1821.

No. 22. A colossal head of Minerva, a specimen of early Greek work. Pt. 1. Pl. xvi.

No. 23. A statue of a Faun. Purchased in 1826.

\section{THIRD ROOM.}

GREEK AND ROMAN SCULPTURES.

No. 1. A bas-relief representing an old Faun room III. struggling with a nymph. Pt. 2. Pl. I.

Antiquities.

No. 2. 
Roov iir. No. 2. A bas-relief, representing a candelaAntrquities, brum. Pt. 2. PI. II.

No. 3. Ditto, representing a funeral column, near which is a statue of the god of Lampsacus. Pt. 2. Pl. III.

No. 4. Ditto, representing Bacchus received as a guest by Icarus. Pt. 2. Pl. Iv.

No. 5. Ditto, representing warriors consulting the oracle of Apollo. Pt. 2. Pl. v.

No. 6. Ditto, in the flat early style of Grecian sculpture. It represents Castor managing a horse. Pt. 2. Pl. vI.

No. 7. Ditto, representing Hercules securing the Mænalian stag, which, at the command of Eurystheus, he had pursued a whole year in the forest of Arcadia. Pt. 2. Pl. viI.

No. 8. Blank.

No. 9. A bas-relief, divided into three compartments. In the upper division, the infant Bacchus is represented riding on a goat; in the middle, a Triton, in attendance on Venus, is seizing a marine bull by the horns; and in the lower division is a company of hunters return. ing home with their spoil. Pt. 2. Pl. Ix.

No. 10. Ditto, representing a festoon of vine branches suspended from the skulls of bulls. In the centre, above the festoon, is a mask of a Faun. It has served as a decoration in the in. side of a circular building. Pt. 2. Pl. $\mathrm{x}$.

No. 11. Ditto, representing the Dioscuri on horseback. 
horseback. From the collection of Sir William Hamilton. Pt. 2. PI. XI.

ROOM III.

No. 12. A bas-relief, representing a Bacchanalian group, consisting of three figures; the first, a Bacchante playing on the tambourin; the second, a Faun playing on the double pipe; and the third, an intoxicated Faun holding a thyrsus. Pt. 2. Pl. XIr.

No. 13. Ditto, representing Victory offering a libation to Apollo Musagetes. From the collection of Sir William Hamilton. Pt. 2. Pl. xıI.

No. 14. Ditto, which has served as an ornament on the outside of a circular building. It consists of a couple of branches issuing from one stem, and curling in opposite directions. Pt. 2. Pl. XIV.

No. 15. Ditto, representing the Centaur Nessus carrying Deianira in his arms. Pt. 2. Pl. xv.

No. 16. Ditto, representing a cow suckling her calf, and drinking out of a circular vessel. Pt. 2. Pl. xvi.

No. 17. Two terminal heads, joined back to back; one of the bearded Bacchus, the other of Libera. Pt. 2. Pl. xvII.

No. 18. A statue of the Goddess of Fortune. Pt. 2. Pl. xvirI.

No. 19. A terminal head of the bearded Bacchus, of very early Greek work. Pt. 2. Pl. xIx.

No. 20. A head of Hippocrates. Pt. 2. Pl. xx.

No. 20*. A Greek funeral monument, with a bas-relief and an inscription. It is to the me- 
ROOM III. mory of a person named Alexander, a native of Antrqutres. Bithynia. 'This marble, brought from Smyrna, was presented to the Museum, in 1772, by Matthew Duane, Esq. and Thomas Tyrwhitt, Esq.

No. 21. A terminal head of Mercury. Purchased, in 1812, at the sale of Antiquities belonging to William Chinnery, Esq. Pt. 2. Pl. XxI.

No. 22. A statue of Venus. Pt. 2. Pl. xxir.

No. 23. A bas-relief, representing the apotheosis, or deification of Homer. The Father of Poetry is seated on a throne at the foot of Mount Parnassus, the residence of the Muses; before the poet is a group of figures offering up sacrifices to him. Above are Apollo and the Nine Muses; and on the summit of the mountain is Jupiter, who appears to be giving his sanction to the divine honours which are paid to Homer. This highly interesting bas-relief was found about the middle of the 17th century, at Frattochi, the ancient Bovillæ, in the Appian road, ten miles from Rome. It was for many years in the Colonna Palace, at Rome, and was purchased for the British Museum in the year 1819.

Nos. 21*, 22*. Two feet covered with sandals. They have belonged to the same statue, and are in beautiful preservation.

No. 23*. A bas-relief, representing a comic and a tragic mask.

No. 24*. Ditto, representing four Bacchic masks. Purchased in 1818.

No. 25*. 
No. 25\%. A tragic mask.

ROOM III.

No. 24. A statue of a Faun. Pt. 2. Pl. xxiv. Antrquities.

No. 25. A terminal head of Homer, represented in an advanced age, with a sublime and dignified character. Pt. 2. Pl. xxv.

No. 26. A bust of Sophocles. Pt. 2. Pl. Xxvi.

No. 26*. A very ancient Greek inscription, known by the title of the "Marmor Atheniense." It relates to a survey of some temple at Athens, supposed to be the Erechtheium. Brought to England by Dr. Chandler, and presented to the British Museum, in 1785, by the Dilettanti Society.

No. 27. A terminal head of the bearded Bacchus. Pt. 2. Pl. xxvir.

No. 28. A statue of a nymph of Diana resting herself after the fatigues of the chase. Pt. 2 . Pl. xxvirr.

No. 29. An entire terminus of the bearded Bacchus, six feet high. Pt. 2. Pl. xxix.

No. 30. A terminal head of the bearded Bacchus. Pt. 2. Pl. $x x x$.

No. 31. A statue of a youth holding with both hands a part of an arm which he is biting. This statue belonged to a group, originally composed of two boys who had quarrelled at the game of Tali, as appears by one of those bones called tali remaining in the hand of the figure which is lost. Pt. 2. Pl. xxxi.

No. 32. A terminal head of Pericles, helmeted, and inscribed with his name. Pt. 2. Pl. xxxir. 
ROom III. No. 33. A statue of a Faun; the trunk of the Antrquties. tree which supports the figure is inscribed with the name of the artist. Pt. 2. Pl. xxxir.

No. 34. A terminal head of Epicurus. Pt. 2. Pl. xxxiv.

No. 35. A terminal statue of Pan playing upon a pipe. Pt. 2. Pl. xxxv.

No. 36. A Greek inscription upon a circular shield, containing the names of the Ephebi of Athens under Alcamenes, when he held the office of Cosmetes. Pt. 2. Pl. xxxvi.

No. 37. A terminal statue, supposed to be that of Venus Architis. Pt. 2. Pl. xxxvir.

No. 38. A circular votive patera; having on one side, within a wreath of ivy, an eagle standing upon a slaughtered hare; on the other side, Cupid sacrificing to the god of Lampsacus. Pt. 2. Pl. xxxvirr.

No. 39. An unknown bronze head, supposed to be that of Pindar. Presented, in 1760, by the Earl of Exeter. Pt. 2. Pl. xxxix.

No. 40. A circular votive patera, with a head of Pan in very high relief, on one side; and on the other, in low relief, a profile head of Silenus, in front of a blazing altar, and a branch of ivy between them. Pt. 2. Pl. xL.

No. 4. 0 *. A torso of Hercules.

No. 41. A Greek sepulchral monument. The bas-relief in front represents a trophy, on one side of which stands a warrior, and on the other a female figure feeding a serpent that is twined 
round the trunk of a tree on which the trophy is ROON III. erected. On the right of these figures is the Axtraurries. fore-part of a horse. An inscription on the top of this monument contains a list of names, probably of those who fell in some engagement. Brought to England by Mr. Topham, in 1725, and presented to the British Museum, in 1780, by the Right Hon. Sir Joseph Banks, and the Hon. A. C. Fraser. Pt. 2. Pl. XıI.

No. 42. A terminal head of Periander. Pt. 2. Pl. xLII.

No. 43. A repetition of No. 33. Pt. 2. Pl. XLIII.

No. 44. An unknown terminal head, probably of a Greek poet. Pt. 2. Pl. xLIv.

No. 45. A statue of Actæon attacked by his dogs. Pt. 2. Pl. Xlv.

No. 46. A terminal head of the young Hercules; it is crowned with the leaves of the poplar. Pt. 2. Pl. xlvi.

\section{FOURTH ROOM.}

\section{GREEK AND ROMAN SCULPTURES.}

No. 1. A bust of Trajan, with the breast Room IV. naked. Pt. 3. Pl. I.

No. 2. A statue of Apollo, of very early Greek work. Purchased, in 1818, at the sale of the Comte de Choiseul-Gouffier's Antiquities.

No. 3. A head of Apollo, of very early Greek work. Pt. 3. Pl. Iv. 
Room Iv. No. 4. A head supposed to be that of ArmiAntrquitres. nius. Pt. 3. Pl. vi.

No. 5. A statue of Thalia, found at Ostia, in the maritime baths of the Emperor Claudius. Pt. 3. Pl. v.

No. 6. A colossal head of Marcus Aurelius, represented in the character of one of the Fratres Arvales. Pt. 3. Pl. Ix.

No. 7. A colossal bust of Lucius Verus, covered with the imperial paludamentum. Pt. 3. Pl. $x$.

No. 8. A group of Bacchus and Ampelus. Pt. 3. Pl. $\mathrm{xI}$.

No. 9. A head of the young Hercules: Pt.3. Pl. xII.

No. 10. A head, supposed to be that of Dione. Pt. 3. Pl. XIII.

No. 11. A statue of Diana. Pt. 3. Pl. xiv.

No. 12. A bust of Hadrian, with the breast naked. Pt. 3. Pl. xv.

\section{FIFTH ROOM.}

\section{ROMAN SEPULCHRAL ANTIQUITIES.}

room v. The objects in this room are figured, and Antrqurtres. more particularly described in "The Description of the Ancient Marbles in the British Museum." Pt. 5.

No. 1. A sepulchral urn, with a bas-relief in front; it appears never to have been used, as it is solid, and without any inscription. Presented, in 1817 , by $W . A$. Mackinnon, Esq.

No. 2. 
No. 2. A sepulchral urn, with an inscription ROom v. to Atimetus. Presented, in 1817, by $W . A$. Antrquities. Mackinnon, Esq.

No. 3. A funeral inscription to $M$. Nævius Proculus. Presented, in 1757, by Thomas Hollis, Esq.

No. 4. A sepulchral urn, with an inscription to Vernasia Cyclas.

No. 5. Ditto, with an inscription to L. Lepidius Epaphras. Presented, in 1817, by W.A. Mackinnon, Esq.

No. 6. Two earthen ollæ, placed in the manner of those which contained the ashes of the slaves and inferior order of the Roman people. The monumental inscription, in front of them, records the names of Anniolena Maxima and Servilia Irene.

No. 7. A sepulchral urn, with an inscription to Pompeius Justinianus.

No. 8. Ditto, with an inscription to T. Titulenus Isauricus.

No. 9. Blank.

No. 10. A sepulchral urn, with an inscription to Fl. Elius Victor.

No. 11. Ditto, with an inscription to Silia Attica.

No. 12. A sepulchral vase, found in a tomb near Naples.

No. 13. A sarcophagus, on the front of which is represented the lamentation of a family over a female corpse.

No. $13 *$. 
RoOM v. No. 13\%. Front of a sepulchral urn, inscribed Antrquities. to Cornelia Servanda and Cornelia Onesime.

No. 14. A sepulchral urn, with an inscription to Serullia Zosimenes.

No. 15. Ditto, with an inscription to P. Licinius Successus.

No. 16. Blank.

No. 17. A sepulchral urn, with an inscription to Cossutia Prima.

No. 18. Ditto, with an inscription to Ti. Claudius Lupercus. Presented, in 1817, by W. A. Mackinnon, Esq.

No. 19. Two earthen ollæ, similar to those described at No. 6. The monumental inscription, placed in front of them, records the names of P. Stenius Rufus and Plosurnia Salvilla.

No. 20. A funeral inscription to Eutychia. Presented, in 1757, by Thomas Hollis, Esq.

No. 21. An Etruscan cinerary urn in baked clay. The bas-relief in front represents the hero Echetles fighting with a ploughshare for the Greeks at the battle of Marathon. Upon the cover is a recumbent female figure.

No. 22. A sepulchral urn, with an inscription to Claudia Fortunata. From the collection of Sir Hans Sloane.

No. 23. A funeral inscription to Lucretia. Presented, in 1757, by Thomas Hollis, Esq.

No. 24. An Etruscan cinerary urn in baked clay. The story of Echetles is represented in 
front (see No. 21.), and on the cover is a re- RоOM $\mathbf{v}$. cumbent female figure. The figures on this Antrquities. monument were originally painted. On the upper part of the urn is an Etruscan inscription in red letters. From the collection of Sir IVilliam Hamilion.

No. 25. A sepulchral urn, with an inscription to T. Sex. Agatha.

No. 26. A sepulchral vase, in alabaster, with an inscription to Flavia Valentina.

No. 27. A sepulchral urn, with an inscription to Junia Pieris.

No. 28. An earthen olla, similar to those described at No. 6. The monumental inscription placed in front of it, records the names of Opilia Faustilla.

No. 29. A sepulchral urn, with an inscription to Coelia Asteris. From the collection of Sir William Hamilton.

No. 30. Ditto, with an inscription to P. Octanius Secundus.

No. 31. A fragment of a testamentary inscription, cut from a sepulchral cippus.

No. 32. A sepulchral urn, with an inscription to Pompeius Locusto, Attilia Clodia, and Pompeius. From the collection of Sir William Hamilion.

No. 33. Ditto, with an inscription to C. Magius Pal. Heraclides.

No. 34. An Etruscan cinerary urn in baked clay. The bas-relief in front represents the single 
Rоом v. single combat between the two brothers, EteoAnriquities. cles and Polynices. The two female figures, who are standing near the combatants, are Furies. An Etruscan inscription is painted in red letters on the upper part of this urn; on the cover is a recumbent female figure. From the collection of Sir William Hamilton.

No. 34*. A sepulchral vase, in yellow alabaster.

No. 35. A sarcophagus, on the fiont of which various figures of Cupid and Psyche are represented.

* No. 36. A sepulchral urn, with an inscrip. tion to D. Albiccus Licinus.

No. 37. A sepulchral urn, with an inscrip. tion to Flavia Eunya.

No. 37\%. A sepulchral vase, in yellow alabaster.

No. 38. A monumental inscription to $\mathrm{Da}$ sumia Soteris.

No. 39. A sepulchral vase, in alabaster. From the collection of Sir William Hamilton.

No. 40. A sepulchral urn, with an inscrip. tion to Isochryses.

No. 41. An earthen olla, similar to those described at No. 6. The monumental inscription, placed in front of it, records the name of Apuleia Tychen.

No. 42. A funeral inscription to Flavia Provincia.

No. 43. A sepulchral urn, with an inscription 
tion to Pilia Philtata. From the collection of Sir Room v. William Hamilton.

No. 44. A funeral inscription to Isidorus. Presented, in 1757, by Thomas Hollis, Esq.

No. 45. A mosaic pavement, discovered in digging the foundation for the new buildings at the Bank of England. Presented, in 1806, by the Directors of the Bank.

\section{SIXTH ROOM.}

GREEK AND ROMAN SCULPTURES.

No. 1. A medallion, representing in profile ROoM vi. the bust of an unknown Greek philosopher. Antiquities.

No. 2. Part of the front of a sarcophagus, representing Achilles among the daughters of Lycomedes.

No. 3. A bas-relief, cut from the end of a sarcophagus; it represents two Fauns punishing a Satyr.

No. 4. Part of the front of a large sarcophagus, representing a marriage.

No. 5. The front of a sarcophagus representing the Nine Muses with their respective attributes.

No. 6. A bas-relief, cut from the end of the same sarcophagus as No. 3. It represents two Cupids and a Faun carrying an intoxicated Satyr. 
Room vi. No. 7. Part of a sarcophagus, representing a Antrquitres. carpentum, or funeral car, drawn by four horses.

No. 8. A medallion, representing in profile the bust of an unknown Greek philosopher. It is similar to No. 1, but of a later time and inferior sculpture.

No. 9. The front of a sarcophagus, representing captive Amazons with their shields and battle axes.

No. 10. A fragment of a sarcophagus, representing Bacchus with a thyrsus in his left hand, and with his right arm thrown over the shoulders of a Faun.

No. 11. A fragment of a magnificent sarco. phagus, representing an elderly man, with a manuscript roll in his hand, which he is reading. Before him stands a Muse holding a mask.

No. 12. The front of a sarcophagus, representing a Bacchanalian procession.

No. 13. Heads of Paris and Helen, in altorelievo.

No. 14. The front of a sarcophagus, representing Genii supporting various pieces of armour. On a shield, in the centre, is an inscription to Sallustius Iasius.

No. 15. A head of Jupiter.

No. 16. A terminal statue of a youth represented with the attributes of Mercury.

No. 17. A votive altar, sacred to Apollo.

No. 17*. A bas-relief, representing a female Bacchante clothed in thin floating drapery, through 
through which the beautiful forms of her body ROOM VI. are perfectly apparent. With one hand, which antrauiries. is held somewhat above her head, she holds a knife, and at the same time secures a portion of her robe which is blown behind her; with the other hand, which is held downwards, she carries the hind quarters of a kid. This piece of sculpture was originally one of the ornamental figures on the triangular base of a candelabrum.

No. 18. A head of Apollo Musagetes, resembling, in the disposition of the hair, and in the character of the face, the head of a Muse.

No. 19. A Greek inscription, being a decree of the people of Athens and of the Piræus, in honour of Callidamas. Presented, in 1785, by the Dilettanti Society.

No. 20. A votive statue of Diana Triformis, with a dedicatory inscription round the plinth.

No. 21. An altar of Roman work, ornamented with Egyptian figures.

No. 22. A bust, inscribed to the memory of Cl. Olympias, by Epithymetus, her freed-man. Purchased, in 1812, at the sale of the late Right Hon. Edmund Burke's Marbles.

No. 23. A funeral monument of Xanthippus, who is represented sitting in a chair, and holding a human foot in his right hand.

No. 24. A statue of a satyr.

No. 25. An altar, on which various Egyptian figures are represented. It is of Roman work.

No. 26. 
rоoм vi. No. 26. A head of an Amazon, in the early Antrquities. style of Greek sculpture.

No. 27. A Greek sepulchral monument, with a bas-relief, and an inscription to Mousis, who was a native of Miletus, and daughter of Argæus. Presented, in 1785, by the Dilettanti Society.

No. 28. A figure of Victory sacrificing a bull.

No. 29. A bust of Hadrian with the imperial paludamentum.

No. 30. A statue of Diana Lucifera, of which the head and arms are lost. It was found at Woodchester, in the county of Gloucester. Presented, in 1811, by Samuel Lysons, Esq.

No. 31. A head of one of the Homeric heroes. It is highly animated, and is looking upwards, apparently in great agitation. Pt. 2. Pl. xxirr.

No. 32. A Greek inscription, originally placed under a statue of Jupiter Urius, which stood within a temple erected to that deity at the mouth of the Pontus. Presented, in 1809, by Miss Mead.

No. 33. A bronze statue of a Roman Emperor, probably of Nero when he was young. The figure is represented in armour, which is most beautifully inlaid. It was found near Barking-Hall, in Suffolk, on the estate of the Earl of Ashburnham. Presented, in 1813, by the Earl of Ashburnham.

No. 34. A bust of Severus with the imperial paludamentum.

Nos. 
Nos. 35, 36, 36*. Three Tiles, in terracotta, Room vi. brought from Athens. The fronts are orna- Antrquiries. mented with a border of the honeysuckle pattern, and in the centre of each is the head of a lion, for carrying off the water. Purchased in 1815.

No. 37. A sarcophagus, in the centre of which is the portrait of an elderly man, placed in the inside of a shield, which is supported by two Genii.

No. 38. A colossal foot of Apollo. Presented, in 1784, by Sir William Hamilton.

No. 39. A figure of Victory sacrificing a bull.

No. 40. A head of Faustina, the wife of Marcus Aurelius.

No. 41. A triangular base of a small candelabrum.

No. 42. A sepulchral cippus, with an inscription to Viria Primitiva.

No. 43. A swan, in red marble.

No. 44. A votive altar, dedicated to Silvanus.

No. 45. A head of Tiberius. Purchased, in 1812, at the sale of the late Right Hon. Edmund Burke's Marbles.

No. 46. A Greek sepulchral monument, with a bas-relief, and an inscription to Isias, who was a native of Laodicea, and daughter of Metrodorus. Brought from Smyrna. Presented, in 1772, by Matthew Duane, Esq. and Thomas Tyrwhitt, Esq.

No. 47. An Eagle.

No. 48. 
Room vi. No. 48. A triangular base of a candelabrum, Antrquiries. the sides of which are ornamented with the attributes of Apollo; namely, a griffin, a raven, and a tripod.

No. 49. A head of Plautilla.

No. 50. A votive altar, dedicated to Diana.

No. 51. A sepulchral cippus, the inscription upon which appears to have been erased.

No. 52. A statue of Libera, holding a thyrsus over her right shoulder, and a bunch of grapes in her left hand: at her feet is a panther.

No. 53. A head of Atys.

No. 54. A head of an unknown female, the hair elegantly bound with broad fillets.

No. 55. A statue of Ceres, crowned in the manner of Isis.

No. 56. A head of Nero.

No. 57. A votive statue of a fisherman, who is carrying a round leathern bucket suspended from his left arm. The head is covered with a mariner's bonnet, and a dolphin serves as a support to the figure.

No. 58. A sepulchral cippus, without an inscription. On the front, beneath a festoon which is composed of fruits and foliage, and is suspended from the skulls of bulls, are two birds perched on the edge of a vase, out of which they are drinking.

No. 58*. A sun-dial. Purchased in 1821.

No. 59. A Greek sepulchral urn, solid, and 
with a bas-relief in front; it is inscribed with the names of Pytharatus and Herophilus. From ROOM VI. the collection of Sir Hans Sloane.

No. 60. A Grecian altar. Presented, in 1775, by Sir William Hamilton.

No. 61. A head of Augustus. Purchased, in 1812, at the sale of the late Right Hon. Edmund Burke's Marbles.

No. 62. A Greek funeral monument of Democles, the son of Democles, with a bas-relief and an inscription in eight elegiac verses. It was brought from Smyrna. Presented, in 1772, by Matthew Duane, Esq. and Thomas Tyrwhitt, $E s q$.

No. 63. A statue of Bacchus, represented as a boy about five years old. The head is crowned with a wreath of ivy, and the body is partly covered with the skin of a goat.

No. 64. The front of a votive altar, with an inscription for the safe return of Septimius Severus and his family from some expedition. The parts in the inscription which are erased contained the name of Geta, which by a severe edict of Caracalla was ordered to be erased from every inscription throughout the Roman empire.

No. 65. A bust of Caracalla; the head only is antique.

No. 65*. A bas-relief, representing the goddess Luna surrounded by the signs of the zodiac. Presented, in 1818, by Col. de Bosset.

No. 66. 
Room vi. No. 66. A votive statue of a fisherman, holdAntrqutries. ing a basket of fish in his left hand.

No. 67. A votive altar sacred to Bacchus. On the front, Silenus is represented riding on a panther.

No. 68. A group of two dogs, one of which is biting the ear of the other in play.

No. 69. An unknown bust, dressed in the Roman toga.

No. 70. A head of a female child. The hair is divided into plaits, which are twisted into a knot on the back part of the head. Some of the red paint, with which the hair was originally coloured, is still visible.

No. 71. A small statue of a muse, sitting on a rock, holding a lyre in her left hand; the plinth is inscribed ErMor $I A$.

No. 72. A small statue of Cupid bending his bow.

No. 73. A bas-relief, representing Priam in the act of supplicating Achilles to deliver to him the body of his son Hector.

No. 74. A small statue of Hercules, sitting on a rock, with the apples of the Hesperides in his left hand.

No. 75. A bust of Gordianus Africanus the elder, dressed in the Roman toga.

No. 76. A head of a child.

Nos. 77, 78. Two tiles in terracotta, brought from Athens; the fronts are painted. Purchased in 1815 .

No. 79 . 
No. 79. The front of the cover of a magnificent sarcophagus. It represents a group of catROONIVI. tle, on one side of which is an old Faun, and on the other a young Faun, both recumbent.

No. 80. A fragment of a mask of Bacchus. From the collection of Sir William Hamilton.

No. 81. A fragment of a colossal foot.

No. 82. A votive foot, with a sandal. Round the foot a serpent is twined, with its head resting on the summit, which terminates a little above the ancle.

No. 83. An earthen vase, which has two handles at the neck, and terminates in a point at the bottom, like an amphora. It was found in the baths of 'Titus, with above seventy others of the same sort; all of them contained the fine African sand, with which, when mixed with oil, the Athletæ rubbed their bodies before they exercised.

No. 81*. A votive foot covered with a sandal, and having a serpent twined round it in the same manner as is described at No. 82.

No. 82\%. A colossal hand.

No. 83\%. A mask of Bacchus.

No. 84. A sphinx, which anciently formed part of the base of a superb candelabrum.

No. 84*. An unknown head. Purchased in 1818.

No. 85. A head of Sabina.

No. 86. A small figure of a recumbent Satyr. 
ROOM VI. Antiquities.

No. 87. A sepulchral cippus, without any inscription. It is richly ornamented on the four siles with festoons of fruit.

No. 88. An Egyptian tumbler, practising his art on the back of a tame crocodile.

No. 89. A sepulchral cippus, with an inscription to M. Cœlius Superstes.

No. 90. An unknown bust of a middle-aged man. The hair of the head and beard is short and bushy; the left shoulder is covered with part of the chlamys; the right shoulder and breast are uncovered. On the plinth is an inscription, signifying that L. Emilius Fortunatus dedicates the bust to his friend.

No. 91. A Greek sepulchral monument, with a bas-relief, and an inscription to Exacestes and Metra his wife.

No. 92. A trophy found on the plains of Marathon. Presented, in 1802, by John Walker, Esq.

No. 93. A sepulchral cippus, with an inscription to T. Claudius Epictetus.

No. 94. A head of Domitia.

No. 95. A small statue of Jupiter sitting. He is represented in his two-fold capacity, as king of the upper and lower regions.

No. 96. A monumental inscription, cut from the front of a sepulchral cippus. It records the name of Claudia Tychen.

No. 96*. A head of Demosthenes. Purchased in 1818 .

No. 97. 
No. 97. A statue 3 feet 10 inches high, воом vi. ending from the waist downwards in a terminus. Antrquiries. In the right hand is a bunch of grapes, at which a bird, held under the left arm, is pecking.

No. 98. A votive altar, with a dedicatory inscription to Bona Dea Annianensis.

No. 99. A head of Jupiter Serapis. The paint with which the face was originally coloured, is still discernible.

No. 100. Greek inscription. Formerly belonging to Col. Rooke, and presented, in 1825, by A. E. Impey, Esq.

No. 101. A Greek sepulchral monument, with bas-relief and an inscription. Formerly belonging to Col. Rooke, and presented, in 1825, by A. E. Impey, Esq.

No. 102. Mercury seated upon a heap of stones.

No. 103. Front of a sepulchral monument.

\section{SEVENTH ROOM. \\ ROMAN ANTIQUITIES.}

No. 1. The front of a tomb, from Delos. Room vir. Formerly belonging to Col. Rooke, and presented, Anтruuries. in 1825, by A. E. Impey, Esq.

No. 2. A bust of a sleeping child, in altorelievo.

No. 3. A fragment of a frieze, representing two Cupids running a race, in cars drawn by 
RoOM vir. dogs ; they appear to have just started from the Antiquities. carceres of a circus.

No. 4. A pig of lead, with the name of the Emperor Domitian inscribed upon it. It weighs 154 pounds. It was discovered, in the year 1731, under ground, on Hayshaw Moor, in the manor of Dacre, in the West Riding of Yorkshire. Bequeathed by Sir John Ingilby, Bart., and presented by his Executors in 1772.

No. 5. Ditto, inscribed with the name of $L$. Aruconius Verecundus. It weighs 81 pounds. It was found near Matlock Bank, in Derbyshire. Presented, in 1797, by Adam Wolley, Esq. and Peter Nightingale, Esq.

No. 6. A large sepulchral cippus, with an inscription to M. Clodius Herma, Annius Felix, and Tyrannus.

No. 7. A pig of lead.

No. 8. The front of a sarcophagus, with a Greek inscription to M. Sempronius Neicocrates.

No. 9. A pig of lead, with the name of the Emperor Hadrian inscribed upon it. It weighs 191 pounds. It was found in the year 1796, or 1797 , in a farm called Snailbeach, in the parish of Westbury, 10 miles SW. of Salop. Presented, in 1798, by John Lloyd, Esq.

No. 10. A pig of lead, also inscribed with the name of the Emperor Hadrian. Its weight is 125 pounds. It was found in Cromford Moor, 
in Derbyshire. Presented, in 1797, by Adam room viI. Wolley, Esq. and Peter Nightingale, Esq. Antiquities.

No. 11. A large sepulchral cippus, with an inscription to Agria Agatha.

No. 12. A circular altar. Formerly belonging to Col. Rooke, and presented, in 1825, by $A$. E. Impey, Esq.

\section{EIGHTH ROOM. \\ EGYPTIAN ANTIQUITIES.}

No. 1. The coffin of an Egyptian mummy, room vilI. sent to England by Edward Wortley Montagu, Antrquities. Esq., and presented to the Museum, in 1766, by His late MAJEsty. In the left hand corner of this case is a conical vessel of baked clay, containing an embalmed Ibis, on the other side is the lid of another mummy case.

No. 2. Two Egyptian Mummies. That on the left hand, which has been elaborately and beautifully ornamented with coloured glass beads, some of which still remain, was taken out of the coffin above mentioned. That on the right hand, the face of which is gilt, and the other parts of the body ornamented with paintings, was taken out of the coffin which will be described in the next number. In the lower part of this case is a small Egyptian coffin of an oblong square form : it contains the mummy of a child. The lid and sides of this coffin are covered with paintings. In this case are also de- 
ROOM VIII. posited three cat mummies, from Mr. Salt's colAntrauities. lection.

No. 3. The coffin of an Egyptian mummy, found in one of the catacombs at Sakkara, about four leagues from Cairo, and sent to England, in the year 1722, by Col. William Lethieullier, who bequeathed it to the Museum by his Will, dated July 23, 1755. On the left are two small coffins, each containing the mummy of an infant. A basket found in a tomb by Sir Frederick Henniker; it contains Egyptian bread or biscuit.

No. 4. A collection of vases, usually known by the name of Canopuses. The lids are severally ornamented with a head of Isis, Osiris, a hawk, a wolf, and a baboon.

No. 5. A collection of Egyptian idols, in bronze : among them are three sistrums.

No 6. A collection of Egyptian idols, in wood;-Egyptian idols of Roman work, apparently of the time of Hadrian;-idols and amulets of the Basilidians, who spread their mysterious doctrines, and practised their magical arts, in Egypt, from the time of Hadrian to the fifth century; Egyptian scarabæi, or beetles, found in mummies; - small idols in basalt.

No. 7. A collection of Egyptian idols in porcelain.

No. 8. Various fragments of small statues in basalt, marble, and alabaster. Among them are 
a few perfect figures, namely, two of Harpo- Room viII. crates, one of a baboon, and another of an Apis. Antreutries. At the bottom of this case is a bas-relief, and some large idols in wood.

No. 9. Seven fragments of stones, and several of pottery, with Egyptian inscriptions. Two tin cases containing rolls of Egyptian Papyrus. A mummy Ibis. From Mr. Salt's collection.

No. 10. Several antiquities of the Aboriginal Mexicans.

No. 11. A frame containing an Egyptian painting, taken from the breast of a mummy.

No. 12. A frame containing the bones of an embalmed Ibis. Presented by the late Sir Jos. Banks.

No. 13. A manuscript, taken from a mummy; it is written on papyrus, in the enchorial characters of Egypt. Presented, in 1805, by Wm. Hamilton, Esq.

No. 14. Fragments of a manuscript on papyrus. Presented, in 1805, by $\mathrm{Wm}$. Hamilton, Esq. 


\section{NINTH ROOM.}

\section{EGYPTIAN SCULPTURES.}

The articles contained in this Room, to which this mark ( $\dagger$ ) is prefixed in this catalogue, were collected by the French in different parts of Egypt, and came into the possession of the English army in consequence of the capitulation of Alexandria, in the month of September, 1801. They were brought to England in February, 1802, under the care of General Turner, and were sent, by order of $\mathrm{His}_{\mathrm{s}}$ late MaJesty, to the British Museum.

Room Ix. The articles placed upon the shelves round Antrquiries. the room, consisting of hieroglyphics and other Egyptian inscriptions, and a few figures, are almost all from Mr. Salt's collection, which was purchased by the Trustees of the British Museum, in the year 1821.

No. 1. Figure of a hawk-headed sphinx, found by Belzoni, in the Temple of Ipsambul. Part of the head has been broken off. From Mr. Salt's collection.

No. 2. An Egyptian monument of granite, found in the palace at Carnak, decorated with six figures in high-relief, holding each other's hands, viz. a male and female on each side, and a female at each end. From Mr. Salt's collection. 
No. 3. Similar to No. 1, but more perfect, ROOM 1x. found at the same place. From Mr. Salt's col- antiquities. lection.

No. 4. Part of the frieze of an Egyptian temple. It is covered with hieroglyphics on both sides. The upper part of the front of this frieze consists of a row of serpents. The corresponding part of the other side, of a row of birds. Presented, in 1766, by His late MaJestr.

No. 5. †An Egyptian obelisk, of black basalt, found at Cairo.

No. 6. †A large Egyptian sarcophagus, of breccia, brought from the mosque of Saint Athanasius, at Alexandria. It is covered with hieroglyphics both within and without.

No. 7. + A colossal fist of very considerable magnitude, found in the ruins of Memphis.

No. 8. A colossal head in red granite, from Carnak, found by Belzoni, in 1818. From $M r$. Salt's collection.

No. 9. tA colossal ram's head, which has formed part of a sphinx.

No. 10. A sitting figure of Isis, with the head of a lioness, over which is the disk of the moon; in her left hand she holds the key of the Nile: discovered, in 1816, by Belzoni. From $M r$. Salt's collection.

No. 11. A Greek inscription on a marble slab of considerable dimensions, brought from the island of Tenos. Purchased in 1818.

No. 12. 
ROOM IX. No. 12. A colossal hawk. Presented, in 1805, Antiquities. by Mr. T. Philipe.

No. 13. A capital of an Egyptian column. Presented, in 1805, by Earl Spencer.

No. 14. The lower part of an Egyptian figure kneeling on a square plinth, round which is a border of hieroglyphics. Presented, in 1812, by His Royal Highness the Duke of York.

No. 15. A tablet of hieroglyphics, found in front of the Great Sphinx. Presented, in 1817, by Captain Caviglia.

No. 16. A manuscript written on papyrus in the enchorial characters of Egypt. Presented, in 1820, by the late Right Hon. Sir Joseph Banks; it was brought from Thebes by G. Belzoni, Esq.

No. 17. A colossal arm, in red granite, belonging to the same statue as the head No. 8. From Mr. Salt's collection.

No. 18. A colossal fist. Presented, in 1805, by Earl Spencer.

No. 19. +An Egyptian figure, the size of life, kneeling on a square plinth, round which is a border of hieroglyphics : the head and arms of the figure are wanting.

No. 20. A small figure of Isis, without a head; she is sitting on the ground, and resting her arms upon her knees. An ear of corn is held in the left hand, and in front of the figure is the head of Orus. Presented, in 1767, by the Earl of Bute.

No. 21 . 
No. 21. A votive column, on which is an inROOM IX scription in Greek to the great God Serapis at Antiquities. Canopus. It was brought from Aboukir. Presented, in 1807, by Dr. Bancroft, Jun.

No. 22. A figure of Isis, the size of life. She is represented sitting on the ground, and resting her arms upon her knees. An ear of corn is held in the left hand, and in front of the figure is the head of Orus.

No. 23. +An Egyptian sarcophagus, in black basalt, slightly resembling in its form the human figure. It has a single border of hieroglyphics round the outside.

No. 24. A sphinx, represented, according to the custom of the Egyptians, without wings. Found in the excavation made in front of the Great Sphinx. Presented, in 1817, by Captain Cariglia.

No. 25. One of the horns of an altar which was found in front of the Great Sphinx. Pre. sented, in 1817, by Captain Caviglia.

No. 26. A small hawk of very coarse work, found in front of the Great Sphinx. Presented, in 1817 , by Captain Caviglia.

No. 27. A fragment of the plaited beard of the Great Sphinx. Presented, in 1817, by Captain Caviglia.

No. 28. A sphinx, represented, like No. 24, without wings. Presented, in 1767, by the Earl of Bute.

No. 29. 
Roou IX. No. 29. A fragment, which was found at the Antrquities. foot of Pompey's Pillar, and is partly covered with hieroglyphics.

No. 30. A fragment of an Egyptian inscription, on papyrus.

No. 31. A stone sarcophagus, discovered in a tomb at Thebes; the paintings with which it is ornamented have been restored. Presented, in 1820, by the Earl of Belmore.

No. 32. tA small mutilated Egyptian figure, kneeling on a broken square plinth.

No. 33. A fragment of an Egyptian deity, similar to No. 10, but the disk has been removed.

No. 34. A large statue of Isis sitting in a kind of chair, and resting the arms upon the thighs.

No. 35. Statue of Isis, with the head of a lioness, on which is the disk of the moon and erect serpent's head; she holds the lotus before her in her left hand, the key of the Nile in her right. From Mr. Salt's collection.

No. 36. Similar to No. 34. The disk and the erect serpent's head have been knocked off from the head of this figure, but in the preceding statue they are entire.

No. 37. Similar to No. 35. From Mr. Salt's collection.

No. 38. A colossal statue of Memnon sitting, of black breccia. His hands are extended flat 
upon the thighs: the front and back of the throne are decorated with hieroglyphics. Found ROOM IX. in 1818, in an excavation in the Temple of Memnon. From Mr. Salt's collection.

No. 39. Similar to No. 35. From Mr. Salt's collection.

No. 40. A large square tablet, of breccia, covered with hieroglyphics. It appears to have been used as a mill-stone for grinding corn. Presented, in 1805, by Earl Spencer.

No. 41. A fragment covered with hieroglyphics. Presented, in 1805, by Earl Spencer.

No. 42. A mutilated Egyptian figure, kneeling, and supporting with both hands an altar, on which a scarabæus is placed. Presented, in 1805, by Earl Spencer.

No. 43. Colossal head of brownish breccia, and three fragments from the same statue. From Mr. Salt's collection.

No. 44. A piece of stone, with figures represented in intaglio. Found in front of the Great Sphinx. Presented, in 1817, by Captain Caviglia.

No. 44. An Egyptian bas-relief, consisting of a double range of figures. The upper range is imperfect, half of the figures having been sculptured upon another stone. The lower range represents some priests armed with knives, with which they are sacrificing bulls. It was found near Sakkara, four leagues from Grand Cairo. Presented, in 1767, by the Earl of Bute.

No. 45 . 
ROOM IX. No. 4.5. A fragment of a porphyry column. Antrquitizs. No. 46. + Similar to No. 34.

No. 47. + A fragment of a large sarcophagus, similar in its structure to Nos. 6 and 69.

No. 48. A lion, very rudely sculptured; it is supposed to have stood on one of the walls between the paws of the Great Sphinx. Presented, in 1817, by Captain Caviglia.

No. 49. The impression of a human foot carved in stone, with the letters $N E K \Phi \odot$ engraved over it. Found in front of the Great Sphinx. Presented, in 1817, by Captain Caviglia.

No. 50. A small lion, found in a temple between the paws of the Great Sphinx. Presented, in 1817, by Captain Cariglia.

No. 51. Fragment of an Egyptian figure seated upon a plinth, with the legs turned inward, and lying one upon the other. The plinth and portions of the dress are covered with hieroglyphics.

No. 52. A small Egyptian figure kneeling upon a square plinth, and supporting with his hands a kind of altar, in front of which, within a sunk tablet, is a figure of Isis. The plinth and front of the altar are covered with hieroglyphics. Presented, in 1771, by Matthew Duane, Esq.

No. 53. The statue of an Egyptian deity, similar to No. 34 .

No. 54. A small Egyptian figure, with a beard, a short apron, and a terrific aspect. He 
is standing upright, holding his arms down- Rоом IX. wards a little apart from the body. The orna- Antiquiries. ment upon the head is peculiar to the representation of this figure. From the collection of Charles Toroneley, Esq.

No. 55. A painted statue, found in a sepulchre near the Pyramids. Presented, in 1817, by Captain Caviglia.

No. 56. An Egyptian monument, in which are sunk two square tablets, one of which is left blank, and in the other are represented two female figures standing side by side. These tablets are surrounded by hieroglyphics. From the collection of Sir Hans Sloane.

No. 57. Colossal head of brownish breccia, similar to No. 43. From Mr. Salt's collection.

No. 58. Egyptian inscription on papyrus. Presented, together with a fac-simile, by Dr. T. Young.

No. 59. A piece of stone, with hieroglyphics, found in front of the Great Sphinx. Presented, in 1817, by Captain Caviglia.

No. 60. A head of an Egyptian sphinx. From the collection of Charles Towneley, Esq.

No. 61. A Greek inscription erected in front of the Great Sphinx, by Marcus Aurelius and Lucius Verus. Presented, in 1817, by Captain Caviglia.

No. 62. A figure of Isis seated, holding Orus on her knees; in a hard white stone. Hieroglyphics on the shoulders of the figure, on the sides 
ROOM IX. sides of the seat, and round the pedestal. On Antrquities. her feet are sandals. From Mr. Salt's collection.

No. 63. A Greek inscription erected in front of the Great Sphinx, by Nero. Presented, in 1817, by Captain Caviglia.

No. 64. Lion-headed deity, similar to No. 10, but of inferior workmanship. From Mr. Salt's collection.

No. 65. The Rosetta stone, containing three inscriptions of the same import, namely, one in hieroglyphics, another in the ancient vernacular language of Egypt, and another in the Greek language. These inscriptions record the services which Ptolemy the Fifth had rendered his country, and were engraved by order of the High Priests, when they were assembled at Memphis, for the purpose of investing him with the royal prerogative. This stone was found near Rosetta.

No. 66. The head and upper part of the body of a colossal statue, brought from the ruins of the Memnonium, a building dedicated to Memnon, at Thebes. This fragment is composed of one piece of granite of two colours, and the face, which is in remarkably fine preservation, is executed in a very admirable manner. Presented, in 1817, by Henry Salt, Esq. and the late Louis Burckhardt, Esq.

No. 67. Statue of Isis, in basalt, seated upon a pedestal, her arms crossed upon her knees which are almost as high as her chin. The front of the figure and pedestal are covered with an hieroglyphical 
hieroglyphical inscription. From Mr. Salt's col- Room Ix: lection.

No. 68. An oblong stone, with a shallow excavation in the centre. The top and sides are adorned with hieroglyphics. It was perhaps intended for a pedestal.

No. 69. tA large Egyptian sarcophagus, of black granite, covered with hieroglyphics, inside and outside. This sarcophagus, which was brought from Grand Cairo, was used by the Turks as a cistern, which they called "The Lover's Fountain."

No. 70. †An Egyptian obelisk, of black basalt, found at Cairo.

No. 71. Part of the frieze of an Egyptian temple. It is covered with hieroglyphics on both sides. The upper part of the front of this frieze consisted of a row of birds, the legs of which are all that now remain. Presented, in 1766, by His late Majesty.

No. 72. A trough, in hard breccia, with hieroglyphics; decorated at one end with the figure of an old man seated. From Mr. Salt's collection.

No. 73. A colossal head, in white hard stone. From Mr. Salt's collection.

No. 74. A group of two figures seated with a smaller one between them, in hard sand stone: found in a tomb, and probably represents the man, his wife, and child who were buried therein. The sides of the seat, the ground abont their 
ROOM IX. feet, and a stripe down the front of their lower Antrquitres. garments are decorated with hieroglyphics. The heads and upper parts of the bodies of the figures have been covered with a thick coat of paint, part of which still remains. From $M r$. Salt's collection.

\section{TENTH ROOM.}

\section{GREEK AND ROMAN SCULPTURES.}

Rоoм x. No. 1. A head of Juno, crowned with a broad Antrourties. indented diadem.

No. 2. An upright narrow piece of marble, ornamented with branches of the olive and the vine.

No. 3. A head, apparently of a trumpeter.

No. 4. An unknown female head. The sockets of the eyes are hollow, and have been originally filled with coloured stones, or some other material.

No. 5. A torso of a small statue of Venus.

No. 6. An unknown female head, with a broad fillet across the forehead.

No. 7. A head of a goat.

No. 8. Cupid sleeping upon a lion's skin.

No. 9. An epitaph on a dog. From the collection of Sir Hans Sloane.

No. 10. An unknown head.

No. 11. A head of Apollo.

No. 12. A head of a lion, being a fragment of a large sarcophagus.

No. 13. 
No. 13. An oblong square basin of granite, ROOM X. similar to such as were used in the temples, to Antriquiries. contain the water necessary for the purification of those who sought admittance to the sacrifices.

No. 14. A mask cut from the cover of a large sarcophagus. From the collection of Sir William Hamilton.

No. 15. A terminal head of Libera.

No. 16. A head of a female Bacchante.

No. 17. A case containing a collection of an. tique bronzes.

No. 18. A head of a laughing Faun.

No. 19. Small terminal heads of Bacchus and Libera, joined back to back.

No. 20. A small terminal head of Libera. From the collection of Sir William Hamilton.

No. 21. Ditto, in yellow marble.

No. 22. Ditto, in red marble.

No. 23. A small terminal head of Libera, in reddish yellow marble, with a necklace composed of ivy leaves.

No. 24. Ditto, in white marble, with the breast covered with drapery. From the collection of Sir William Hamilton.

No. 25. A small terminal head of the bearded Bacchus. From the collection of Sir William Hamilton.

No. 26. A small female head, the hair of which is formed of a distinct piece of marble, and is fitted to the head in the manner of a wig. 
ROON X. No. 27. A small head of a young man, covered Antrourties. with a helmet, which is ornamented with the horns of a ram. From the collection of Sir William Hamilton.

No. 28. A small mask of Silenus. From the collection of Sir William Hamilton.

No. 29. A small cylindrical piece of marble, which appears to have been part of the stem of a candelabrum. It is ornamented with four griffins and two candelabra.

No. 30. A fragment of a bas-relief, representing the head of an elderly man. It has the beard on the chin and upper lip, and the hair of the head is short and curly. From the col. lection of Sir William Hamilton.

No. 32. A fragment of a bas-relief, representing a head of Antinous. From the collection of Sir William Hamilton.

No. 33. A votive barrel sacred to Bacchus.

No. 34. A small terminal head of the bearded Bacchus, in yellow marble. From the collection of Sir Hans Sloane.

No. 35. A votive horn, in marble, two feet long.

No. 36. A head of Adonis, covered with the pyramidal hood. The lower part of the face and neck is covered with drapery.

No.37. A head of Jupiter Serapis in green basalt.

No. 38. A small statue of a Muse, sitting on a rock and playing on a lyre.

No. 39. 
No. 39. A head of Jupiter Serapis. From the collection of Sir William Hamilton.

ROOM X.

Antiguities.

No. 40. A piece of mosaic pavement, found at Woodchester, in the county of Gloucester. Presented, in 1808, by Samuel Lysons, Esq.

No. 41. A statue of a Discobolus, who is represented at that precise moment of time which immediately precedes the delivery of the discus. It is an ancient copy in marble, from the celebrated bronze statue executed by Myro.

No. 42. A small bust of Antoninus Pius; the head only is antique.

No. 43. A small scenic figure, sitting on a square plinth. The face is covered with a comic mask.

No. 44. A bust of a child, with the breast naked.

No. 45. A bas-relief, representing the arms of the Dacians and Sarmatians.

No. 46. A bust of an unknown female, represented in the character of Isis. It is gracefully terminated by the flower of the Nymphæa Lotus, on which it appears to rest.

No. 47. A head of a Muse, crowned with a wreath of laurel.

No. 48. A case containing a collection of antique bronzes.

No. 49. A head of one of the Dioscuri.

No. 50. A fragment of a small head of Hercules, covered with the skin of a lion. Presented, in 1757, by Thomas Hollis, Esq.

No. 51. 
ROON X. No. 51. A funeral mask, which was used to Anтrumtres. cover the face of a female corpse. From the collection of Sir William Hamilton.

No. 52. A small head of Hercules. Presented, in 1757, by Thomas Hollis, Esq.

No. 53. A small unknown bust, with a military garment. The head is of yellow marble. Presenled, in 1757, by Thomas Hollis, Esq.

No. 54. A small head of Hercules, very much injured by the decomposition of the marble. From the collection of Sir William Hamilton.

No. 55. The capital of a small column of the Ionic order. From the collection of Sir William Hamilton.

No. 56. A small unknown head. From the collection of Sir William Hamilton.

No. 57. A small head of Vulcan, covered with a cap. From the collection of Sir William Hamilton.

No. 58. A votive mask of a bearded Faun. Presented, in 1765, by Thomas Hollis, Esq.

No. 59. A small unknown female head, the hair of which is tied in a knot behind. From the collection of Sir William Hamilton.

No. 60. A small head of Juno. Presented, in 1757, by Thomas Hollis, Esq.

No. 61. A group representing Venus and two Cupids.

No. 62. One of the handles of a vase. From the collection of Sir William Hamilton.

No. 63. A fragment of a bas-relief, representing 
ing part of a fernale figure. From the collection of Sir William Hamilton.

ROOM X.

Antiquities.

No. 64. A bas-relief, representiing a mask of a Faun.

No. 65. A left foot covered with a sandal.

No. 66. The right foot of a child.

No. 67. A hand of a female, holding a lock of hair. This fragment probably belonged to a statue of Venus, who was represented in the act of wringing the water from her hair. From the collection of Sir William Hamilton.

No. 68. The right hand of a female holding a pipe.

No. 69. A lion's foot, which probably has formed part of a tripod table.

No. 70. The left hand and part of the arm of a female, probably Psyche, holding a butterfly.

No. 71. A lion's foot, which has been applied to the same purpose as No. 69 .

No. 72. The left hand of a female, stretched out upon a fragment of something unknown.

No. 73. The right hand of a youth, holding, apparently, a fragment of a bow. This is probably part of a statue of Cupid bending his bow.

No. 74. The right hand of a child holding the head of a ram.

No. 75. A left foot, covered apparently with linen, round which bandages are fastened.

No. 76. A large votive patera, with a basrelief on each side, one representing Silenus, 
Roou x. and the other a Satyr. From the collection of Antrquities. Sir William Hamilton.

No. 77. A small fragment of a figure holding a bird.

No. 78. The left hand of a child holding a fragment.

No. 79. A torso of a male figure, the arms of which appear to have been raised above the head.

No. 80. A small mutilated figure. The right breast is naked; the other parts are entirely covered with drapery. It has a necklace, from which a scarabæus is suspended.

No. 81. A head of an eagle, which appears to have served as the hilt of a sword. From the collection of Sir William Hamilton.

No. 82. A votive patera, with a bas-relief on each side, one representing a mask of the bearded Bacchus, and the other a panther. From the collection of Sir William Hamilton.

No. 83. A fragment of a serpent.

No. 84. A head of Apollo.

No. 85. A head of Cybele.

No. 86. A head of a lion, which was a part of the same sarcophagus from which No. 12 was taken.

No. 87. A cistern of green basalt, originally used as a bath. On the sides are carved two rings in imitation of handles, in the centre of which is a leaf of ivy.

No. 88. A head of Minerva.

No. 89. A colossal head of Antinous in the character 
character of Bacchus; it is crowned with a Room $X$. wreath of ivy.

No. 90. A head of Diana, the hair of which is drawn up from the sides, and tied in a knot at the top of the head. From the collection of Sir William Hamilton.

No. 91. A fragment of a bas-relief, representing three legs; they have belonged to two figures in powerful action, one of which appears to have been aiming a blow at the other, who is falling. Bequeathed by the late Charles Lambert, Esq. and presented, in 1812, by his Executor.

No. 92. A head of Diana, somewhat similar to No. 90, but of superior work.

No. 93. A small domestic fountain, of a square form, which was used for sacred purposes.

No. 94. A bust of Minerva; the head only is antique. The helmet and the bust, which are of bronze, are, with some variations, copied from an ancient bust of Minerva which was formerly in the Vatican, but is now at Paris.

No. 95. An upright narrow piece of marble, ornamented with branches of the olive and the pine.

No. 96. A statue of an intoxicated Faun.

No. 97. A statue of Mercury, sleeping upon a rock.

\section{ELEVENTH ROOM.}

\section{MEDALS AND COINS.}

This collection, the basis of which was formed Room XI. 
ROOM XI. by the cabinets of Sir Hans Sloane and Sir RoAntiquities. bert Cotton, has been from time to time enlarged by many valuable purchases and donations, but principally by the munificent donation of $\mathrm{H}_{\text {Is }}$ present MaJesty, and by the bequests of the Rev. C. M. Cracherode, and R. P. Knight, Esq. It is comprehended under the three following heads :

\section{Ancient Coins. \\ 2. Modern Coins. \\ 3. Medals.}

The first of these heads consists of Greek and Roman coins.

The Greek coins are arranged in geographical order, and include all those struck with Greek characters, in Greece, or elsewhere, by kings, states, or cities, which were independent of the Romans. With this class are placed likewise the coins of free states and cities, which made use of either the Etruscan, Roman, Punic, Spanish, or other characters.

The Roman coins are placed, as far as it can be ascertained, in chronological order. They consist of the $A s$ and its divisions; Family or Consular coins; Imperial coins struck in Rome; Imperial coins struck in Egypt; Imperial coins struck with Greek characters, in different states and cities subject to the Romans; Imperial coins struck in the Roman colonies; Imperial coins struck with Punic characters; and Contorniates.

The second head, comprising modern coins, 
consists of Anglo-Saxon, English, Anglo-Gallic, RоOM XI. Scotch, and Irish coins, and likewise the coins of Antrourtess, foreign nations. This class is arranged according to the respective countries to which the coins belong, those of each country being kept separate.

The third head, which comprises a class considerably more modern than either of those which precede it, consists of medals struck in our own country, and of those which have been struck abroad. These are arranged in the same manner as the modern coins.

\section{ANTE-ROOM.}

No. 1. In the centre of the Ante-room, at the ANTE-ROOM。 head of the stairs, is placed the celebrated Bar- Antraurties. berini vase, which was for more than two centuries the principal ornament of the Barberini Palace. This vase was purchased of Sir William Hamilton nearly thirty years ago, by the Duchess of Portland, since which period it has been more generally known by the name of the Portland Vase. It was found about the middle of the sixteenth century, two miles and a half from Rome, in the road leading to Frascati. At the time of its discovery, the vase was inclosed in a marble sarcophagus, within a sepulchral chamber under the Mount called Monte del Grano. The material of which the vase is formed is glass: the figures, which are executed in relief, are of a beautiful opaque white, and the ground is in perfect 
ANTE-ROON. fect harmony with the figures, and of a dark Antrquities. transparent blue. The subject of these figures is extremely obscure, and has not hitherto received a satisfactory elucidation; but the design and the sculpture are both truly admirable. This superb specimen of Greek art was deposited in the British Museum, in 1810, by his Grace the Duke of Portland.

No. 2. An ancient painting in fresco, representing deer; it was found in a subterraneous chamber at Scrofano, about sixteen miles from Rome. From the collection of Sir William Hamilton.

No. 3. A bas-relief, in stucco, representing a winged boy, or genius, carrying a pedum across his right shoulder. From the collection of Sir William Hamilton.

No. 4. An ancient painting in fresco, representing a female figure holding a patera, on which a vase is placed. Presented, in 1771, by the Earl of Exeter.

No. 5. An ancient painting in firesco, representing two females seated, in the Arabesque style, on the curling branches of a plant; one of them is holding a vase, the other a tambourin. Between these figures is a bas-relief, in stucco, representing a human head surrounded with ivy, and underneath are two birds drinking out of a well. Presented, in 1757, by Thomas Hollis, Esq.

No. 6. Decorations of Roman armour, found in Britain.

No. 7 . 
No. 7. A Persian sextant. ANTE-ROOM.

Case A. Antiquities. Purchased with $M r$. Antraurtres. Rich's collection in 1825.

Case B. An ancient lyre and two flutes found in a tomb at Athens. Antiquities, found by Sir R. Ker Porter in Persepolis, Babylon, \& c.

Shelves C. Antiquities from Nineveh. From Mr. Rich's collection.

Shelves D. Antiquities from Babylon. From Mr. Rich's collection.

\section{TWELFTH ROOM.}

COLLECTION OFSIR WILLIAM HAMILTON.

Cases 1, 2, 3, 4. Penates or household gods, room XII. in bronze. In the lower part of these cases, Antrquities. are contained some large bronze vessels, one of which, in the form of a round deep patera, is remarkable for the beauty of its handles, which are raised above the edge: they represent two serpents holding an egg in their mouths; underneath the serpents is the ægis of Minerva.

Case 5. A raven, the size of life, and seven large candelabra, in bronze. The raven was presented, in 1777, by Lord Seaforth. It is of the finest workmanship, and has probably accompanied a statue of Apollo.

CASE 6. Specimens of ancient glass. The principal articles are eight cinerary urns. One of them has the leaden covering in which it was preserved; and another contains the burnt bones, 
ROON XII. and the asbestos cloth which prevented the ashes Amtrquitres. of the body from mixing with those of the funeral pile. These articles are accompanied by a great number of lachrymatories, and various other vessels and fragments of vessels, of different forms and colours; the whole of which afford ample proof of the ingenuity of the ancients, and of the great knowledge they possessed in the art of manufacturing glass, and of imparting to it whatever colour or form they chose.

Case 7. A large collection of pateræ, upon which are engravings, principally in outline. In this case are also exhibited the umbo of a shield and the scabbard of a parazonium, both of which are ornamented in like manner with engraved figures. The same case likewise contains two bronze arms, executed in a good style; the largest appears to be of very early work.

CASE 11. Necklaces, ear-rings, armillæ, and various other trinkets in gold, several of which are enriched with precious stones. Among the antiquities of gold in this case are a bulla and a large patera: the latter is embossed with bulls, and was found at Gergenti in Sicily. This case contains also a large collection of scarabæi, and engraved gems, from the collections of Sir William Hamilton, Charles Townley, Esq. and the Rev. C. M. Cracherode. A piece of small mosaic work, and a few specimens of ancient art executed in silver, are likewise among the articles included in this case. 
Case 15. Fragments in terracotta. They con- Room XIr. sist chiefly of small heads, some of which are Antrqurties. well executed, and some are valuable as exhibiting specimens of the Roman head-dresses.

CaSE 16. Small figures, and miscellaneous articles in terracotta.

CASE 17. Hindu, Chinese, and Japanese idols. Case 26. Ditto.

Case 27. Small figures, and miscellaneous articles in terracotta.

Cases 28, 32, 36. Fragments of friezes in terracotta.

Case 37. Specimens of ancient armour in bronze, consisting of helmets, breast-plates, standards, swords, belts, heads of spears, points of arrows, \&c. In the middle division of this case is the Roman helmet which was found at Ribchester in Lancashire.

Case 38. A tripod, a lectisternium, a pair of steelyards, and two very large candelabra, in bronze. The first two articles were presented by Sir William Hamilton, namely, the tripod in 1774, and the lectisternium in 1784.

Cases 39, 40, 41, 42. Miscellaneous antiqui. ties in bronze, comprising scales, knives, pateræ, and simpula ; mirrors, lamps, bells, and mortars; measures and wine-strainers; large vessels for culinary and other purposes; several small candelabra, and other articles.

Cases 43, 44, 45. A large collection of Roman lamps in terracotta. 
room xir. CaSes 46, 47, 48. A large collection of RoAntrquities. man lamps in terracotta.

\section{Cases 49, 50, 51 . Ditto.}

CASE 52. Dice and tali, formed of various substances.

CASE 53. A great variety of tesseræ in ivory, bronze, crystal, agate, and terracotta, many of which were tickets of admission to the theatres. In this case also is a considerable number of styles for writing on wax tablets; pins for the hair; bodkins, and needles both for sewing and netting.

CASE 54. Architectural mouldings in porphyry, part of a frieze in rosso antico, handles of knives, fragments of lectisternia, \&c. \&c.

Case 55. Stamps for sealing casks.

Case 56. A large collection of Roman weights.

Case 57. Votive offerings in bronze.

CASE 58. A brick taken out of the ruins of a large city, supposed to have been Babylon, near the town of Hillah, on the river Euphrates; it has an inscription in unknown characters.

Case 59. Specimens of ancient painting, from Herculaneum.

Case 60. A brick similar to the one in Case 58 .

Cases $61,62,63$. Specimens of bas-reliefs in stucco, from the walls of Herculaneum.

Case 64. Celts.

CASE 65. Various instruments used by the ancients.

Case 66. Celts. 
CaSe 67. A marble patera, fourteen inches ROOM XII. in diameter, found in the ruins of Hadrian's Antrouities. Villa; in this case are also contained specimens of Roman enamel, and inlaid work; and likewise some figs and other vegetable substances, found in a calcined state in the ruins of Herculaneum.

Case 68. Armillæ, or bracelets, and various unknown ornaments in bronze.

CASE 69. A large patera of Oriental jasper, cups of crystal, agate, \&c.

Case 70. Hinges and nails.

CASE 71. Fibulæ, or brooches.

CASE 72. Buckles used by the ancients for different purposes.

CaSE 73. Handles and other parts of vases.

Case 74. Ditto.

Case 75. Specimens of locks and keys.

CaSE 76. Spears, knives, and various instruments in iron.

Case 77. Bits, spurs, and ornaments for harness; fragments of chains, \& c.

Case 78. Some articles in bronze, the uses to which many of them were applied are unknown.

The intermediate and subsequent cases in this Room are filled with Greek vases, of which great numbers were found in sepulchres within those parts of the kingdom of Naples anciently called Magna Græcia. Most of these vases are ornamented with paintings, representing a variety of subjects, chiefly mythological, the compositions 
Room xir. of which are truly elegant. 'The forms of the Aмтrquities. vases are much varied, and are equally simple and beautiful.

\section{THIRTEENTH ROOM. PRINTS AND DRAWINGS.}

Roov XIII. This Room contains an extensive and valuable Antraurties. collection of prints and drawings, the most important part of which was bequeathed by the Rev. C. M. Cracherode.-The contents of this Room, as well as the collection of coins and medals, can be seen only by a few persons at a time, and by particular permission.

\section{FOURTEENTH ROOM.}

ROon xiv. No. 1-23. Bas-reliefs; representing the batAntiquities. tle of the Centaurs and Lapithæ, and the combat between the Greeks and Amazons; they were found in the ruins of the temple of Apollo Epicurius (or the Deliverer) built on Mount Cotylion, at a little distance from the ancient city of Phigalia in Arcadia. These bas-reliefs composed the frieze in the interior of the Cella. The battle of the Centaurs and Lapithæ is sculptured on eleven slabs of marble $(1-11)$. That of the Greeks and Amazons occupies twelve (12-23). The direction of the slabs belonging to the former subject was from right to left; that of the latter from left to right.

A circumstance which adds very much to the interest of these marbles is our knowledge of the precise time when they were executed; for Pausanias, in his description of this temple, in- 
forms us that it was built by Ictinus, an architect ROOM XIV. contemporary with Pericles, and who built the Antrourties. Parthenon at Athens. These marbles are all engraved and more fully described in the fourth part of the description of the Museum Marbles.

No. 24. A fragment of a Doric capital of one of the columns of the Peristyle. From the same temple.

No. 25. A fragment of an Ionic capital of one of the columns of the Cella. From the same temple.

Nos. 26, 27. Two fragments of the tiles which surmounted the pediments, and formed the superior moulding. From the same temple.

No. 28-38. Fragments of the Metopes, found in the porticos of the Pronaos and Posticus, which were enriched with triglyphs. From the same temple.

No. 39. A small tile, which was used for the purpose of covering the joints of the greater tiles; the ornament in front surmounted the cornice. From the same temple.

No. 40. Another tile used for the same purpose, but on the point of the ridge. From the same temple.

THE FOLLOWING ARTICLES CONTAINED IN THIS ROOM FORM A PART OF THE COLLECTION WHICH BELONGED TO THE EARL OF ELGIN.

No. 41. An Egyptian scarabæus, or beetle, brought from Constantinople.

No. 42. An architectural statue; it was one 
ROOM XIV. of the Caryatides which supported the roof Anriqurtres. under which the olive-tree of Minerva was sheltered in the temple of Pandrosus at Athens.

No. 43. A piece of the shaft of an Ionic column.

No. 44. The capital of an Ionic column belonging to the temple of Diana, at Daphne, on the road from Athens to Eleusis.

No. 4.5. A piece of the shaft of an Ionic column, belonging to the same temple.

No. 46. The base of an Ionic column, likewise belonging to the same temple.

No. 47. The capital of an Ionic column, from the portico of the Erechtheium, at Athens. The building to which this singularly beautiful piece of architecture belonged, was a double temple dedicated to Minerva Polias and Pandrosus.

Nos. 48, 49. A portion of the shaft, and the base, of the same column.

No. 50. A solid monumental urn, or cenotaph, with a bas-relief in front, not inscribed:

No. 51. Another monumental urn, of the same kind, inscribed with the name of Phædimus of Naucratis.

No. 52-54. Casts in plaster of three of the metopes of the north side of the temple of Theseus, at Athens. The first represents Theseus killing Creon, king of Thebes; the second, Theseus overcoming Cercyon, king of Eleusis, in a wrestling match, and the third, Theseus killing the Crommian sow.

No. 55-68. Casts in plaster from the frieze 
of the Pronaos of the temple of Theseus. The Room XIV. subject of this frieze is a battle fought in the Antraurties. presence of six divinities, who are represented sitting in the midst of the combatants.

No. 69-73. Casts in plaster from the frieze of the Posticus of the same temple. The subject of these sculptures is the battle of the Centaurs and Lapithæ.

No. 74-88. Casts in plaster of the whole of the frieze at the west end of the Parthenon; these casts are arranged in the order in which the original marbles were placed in the temple.

No. 89-97. Casts in plaster of the frieze of the Choragic Monument of Lysicrates, commonly called the Lanthern of Demosthenes. The subject of this frieze is the story of Bacchus and the Tyrrhenian pirates.

Nos. 98, 99. Casts in plaster, from one of the ends of the celebrated sarcophagus in the cathedral church at Agrigentum, which represents the story of Phædra and Hippolytus. Phædra is here represented surrounded by her female domestics, and plunged into grief at the refusal of Hippolytus, which has just been communica. ted to her. The attendants are endeavouring in various ways to console their mistress, and some of them attempt to alleviate her distress by the sounds of their instruments.

No. 100. A cast in plaster of a portion of the frieze from the east front of the Parthenon. 
Room XIv. The original is in the French collection. PreAntiqurries. sented, in 1820, by Francis Chantrey, Esq.

No. 101. A torso of Venus, of very fine sculpture. Purchased in 1821.

No. 102. Torso of a male figure, in high relief, found in the island of Delos. Presented, in 1819, by Capt. James Murray, R. N.

No. 103. Block of marble, which has probably served as a railpost; on it is sculptured the foot of some animal. It was found at Delos. Presented by Capt. James Murray.

The fragments of mosaic pavement (placed for the present in this room) were found at Withington in Gloucestershire. They were presented, in 1811, by Henry Brooke, Esq.

\section{FIFTEENTH ROOM.}

ALL THE ARTICLES IN THIS ROOM, EXCEPT A FEW WHICH ARE PARTICULARLY SPECIFIED, BELONG. ED TO THE EARL OF ELGIN.

ROOM Xv. No. 1-15. Fifteen of the metopes belonging Antiqurties. to the Parthenon, which, alternately with the triglyphs, ornamented the frieze of the entablature surmounting the colonnade : they represent the battle between the Centaurs and Lapithæ, or rather between the Centaurs and Athenians, who under Theseus joined the Lapithæ (a people of Thessaly) in this contest. In some of these sculptures the Centaurs are victorious, in 
others the Athenians have the advantage, while Room Xv. in others, again, the victory seems doubtful with Antraurres. respect to either of the combatants. These magnificent specimens of ancient art are executed with great spirit in alto-relievo: they were seen at a height of nearly forty-four feet from the ground.

No. 16. A plaster cast of the Metope, No. 7 .

No. 15*-62. The exterior frieze of the Cella of the Parthenon, which embellished the upper part of the walls, within the colonnade at the height of the frieze of the Pronaos, and which was continued in an uninterrupted series of sculpture entirely round the temple. It is in very low relief. The subject represents the sacred procession which took place at the great Panathenæa, a festival which was celebrated every fifth year, at Athens, in honour of Minerva, the patroness of the city. The bas-reliefs which compose this frieze are arranged as nearly as it could be ascertained, and was compatible with the construction of the present room, in the same order as they were originally placed in the Parthenon. Those on the principal front of the temple, namely the east, are placed first, then follow those of the north, and lastly those of the west and south ; they are arranged, in short, in the same manner in which they would be seen by the spectator who approached the temple by the east, and walked round it by the north, west, and south. 
ROOM XV.

Antiquities.

No. 15-21. That portion of the above-mentioned frieze which occupied the east end of the temple. On two of the slabs which compose this part of the frieze are represented divinities and deified heroes, seated; namely, Castor and Pollux, Ceres and Triptolemus, Jupiter and Juno, and Esculapius and Hygeia. There was originally a third slab, which represented four other divinities, also seated, but it has disappeared for many years. On the right and left of these sacred characters, are trains of females with their faces directed to the gods, to whom they are carrying gifts; we see also directors or regulators of the procession, among whom are the officers whose duty it was to receive the presents that were offered. These females appear to have headed the procession, and to have been followed by the victims, charioteers, horsemen, \&c. both on the north and south sides of the temple, which together formed a procession up to the same point in two separate columns.

No. 22-33. A portion of the same frieze, taken from the north side of the temple. No. 22 is a fragment of a much larger slab ; it represents two of the Metcei, or strangers, who settled at Athens, and were allowed to take part in the procession. They carry on their shoulders a kind of tray filled with cakes and other articles. The remainder of this part of the frieze represents charioteers and horsemen. Among the latter are seven slabs, succeeding each other in their 
original order, and which, whether we consider Room Xv. the elegance of the compositions, or the spirit Antreustres. with which the figures of the men and horses are executed, present us with the highest effort of the art of sculpture in the class of low relief.

No. 34-38. Five slabs of the frieze from the north side of the temple; they ought to have been introduced, if the room would have permitted it, between Nos. 24 and 25. Three of these slabs represent charioteers, and two of them horsemen.

No. 38*. A single slab of the north frieze, which serves to fill up a chasm between Nos. 31 and 32 , and to complete the series from No. 25 to 33 inclusive.

Nos. 38**, 38***. Two slabs of the south frieze.

No. 39. A single slab of the frieze from the west end of the temple. It represents 'two horsemen, one of whom is riding before the other, and seems to be in the act of urging his companion to quicken his pace. The direction of these figures is the same as that on the north side, namely, from right to left. There is a peculiarity in the frieze of the west end, which distinguishes it from that on the north and south sides of the temple. The subjects represented on the slabs of those two sides run one into another, that is, what was left imperfect in one slab is completed in the next; whereas in the 
ROOM XV. west end the subjects are nearly complete on Antiquitres. each piece of marble. The western frieze is likewise distinguished from those of the two sides of the temple, by the comparatively few figures introduced into it.

The frieze at the west end of the temple originally consisted of fifteen slabs, of which there is a perfect set of plaster casts preserved in this collection. See Room XIV. (No. 74-88.)

No. 40-62. A portion of the same frieze, namely, that portion which enriched the south side of the temple. It represents a procession of victims, charioteers, and horsemen, and is very similar, in its general character and appearance, to the frieze on the opposite or north side. With respect to the victims, we do not possess any that were on the north side of the temple; but that they formed a part of the procession on that side, as well as on the south, cannot be doubted, since Stuart, in his celebrated work on Athens, has engraved a fiagment of one of them.

No. 63. A group of two of the Fates, from the east pediment of the Parthenon, on which was represented the birth of Minerva. Another figure in this collection (No. 67) is supposed to have been one of the Fates, and to have formed a part of the same group.

No. 64. The upper part of the torso of Neptune, one of the principal figures in the west pediment of the Parthenon. The subject of the sculptures 
sculptures represented on this pediment was ROOM XV. the contest between Minerva and Neptune for Antiquities. the honour of giving name to the city of Athens.

No. 65. The upper part of the figure of $\mathrm{Hy}$ perion rising out of the sea. His arms are stretched forward, in the act of holding the reins of his coursers. This figure, which represents the approach of Day, is from the east pediment of the Parthenon, where it occupied the angle on the left of the spectator.

No. 66. The heads of two of the horses belonging to the car of Hyperion. They are just emerging from the waves, and seem impatient to run their course. From the east pediment of the Parthenon.

No. 67. A female figure, in a sitting posture, also from the east pediment of the Parthenon. This is supposed to be one of the Sister Fates, and to have formed part of the group already described under No. 63 .

No. 68. The head of one of the horses belonging to the chariot of Night, which was represented plunging into the ocean on the right angle of the east pediment of the Parthenon, that is to say, the right angle in reference to the spectator. The car of Day has been already described, as it was represented rising out of the waters on the opposite angle of the same pediment (Nos. 65, 66).

No. 69. The torso of Victoria Apteros, or Victory without wings, who was represented in 
ROOM XV. this manner by the Athenians, to intimate that Antrouries. they held her gifts in perpetuity, and that she could not desert them. This goddess was represented driving the car of Minerva, on the west pediment of the Parthenon; the car approached Minerva, as if to receive her into it, after her successful contest with Neptune.

No. 70. A recumbent statue supposed to be of the river-god Ilissus. The Ilissus was a small stream that ran along the south side of the plain of Athens. This figure, which, with the exception of the Theseus, is the finest in the collection, occupied the left angle of the west pediment of the Parthenon.

No. 71. A statue of 'Theseus, the Athenian hero; he is represented half reclined on a rock, which is covered with the skin of a lion. Theseus, it is well known, professedly imitated the character of Hercules; and it is worthy of remark, that the attitude here given to Theseus is very similar to that of Hercules on some of the coins of Crotona. This wonderfully fine statue originally occupied a place in the east pediment of the Parthenon, next to the horses of Hyperion.

No. 72. A torso of Victory, from the east pediment of the Parthenon. The wings of this figure were probably of bronze: the holes in which they were fastened to the marble may still be seen.

No. 73. A fragment of a group which originally 
ally consisted of Latona with her two children, Apollo and Diana. This group was placed on Antreviries. the right side of the west pediment of the Parthenon. All that remains in the fragment before us, is the lap of Latona, with a small portion of the figure of the infant Apollo.

No. 74. A statue of Iris, one of the daughters of Oceanus, and the messenger of the celestial deities, particularly of Juno. It is from the east pediment of the Parthenon. Iris is represented in quick motion, with her veil inflated and fluttering behind her; and she appears evidently in haste to execute the mission on which she is sent, that of communicating to the distant regions of the earth the important intelligence of the birth of Minerva.

No. 75. A fragment of the statue of Minerva, one of the principal figures in the west pediment of the Parthenon, and of nearly the same proportions as the torso of Neptune, from the same pediment (No.64). This fragment consists of a portion only of the chest of the goddess, which is covered, as usual, with the ægis. The angles of the ægis appear to have been ornamented with bronze serpents, and the centre of it to have been studded with the head of Medusa, of the same metal; the holes in which these ornaments were fastened to the marble are plainly visible. The upper part of the head of this statue is still preserved in the collection. (See No. 118.)

No. 76 . 
Room xv. No. 76. The torso of a male figure, supposed Antiquiries. to be that of Cecrops, the founder of Athens. It is from the west pediment of the Parthenon.

No. 77. A group of two goddesses, probably intended to represent Ceres and her daughter Proserpine; the latter is leaning on the right shoulder of her mother. They are sitting on low seats, which are nearly alike in their con. struction, both of them being furnished with cushions, and ornamented with mouldings of a similar style. This group was in the east pediment of the Parthenon.

No. 78. A small figure of Telesphorus, completely enveloped in a cloak; it wants the head.

No. 79. The chest of a female figure, covered with drapery; it has probably belonged to one of the Metopes of the Parthenon.

No. 80. The capital of an Ionic column, from the temple of Diana, at Daphne.

No. 81. A fragment of a boy, holding a bird under his arm, and feeding it.

No. 81 . A small fragment of a very ancient Greek inscription, written in the bustrophedon manner. Presented, in 1785, by the Dilettanti Society.

No. 82. A bas-relief, representing a young man standing between two goddesses, Vesta and Minerva, who are crowning him.

No. 83. A Greek inscription in the Doric dialect; it is a dedication to Bacclius, by Alexas 
the son of Nicon, and Cephisodorus the son of RoOM XV. Aglaophædas, who had both been victorious in antriquries. the choruses of men.

No. 84. A fragment of a bas-relief, representing an elderly man before one of the gods, probably Bacchus, who appears to hold a vase in his right hand.

No. 85. A piece of the architrave of the Erechtheium, at Athens.

No. 86. A votive Greek inscription of Antisthenes, the priest of Pandion: he was the son of Antiphates, and belonged to the tribe of Pandionis.

No. 87. An imperfect Greek inscription, engraved on three sides of a piece of marble, in very ancient letters. Presented, in 1785, by the Dilettanti Society.

No. 88. A Greek inscription from Athens, signifying that certain gifts, which are specified, had been consecrated to some goddess, probably Venus, by a female who held the office of lighter of the lamps, and interpreter of dreams, in the temple of the goddess. The name of this female, which was no doubt inserted at the beginning of the inscription, is now lost.

No. 89. A fragment of a bas-relief, representing Minerva placing a crown upon a person's head.

No. 90. A small female figure, covered with drapery; it is without a head.

No. 91. A circular votive altar, ornamented 
ROOM XV. with the heads of bulls, from which festoons are Antraurtiez. suspended. The inscription, in Greek, near the bottom, is a prayer for the prosperity and health of a person named Casiniax.

No. 92. A Greek inscription, written in two columns; it contains a list of names arranged in the order of the tribes to which they respectively belonged.

No. 93. An agonistic inscription, in Greek, consisting of the names of those who had conquered in the foot race of the stadium, and double stadium; in wrestling; in boxing; in the pancratium; and pentathlum.

No. 94. A bas-relief, imperfect, representing a goddess seated on a chair or throne, behind whom are seven figures, four of which are children; one of the latter is leading a ram to an altar, the rest are in the attitude of devotion.

No. 95. A fragment of the upper part of a sepulchral stêle.

No. 96. A fragment of a bas-relief; belonging to the frieze of the Parthenon.

No. 97. A bas-relief, representing a votive figure of Cybele, seated in a kind of small temple.

No. 98. A fragment of a bas-relief; belonging to the frieze on the north side of the Parthenon; it is a part of the slab, No. 35.

No. 99. An oblong shallow vessel for containing holy water. The front is ornamented with a bas-relief representing five figures, one of 
which, probably Juno, is seated on a throne: of ROOM XV. the remaining figures, three females are implor- Antrquities. ing the benediction of the goddess in behalf of their children, whom they are carrying in their arms, and a fourth is bringing oblations. From Cape Sigeum, near the plain of Troy.

No. 100. An unknown bust.

No. 101. A fragment of a bas-relief, representing three figures sacrificing before an altar.

No. 102. A fragment of the capital of a Corinthian column: it is ornamented with the leaves of the laurel and acanthus.

No. 103. A fragment of a bas-relief, representing two of the goddesses, Latona and Diana, in procession. Similar bas-reliefs, in a more perfect state, are preserved in the Albani collection. The temple which is here introduced, is probably that of Apollo, which stood in the street at Athens, called "The Tripods."

No. 103\%. A small bas-relief, imperfect, representing Cybele seated. Presented, in 1820, by John P. Gandy, Esq.

No. 104. A fragment of a cinerary urn, on which are represented four figures in bas-relief. The two central figures consist of a young man and woman who are joining hands, and whose names are inscribed above in Greek characters, Demostrata and Callistus. Two other figures are standing by the side of these, in a pensive attitude. 
ROOM XV. Antrqutries. Egyptian idol, in granite; the head is that of a lion, and is remarkable for being ornamented with a crown of serpents, similar to that which is spoken of in the Rosetta inscription.

No. 106. A circular altar, from the island of Delos; it is ornamented with the heads of bulls and festoons in very bold relief.

No. 106 *. A Greek inscription relating to Oropus. Presented, in 1820, by John P. Gandy, Esq.

No. 107. A fragment of a bas-relief, representing a figure standing upright in a dignified attitude; it is probably intended for Bacchus.

No. $107 \%$. The feet of a male statue, on the plinth. Presented, in 1820, by John P. Gandy, Esq.

No. 108. A bas-relief, imperfect; it represents three goddesses, one of whom is seated on a throne.

No. 109. A fragment of a bas-relief, repre. senting part of the body and legs of a boy.

No. 110. A solid urn, or cenotaph, in the front of which two figures, a man and a woman, are represented joining hands. The former is standing, the latter is seated. The names of both were probably inscribed upon the urn, but that of the woman only is preserved, $A d a$.

No. 111. A sepulchral column of Mysta: the Greek inscription informs us that she was a na- 
tive of Miletus, daughter of Dionysius, and wife of Rhaton, who was a native of Thria, a town Antovitres. belonging to the tribe of CEneis.

No. 112. A fragment of a square altar, which has probably been dedicated to Bacchus. The ornaments on two of the sides only have been preserved; these represent female Bacchantes in dancing attitudes. One of the figures holds a shawl or veil in her hands, the other brandishes a thyrsus.

No. 113. A small tile, in terracotta, which has been used to cover the joints of the larger tiles. The front is enriched with a fleuron, and is also inscribed with the name of the maker, Athenæus.

No. 114. An unknown female head, the hair of which is confined within a close elegantly formed cap. The same style of head-dress is observable on some of the silver coins of $\mathrm{Co}$. rinth.

No. 115. The head of a laughing figure, executed in the early hard style of Greek sculpture.

No. 116. The head of a middle-aged man, with a conical bonnet; it appears to have had very little beard, and is most probably the head of a mariner.

No. 117. A head of the bearded Hercules.

No. 118. The upper part of the head of Minerva: the statue to which it belonged formed one of the principal figures in the west pediment 
ROOM Xv. of the Parthenon. This head was originally Antriquries. covered with a bronze helmet, as appears from the holes by which it was fastened to the marble: and the sockets of the eyes, which were originally filled with metal or coloured stones, are now hollow. This fragment of a head, and the portion of a female chest, already described (No. 75), have both belonged to the same statue of Minerva.

No. 119. An unknown bearded head, very much mutilated: it is larger than life, and is crowned with a very thick cord-shaped diadem.

No. 120. A head of the bearded Hercules, similar to No. 117, but of smaller dimensions.

No. 121. A fragment of a head, crowned with vine leaves; it appears to have been executed at a declining period of the arts.

No. 122. An unknown female head, the hair of which is concealed within a close head-dress.

No. 123. A fragment of a bas-relief, representing an unknown female head: from the style of the hair, which is curiously plaited, we may fix the sculpture to about the time of Antoninus Pius.

No. 124. Part of the stem of a candelabrum ornamented with four female figures, one of which is playing on the lyre, and the others, with joined hands, are leading the dance.

No. 125. A fragment of a statue of Hygeia.

No. 126. A fragment of a bas-relief, with part of an inscription.

No. 127. 
No. 127-130. Four pieces of the frieze from ROOM XV. the temple of Erechtheus at Athens; they are Antraurires. enriched with flowers and other ornaments, which are designed with the most perfect taste, and are chiseled with a degree of sharpness and precision truly admirable.

No. 131-147. Fragments of figures, many of which have belonged to the metopes of the Parthenon.

No. 148. A cinerary urn, ornamented in front with four standing figures; two of these, in the centre, are joining hands, the other two are in a pensive attitude. The names of all the figures were originally inscribed on the urn; the first name is not legible; the others are Philia, Metrodora, and Meles.

No. 149. A sepulchral column of Thalia, the daughter of Callistratus, of Aexone.

No. 150. A fragment of a sepulchral stêle; the inscription is very imperfect, but records the name of Musonia. The summit is ornamented with the figure of a butterfly on some fruit.

No. 151. A fragment of a statue covered with drapery.

No. 152. A sepulchral Greek inscription in ten verses, of which the first two and the last two are in the elegiac measure, and the rest are hexameters. The inscription is in memory of a young lady of extraordinary beauty, named Tryphera, who died at the early age of 25 years.

No. 153. A sepulchral Greek inscription, engraved 
Rоон Xv. graved on a piece of entablature. It consists of Antiquites, two lines in prose, and sixteen in pentameter verse. The name of the deceased was Publius Phædrus, a native of Sunium, son of 'Theophilus and Cecropia, and grandson of Pistoteles. The inscription states that he was of noble family, and that his death was followed by the universal regret of the Athenians, on account of his youth, learning, wisdom, and personal accomplishments.

No. 154. A piece of Doric entablature, ori. ginally painted.

No. 155. The upper part of a sepulchral stêle, inscribed with the name of Euphrosynus.

No. 156. A fragment of a colossal female statue, from one of the pediments of the Parthenon; it has belonged to a sitting figure, of which the only remaining part is the left thigh, covered with drapery.

No. 157. A fragment of a decree; the beginning is wanting, and what remains is much mutilated. At the conclusion of the decree it is ordained that the people of Hierapytna in Crete shall affix to it the public seal.

No. 158. A fragment of a bas-relief, on which are represented part of the skin of an animal and the branch of a tree.

No. 159. A fragment of a very ancient Greek inscription from the Acropolis: it contains an account of certain expenses defiayed by those to whom the care of the public games was con- 
fided. The name of the Archon, under whom rоом хv. the stone was engraved, is effaced.

No. 160. A fragment of a bas-relief, representing the fore legs and part of the body of a bull.

No. 161. A fragment of a decree made by a society which is distinguished by a number of epithets, among which are two derived from the names of Hadrian and Antoninus. The society appears to have been formed of musicians, and the decree to have been passed in honour of Bacchus and the Emperor Antoninus Pius. A patera is represented on the upper part of this marble.

No. 162. A fragment of a bas-relief, representing a female figure seated in a chair, with a child standing by her side; the upper part of the woman is wanting. This fragment is probably part of a sepulchral monument.

No. 163. A sepulchral solid urn, ornamented with reeds, and inscribed with the name of $\mathrm{Ti}$ mophon, the son of Timostratus, and a native of Anagyrus, whose inhabitants were of the tribe of Erechtheis.

No. 164. A sepulchral column inscribed with the name of Socrates, son of Socrates, and a native of Ancyra, a city of Galatia.

No. 165. A portion of the cornice from the portico of the Erechtheium at Athens.

No. 166. A fragment of a bas-relief, of large dimensions; it represents Hercules preparing 
Roon Xv. to strike Diomed, king of Thrace, whom he has Antrquities. already knocked down, and is holding by the hair of his head.

No. 167. A sepulchral solid urn, having three figures in bas-relief on the front. The first of these is a warrior with a helmet and a shield, who is joining hands with an elderly man dressed in a long tunic; the third figure is a female. The inscription underneath these figures probably contained the names of the parties, but is too mutilated to admit of being decyphered.

No. 168. A sepulchral column of Menestratus, the son of Thoracides, and a native of Corinth.

No. 169. The upper part of a sepulchral stêle, having the inscription, as well as the arabesque ornament on the summit, perfect. The inscription is to the memory of Asclepiodorus the son of Thraco, and Epicydes the son of Asclepiodorus; both the deceased were natives of Olynthus, a city in Macedonia.

No. 170. A fragment of a Greek inscription; it is too imperfect to admit of a full explanation, but it seems to have been in honour of a person who had distinguished himself on some occasion by great humanity.

No. 171. An amphora.

No. 172. A sepulchral stêle with a Greek inscription, consisting of four lines and a half, part of which is written in prose and part in verse. The inscription informs us that the mo- 
nument was erected by a mother to the memory Room $\mathrm{xV}$. of her two sons, Diitrephes and Pericles, the Antrqurties. former of whom was a soldier of Parium; and also to the memory of her daughter, whose name was Agnes, and that of her brother, Demophoon, who was a soldier of Parium.

No. 173. A fleuron, from the temple of Ceres at Eleusis.

No. 174. A capital of a pilaster.

No. 175. A sepulchral stêle, with an ornament of flowers on the summit. It is inscribed with the names of Hippocrates and Baucis.

No. 176. An Amphora.

No. 177. A Greek inscription, imperfect, but of which fifty-five lines remain. It is written in the Bootian Eolic dialect, and is a treaty between the cities of Orchomenus in Bœotia and Elatæa in Phocis, respecting some payments due from the Orchomenians to the Elatæans. These payments were for the rent of certain pastures which the people of Elatæa had let out to the Orchomenians. The treaty confirms the payment of the stipulated sums, and renews the treaty of pasturage for four years.

Nos. 177*, 178*. Two fragments of the north frieze of the Parthenon; the former is a part of the slab marked No. 35.

No. 178-198. Twenty-one fragments of Greek inscriptions, so imperfect as not to admit of particular description.

No. 199. 
ROOM XV.

No. 199. The celebrated Sigean inscription, Antrautres first published by Chishull, in his " Antiquitates Asiaticæ", and afterwards more correctly by Chandler in his "Inscriptiones Antiquæ." It is written in the most ancient Greek characters, and in the bustrophedon manner, that is to say, the lines follow each other in the same direction as the ox passes from one furrow to another in ploughing. The purport of the inscription is to record the presentation of three vessels, namely, a cup, a saucer or stand, and a strainer for the use of the Prytaneum, or hall of justice, of the Sigeans. The name of the donor was Phanodicus, the son of Hermocrates, and a native of Proconnesus.

No. 200. A Greek inscription, imperfect, engraved in very ancient characters; it seems to be an inventory of some treasures, probably those contained in the Parthenon, and which the Quæstors acknowledge to have received from their predecessors in the same office. The incription not only fills one side of the marble, but also the right edge.

No. 201. The base on which a statue has stood; the feet, which still remain, are very wide apart, and shew that the figure must have been in powerful action.

No. 202. A torso of a male figure, probably that of Iisculapius.

No. 205. A sepulchral column to the memory 
of Callis, who was the daughter of Strato, and a native of the city of Gargettus.

ROON XV.

No. 204. A base of a column, brought from the plains of Troy.

No. 205. A colossal statue of Bacchus, from the choragic monument of Thrasyllus, at Athens. It is a sitting figure covered with the skin of a lion, and with a broad belt round the waist; it was originally placed on the summit of the edifice, at a height rather exceeding twenty-seven feet.

No. 206. A capital of a Doric column, from the Propylæa, at Athens.

No. 207. A piece of the shaft of one of the Doric columns of the Parthenon.

No. 208. A small statue of a Muse, without a head; it was probably intended to represent Polyhymnia.

No. 209. A sepulchral column, inscribed with the name of Callimachus, who was a native of the city of Aexone, and the son of Callistratus.

No. 210. A base of a column brought from the plains of Troy.

No. 211. An Amphora.

No. 212. A sepulchral stêle, with a bas-relief, representing a man clothed in a tunic. The inscription over this figure records the name of Erasippus, who was the son of Callinicus, and a native of CEum in Attica.

No. 213. A sepulchral stêle, in which an equestrian figure, with an attendant on foot, is 
ROOM XV. represented in bas-relief. Above the figures is Antrquitres. an inscription, consisting of three verses, of which the second is a pentameter, and the two others hexameters; they record the name of the deceased, Aristocles, who was the son of Menon, and a native of Piræus.

No. 214. A sepulchral stêle, with a very ancient inscription to the memory of Aristophosa and others. A peculiarity occurs in this inscription, namely, that the letters vo are twice used for vrov.

No. 215. An Amphora.

No. 216. A Greek inscription, imperfect, containing an account of the treasures of some temple, probably those of the Parthenon. The characters which we see on this marble are of a much more modern form than in the inscription of the same kind (No. 200) which we have lately described.

No. 217. The upper part of a sepulchral column, with an inscription to the memory of a person named Simon, who was the son of Aristus, and a native of Halæ in Attica.

No. 218. A fragment of a sepulchral stêle from which the bas-relief has been almost entirely broken away; the inscription is to the memory of Hieroclea, the daughter of Leucius.

No. 219. A votive monument with two Greek verses, signifying that Horarius had dedicated some lamps, which he won in the games, to Mercury and Hercules. The bas-relief above, which 
which probably represented the two deities here ROOM Xv. mentioned, is almost entirely broken away; only Antrquities. the feet of one figure remain.

No. 220. A piece of a frieze, or architectural ornament from the tomb of Agamemnon at Mycenæ. The sculpture is exceedingly ancient, and consists of two kinds of scroll-work, one of which represents the curling of the waves, and the other a series of pateræ which are perfectly flat and plain. The stone is of a brilliant green colour.

No. 221. Another piece of frieze or architectural ornament, from the same place as the last-mentioned article. It consists of three rows of scroll-work, all of which are similar representations of the revolving of the waves. The colour of the stone is bright red.

No. 222. A fragment of a Greek inscription, containing a list of Athenians, with the townships to which they respectively belonged. We read the names of no less than twelve different townships in this small fragment; namely, according to the order in which they occur, Sunium, Ionidæ, Alopece, Pallene, Halæ, Ericea, Colonus, Sphettus, Ceriadæ, Thoricus, Hephæstia, and Bate.

No. 223. A votive Greek inscription, dedicated by some sailors, as a mark of their gratitude to Apollo of Tarsus.

No. 224. A votive Greek inscription, dedicated by Gorgias, the Gymnasiarch.

No. 225. 
Room Xv. No.225. A sepulchral column with an inscripAntroutries. tion to the memory of Theodotus, who was the son of Diodorus, and a native of Antioch.

No. 226. The upper part of a sepulchral stêle, ornamented with leaves and flowers; the inscription is to the memory of Chabrias.

No. 227. A bas-relief, representing two divinities, namely, Jupiter seated on a throne, and Juno standing before him; the latter is removing the veil from her face, as if to address the king of the gods.

No. 228. A very large funeral urn, solid, and without any inscription. It has three figures in bas-relief; the first of these is clothed in a tunic and is seated; the second is a warrior standing up and joining hands with the former ; and the third is a boy carrying a large circular shield.

No. 229. A sepulchral stêle. The bas-relief in front, the lower part of which is broken away, represents two females joining hands, one of whom is seated and veiled, the other standing. Between these appears an old man, clothed in a tunic, and standing in a pensive attitude.

No. 230. A fragment of a Greek inscription; it is the latter part of a decree in honour of a person who had deserved well of some particular city. It is directed, that the decree shall be engraved on marble, and placed in the temple of Neptune and Amphitrite. It appears, from the inscription immediately following, that the city here alluded to was that of the island of Tenos. 
Strabo and Tacitus mention a celebrated temple that was dedicated to Neptune in this island, Anriourries. and it is highly probable that the same temple was dedicated to Amphitrite, as well as to Neptune. Neptune and his symbols frequently occur on the medals of Tenos.

No. 231. A decree of the people of Tenos, in honour of Ammonius, their benefactor : this decree, like the last, is directed to be engraved on marble, and affixed in the temple of Neptune and Amphitrite.

No. 232. A fragment of a decree of the people of Tenos, in honour of some benefactor, whose name is not preserved on the marble.

No. 233. A fragment of a public act of the Athenians; it consists of twenty-one imperfect lines, and seems to relate to the repair of the pavements and roads in the neighbourhood of Athens.

No. 234. A fragment of a public act relating to the people of Athens and Myrina.

No. 235. A bas-relief, representing a Bacchanalian group, found among the ruins of the theatre of Bacchus, on the south-west of the Acropolis. It consists of four figures, each carrying a thyrsus; one of these is Bacchus, dressed in the Indian costume, who with his right hand is holding out a double-handled vase, into which a female Bacchante is pouring wine from a monota, or vase with one handle. On each side of these figures is an elderly Faun, in a dancing attitude, 


\section{6}

ROOM XV. attitude, one of whom is glancing his eye at the Antrqutries. contents of a large vessel of wine placed on the ground.

No. 236. A bas-relief, imperfect, representing a charioteer driving four horses at full speed; a figure of Victory is flying towards him with a crown.

No. 236*. A bas-relief, imperfect, inscribed with the names of Aristodice, Aristarchus, and Athenais, natives of Sestus. Presented, in 1785, by the Dilettanti Society.

No. 237. A solid funeral urn, of large dimensions. It has a bas-relief in front, representing two figures joining hands; these figures consist of a female who is seated, and a man who is standing before her. The Greek inscription gives us the names of both persons: one is Pamphilus, the son of Mixiades, and a native of Egilia; and the other is Archippe, the daughter of Mixiades.

No. 238. A bas-relief, representing Hygieia feeding a serpent out of a patera. She is seated on a throne which is covered with a cushion, and her feet are placed upon a footstool. She wears a high ornament, or tutulus, on her head, and she has a fan, in the shape of an ivy leaf, in her left hand.

No. 239. A solid sepulchral urn, with a basrelief representing five figures, executed in a singularly rude style. The first of these figures is a boy carrying a large circular shield, the 
second is a warrior joining hands with a third Room Xv. person, who is seated before him: the group is Antraurties. completed by the introduction of a child, and of a female whose attitude evinces a dejected state of mind. Over the warrior is the name of Sosippus, in Greek letters.

No. 240. A sepulchral column, inscribed with the name of Anaxicrates, an Athenian, the son of Dexiochus; beneath the inscription is the representation of a sepulchral urn, executed in very low relief.

No. 241. A Greek inscription: it is a prayer in behalf of Euphrosynus.

No. 242. A sepulchral inscription, in six elegiac verses, to a young man of the name of Plutarchus, who died in Ausonia, at a distance from his native country.

No. 243. An architectural fragment, which has formed one of the ornaments of a roof.

No. 244. A part of a colossal foot, probably belonging to a figure in one of the pediments of the Parthenon.

No. 245-251. Seven bas-reliefs, of small dimensions : they represent various parts of the human body, and have been offered up as vows to Jupiter Hypsistos, praying for the cure of diseases in those parts. Some of these bas-reliefs appear to have been presented by the parties in gratitude for cures already received.

No. 252. A fragment of a bas-relief, similar to those just described. The part of the body 
ROow XV. which had received a cure has been broken off; Antrqurties. but the inscription implies, that Syntrophus presents it as a mark of his gratitude to Jupiter Hypsistos.

No. 253. A fragment of a similar bas-relief: the inscription has been broken off, but the part represented is a foot.

No. 254. An architectural fragment, similar to No. 243.

No. 255. A fragment of an unknown female head.

No. 256. The left knee of a colossal statue of very fine work: it has probably belonged to a figure in one of the pediments of the Parthenon.

Nos. 257, 258. Two bas-reliefs, which formed part of the frieze of a temple of the Ionic order (near the Propylæa at Athens), and dedicated to Aglauros. The subject represented on them is a combat between the Greeks and Persians.

Nos. 259, 260. Two bas-reliefs, from the same temple: the combatants appear to be all Greeks.

No. 261-272. Fragments of colossal statues, some of which have probably belonged to figures which stood in the pediments of the Parthenon.

No. 273. A colossal head, much mutilated; it was found in the temple of Nemesis, at Rhamnus, in Attica, and is supposed to be the head of Nemesis. Presented, in 1820, by John P. Gandy, Esq.

No. 274. A sepulchral solid urn, with a basrelief' representing three figures, one of which is 
seated. The inscription presents us with the Room xv. following names: Archagoras, Pythyllis, and Anrreurrues. Polystratus.

No. 275. A sepulchral column, with an inscription to the memory of Biottus, who was the son of Philoxenus, and a native of Diradium.

No. 276. A bas-relief, representing a narrow upright vase with one handle: the form of this vase very much resembles that of the solid urns, so often used by the Greeks as sepulchral monuments.

No. 277. A Greek inscription, imperfect, and very much defaced. It seems to be an inventory of valuable articles contained in some temple.

No. 278. A sepulchral column, inscribed with the name of Botrychus, son of Euphanus, and a native of Heraclea.

No. 279. A fragment of a bas-relief, representing a female sitting.

No. 28 0. A fragment of a Greek inscription: it is a decree of the people of Athens in honour of Hosacharas, a Macedonian. This decree was passed in the Archonship of Nicodorus, in the 3 d year of the 116th Olympiad.

No.281. A fragment of a decree of the Athenians, engraved on a very large piece of marble. So much has been broken away from this inscription, that the precise object of it is not easily collected: it is ordained, however, that the decree shall be fixed up in the Acropolis.

No. 282. 
rоoм xv. No. 282. A fragment of a Greek inscription, Antiquities. engraved in very ancient characters. It seems to be a treaty between the Athenians and the people of Rhegium, a town of the Bruttii, in Italy.

No. 283. A Greek inscription, imperfect, engraved in very small characters: it is an enumeration of the sacred dresses which belonged to some temple.

No. 284. A fragment of a bas-relief, representing a procession of three figures, the last of which carries a large basket on his head: they are accompanied by two children.

No. 285. A sun-dial, with four different dials represented on as many faces. The inscription imports that it is the work of Phædrus, the son of Zoilus, a native of Pæania. From the form of the letters of this inscription, the sun-dial cannot have been made much earlier than the time of the Emperor Severus. It was found at Athens.

No. 286. A fragment of a Greek inscription: it consists of twenty lines of very ancient characters, and seems to be a part of a treaty.

No. 287. A Greek inscription, imperfect.

No. 288. A Greek inscription, relating to the Erythræans : the characters are very ancient.

No. 289. A Greek inscription, imperfect at the end, being a contract respecting the letting of some lands and salt-pits by the people of Piræus. Presented, in 1785, by the Dilettanti Society.

No. 290. 
No. 290. A very ancient Greek inscription, воом xv. which has served as an epitaph on the tomb of Antreurties. the Athenian warriors killed at Potidæa. This inscription, which originally consisted of twelve elegiac verses, has suffered from the injuries of time.

No. 291. A piece of the architrave belonging to the temple of Erechtheus at Athens.

No. 292. A funeral inscription to the memory of Polyllus ; it consists of one line in prose, and two in verse. The line in prose gives us only the name and titles of Polyllus, and the verses intimate that Polystratus had erected a statue to the deceased, and had placed it under the protection of Minerva; the marble on which this inscription is cut, formed a part of the base on which the statue stood.

No. 292*. The upper part of a sepulchral stêle, inscribed with the name of Eumachus, who was the son of Eumachus, and of the city of Alopece. Presented, in 1785, by the Dilettanti Society.

No. 293. A small statue of a boy, imperfect; he is in the attitude of looking up.

No. 294. A fragment of a metope of the Parthenon; it is the torso of one of the Lapithæ.

No. 295. The capital of an Ionic column belonging to a temple of Diana, at Daphne, in the road to Eleusis.

No. 296. A female torso, covered with drapery.

No. 297. 
ROOM Xv. No. 297. A piece of the shaft of a small Antrumites. Ionic column, the lower part of which is fluted and reeded.

No. 298. A Greek inscription, engraved on two sides of a large piece of marble. It is an inventory of the sacred treasures belonging to the Parthenon.

No. 299. A piece of the ceiling of the temple of Erech theus at Athens.

No. 299*. The lower part of a female statue covered with drapery.

No. 300. A bronze urn, very richly wrought. It was found inclosed within the marble vase in which it now stands, in a tumulus on the road that leads from Port Piræus to the Salaminian ferry and Eleusis. At the time of its discovery, this beautiful urn contained a quantity of burnt bones, a small vase of alabaster, and a wreath of myrtle in gold.

No. 301. A large marble vase; it is of an oval form, and within it was found the bronze urn described in the preceding number.

No. 302. A Greek inscription, engraved on two sides of a tablet of marble. It is a decree of the council of the Bœotians, ordaining the election of three extraordinary magistrates, who, in concert with the ordinary magistrates, were to take charge of the re-casting some articles of gold and silver, belonging to the temple of Amphiaraus, and which had been injured by the effects of time. 
No. 303. A piece of the shaft of a column, be- Room xv. longing to the temple of Erechtheus at Athens. Anrrqurres.

No. 304. A piece of the shaft of a column, also belonging to the temple of Erechtheus.

No. 305. A Greek inscription, engraved on two sides of a thick slab of marble. It is an inventory of the valuable articles which were kept in the Opisthodomos of the Parthenon, at Athens.

No. 306. An imperfect statue of a youth; it is of the size of life, and of the most exquisite workmanship.

No. 305*. A sepulchral column, of large dimensions; it is inscribed with the name of Aristides, who was the son of Lysimachus, and a native of Estiæa.

No. 306*. Part of the capital of an Ionic column.

No. 307. A circular altar, brought from the island of Delos. It is ornamented with the heads of bulls, from which festoons of fruit and flowers are suspended.

No. 308. A part of a Doric entablature, from the Propylæa at Athens.

No. 307\%. A female statue without head and arms, found in the temple of Themis at Rhamnus in Attica. Presented, in 1820, by John $P$. Gandy, Esq.

No. 308*. The capital of a Corinthian column.

No. 309. A Greek inscription, engraved on 
Roом Xv. three sides of a piece of marble. The characAntrquTties. ters are extremely ancient; but unfortunately the marble has been very much mutilated, and the letters defaced.

No. 310. The upper part of the shaft of a small Ionic column.

No. 311. A Greek inscription, engraved on two surfaces of a tablet of marble. It is an inventory of articles of gold and silver belonging to the Parthenon, and which the quæstors of the temple acknowledge that they have received from their predecessors.

No. 312. A piece of the shaft of an Ionic column, belonging to the temple of Erechtheus at Athens. 


\title{
REGULATIONS
}

\author{
CONCERNING
}

\section{T H E I N S P C T I O N}

OF THE

\section{BRITISH MUSEUM.}

The Museum is kept open for Public Inspection every Monday, Wednesday, and Friday in the week; except in the Christmas, Easter, and Whitsun-weeks; also, on the 30th of January, AshWednesday, Good Friday, the 5th of November, and any Fast or Thanksgiving Day that may occur; and likewise during the whole of the months of August and September.

Persons who may wish to see the Museum, are to apply in the ante-room of the house, between the hours of ten and troo, where their names, and the number of the friends they may wish to introduce with them, are inscribed in a book kept for the purpose: upon which, tickets will be delivered to them for the further admission. These tickets are to be exhibited on entering the first room on the upper floor, and to be delivered at the entrance of the Gallery of Antiquities.

It is expected that all persons who visit the Museum be decent and orderly in their appearance and behaviour; the officers being instructed 
instructed to refuse admission, or to cause to withdraw, any such as shall disregard this caution.

No children apparently under ten years of age will be admitted. Visitors are required to leave their canes and umbrellas on their first entrance into the Museum. 


\title{
DIRECTIONS
}

\author{
RESPECTING \\ THE READING ROOM \\ OF THE \\ BRITISH MUSEUM.
}

The Reading Room of the Museum is open from Ten till Four, every Day, except on Saturdays and Sundays, and for one Week at Christmas, Easter, and Whitsuntide; except also on the 30th of January, Ash-Wednesday, Good-Friday, 5th of November, and any Fast or Thanksgiving Days.

Persons desirous of Admission are to send in their Applications in writing (specifying their Christian and Surnames, Rank or Profession, and Places of Abode) to the Principal Librarian, co, in his Absence, to the Senior Under Librarian, who will either immediately admit such persons, or lay their Applications before the next General Meeting, or Committee of the Trustees. But as it might be dangerous, in so populous a Metropolis as London, to admit nerfect Strangers, it is expected that every Person roho applies should PRODUCE a Recommendation satisfactory to a Trustee or an Officer of the House. Applications defective in this respect will not be attended to.

Permission will in general be granted for Six Months; and at the Expiration of this Term, fresh Application is to be made for a Renewal. 
The Librarians are strictly enjoined to use all possible Despatch in supplying the Readers with the printed Books or Manuscripts they may apply for; but in so extensive a Library it may not be always possible to find every Article immediately.

Readers will be allowed to take one or more Extracts from any printed Book or Manuscript ; but no Whole, or greater Part, of a Manuscript is to be transcribed, without a particular Leave from the Trustees.-The Transcribers are not to lay the Paper, on which they write, on any Part of the Book or Manuscript they are using: nor are any Tracings allowed without particular Permission of the Trustees.

No Person is, on any Pretence whatever, to write on any Part of a printed Book or Manuscript belonging to the Museum; but if any one should observe a Defect in such Book or Manuscript, he is requested to signify the same to the Officer in waiting, who will make proper use of the Information.

It may be sufficient merely to suggest, that Silence is absolutely requisite in a Place dedicated to the Purposes of Study.

N. B. The Admission Tickets are by no means transferable; nor may Readers introduce Friends or Amanuenses roithout respective Tickets.

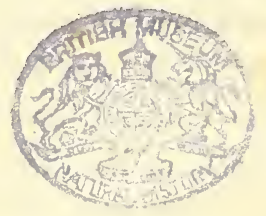

THE END.

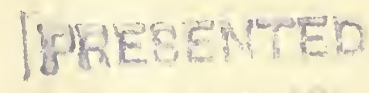







